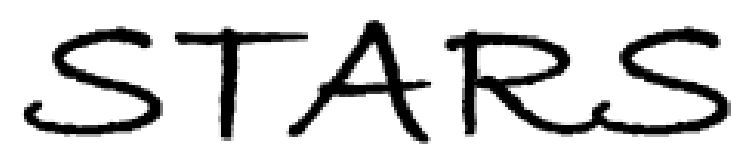

University of Central Florida

STARS

\title{
Letter from the Secretary of the Treasury
}

Find similar works at: https://stars.library.ucf.edu/cfm-texts

University of Central Florida Libraries http://library.ucf.edu

This Correspondence is brought to you for free and open access by the Central Florida Memory at STARS. It has been accepted for inclusion in Text Materials of Central Florida by an authorized administrator of STARS. For more information, please contact STARS@ucf.edu.

\section{Recommended Citation}

., "Letter from the Secretary of the Treasury" (1826). Text Materials of Central Florida. 117. https://stars.library.ucf.edu/cfm-texts/117

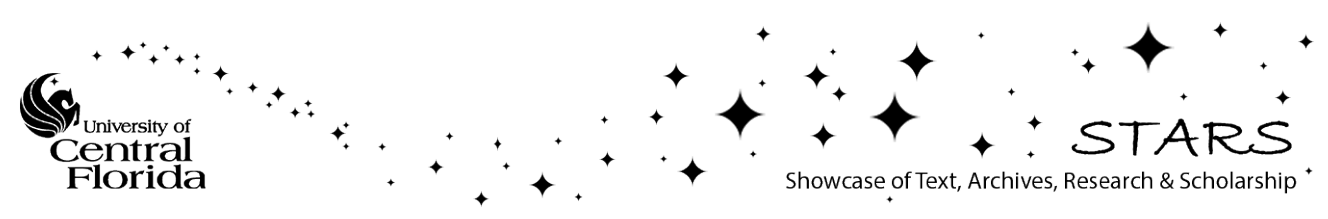


19th CONGRESS, 1st Session.

[Doc. No. 115.]

HO. OF REPS.

Treas. Dept.

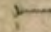

LAND CLAIMS IN EAST FLORIDA.

I

FROM

\section{THE SECRETARY OF THE TREASURY,}

\section{TRANSMITTING}

The information required by a resolution of the House of Representatives, of 7 th inst.

IN RELATION TO

\section{Cye Clatus to 7land in Fast florioa,}

WITH THE

General Report of the Commissioners of that District.

February 23, 1826.

Bead, and referred to the Committee on the Public Lands.

Ferruary 24, 1826.

Printed by order of the House of Representatives.

WASHINGTON:

PRISTED BY GALES Eै SEATOX:

1826. 

$\begin{array}{lll}\text { FL OR ID COLLE. } & 1 & 82-259088 \\ 975.9 & \text { U.S. TRE AS URY O }\end{array}$ UN I

LEITER FROM THE SEC 281521 RETARY DF THE TREAS

1. 281521 URY, TRANSMI T 15000

\section{ORLANDO PUBLIC LIBRARY SYSTE濡}

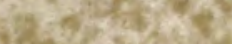

$\sin ^{2}$

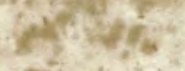

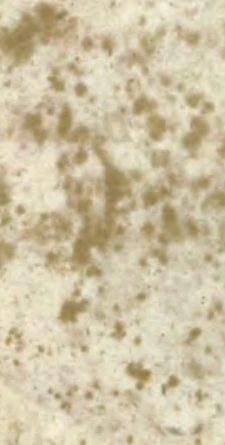

:

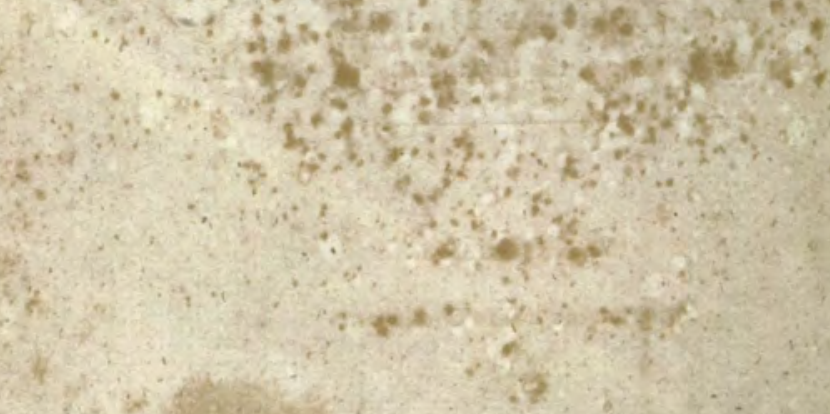

in 1 is:

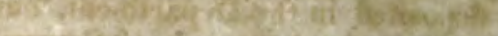

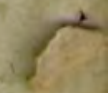




\section{Treasury Department,}

\section{February 21, 1826.}

SIR: In obedience to a resolution of the House of Representatives of the 7 th inst. directing the Secretary of the Treasury to communicate to the House copies of the Registers, or abstracts of the claims to lands in East Florida, lately deposited in this Department by the Commissioners of that District, under the quantity of three thousand five hundred acres, with the general report of said Commissioners, containing their reasons for the admission or rejection of the said claims, and full copies, with the evidence and decision of all claims over that quantity, which have been made, and lately deposited in the Treasury Department, I have the honor to transmit, herewith, copies of the following documents, to wit:

1. The abstracts of the decisions of the Commissioners, numbered from 1 to 10 , inclusive.

2. The evidence transmitted in cases exceeding 3,500 acres, referring to abstract No. 3, and numbered 1, 2, 3, 4, 5, 6, 7, 8, 9, 10, $11,12,19,20,21,22,23,25,26$.

3. The evidence numbered 11 , in the case of Francis P. Fatio, et al. lately deposited in the Department, but referring to abstract No. 5 , printed among the documents of Congress, with the report from this Department dated 21st February, 1825.

4. The reports of the Commissioners dated 1st January, 1826, and sist of the same month.

I have the honor to be,

With great respect,

Your most obedient servant.

RICHARD RUSH

The Hon. the Speaker

of the House of Representatives. 
21:pert No 1, Register of Claims to Lands, not exceeding three thousand five hundred acres of Land, which have been confirmed by the Commissioners for the District of East Florida.






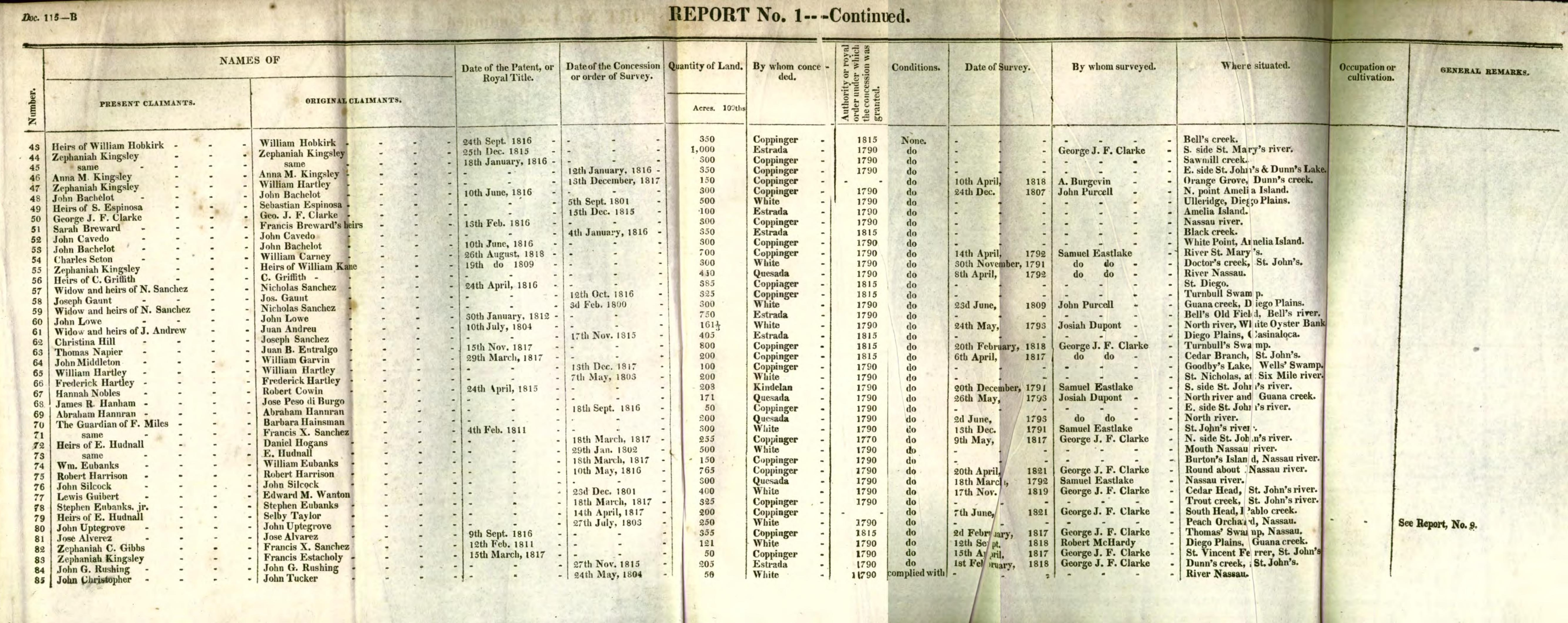



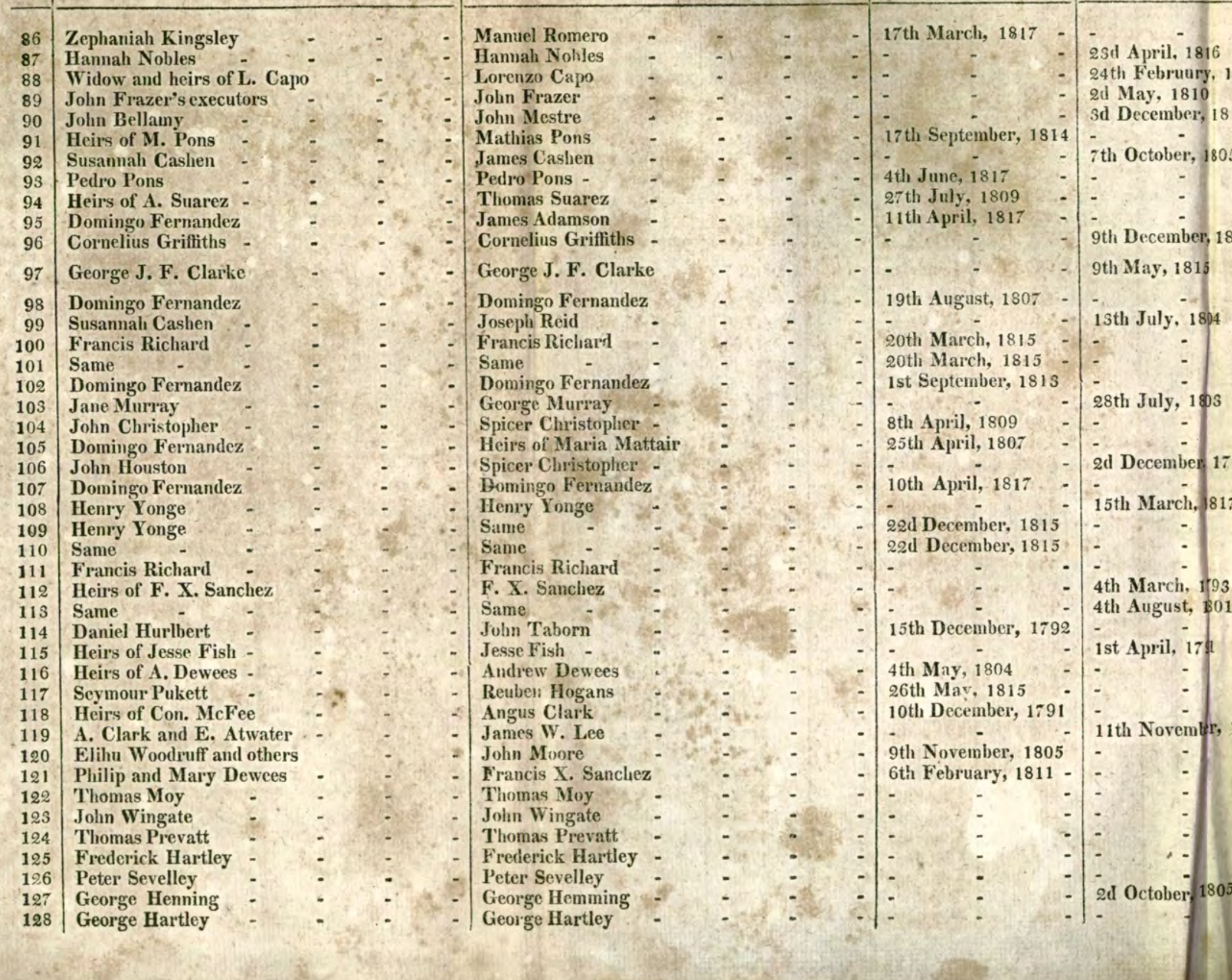

\begin{tabular}{|c|} 
Quantity of Land. B \\
\hline Acres. 100iths. \\
\hline 100
\end{tabular}
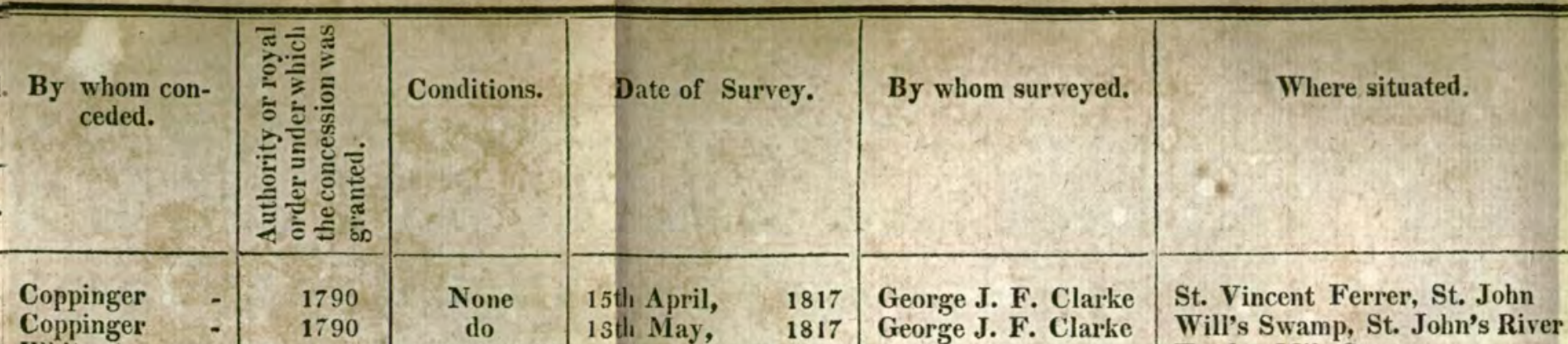

Black Point, Amelia
Amelia Iland

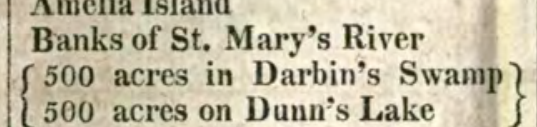

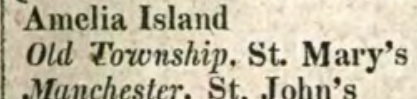

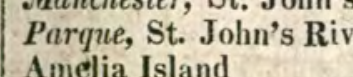

McDougall's Swam
Mouth of Nassau Ri Orange Grovere Ameliar

No.of Tathot tsland

Lest side Amelia
Lofton's Swamp

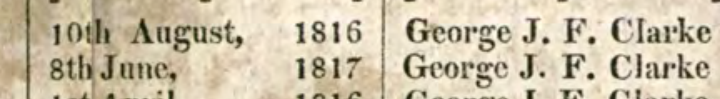

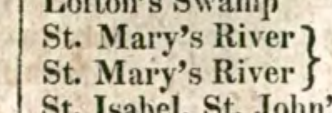

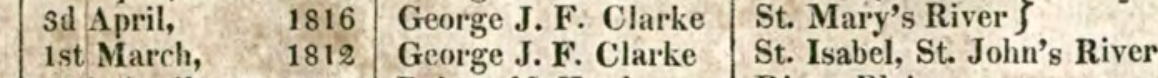
Same Sami 4 miles rom St. Angustine Graham 's Swamp
Pablo Crev, st. John's

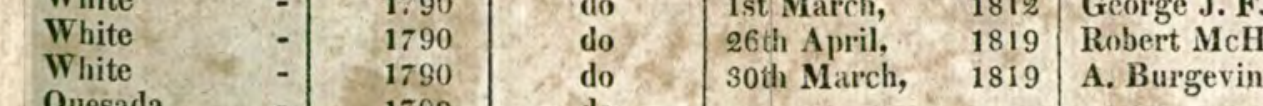

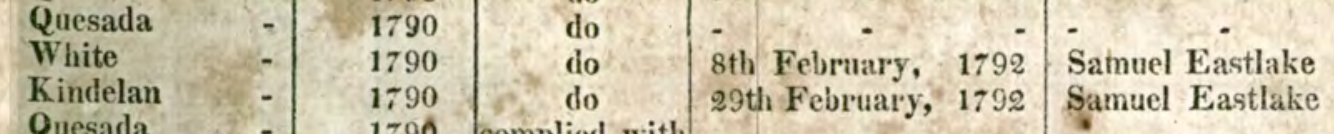

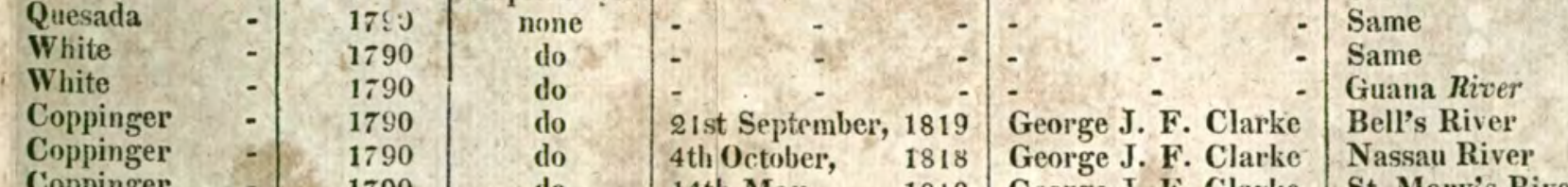


REPORT No. 1-Continued.




Doc. 115.-E.

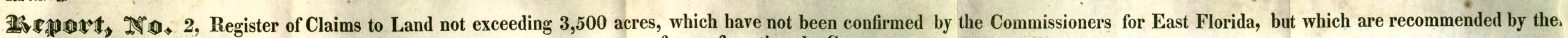
or confirmation, by Congress.

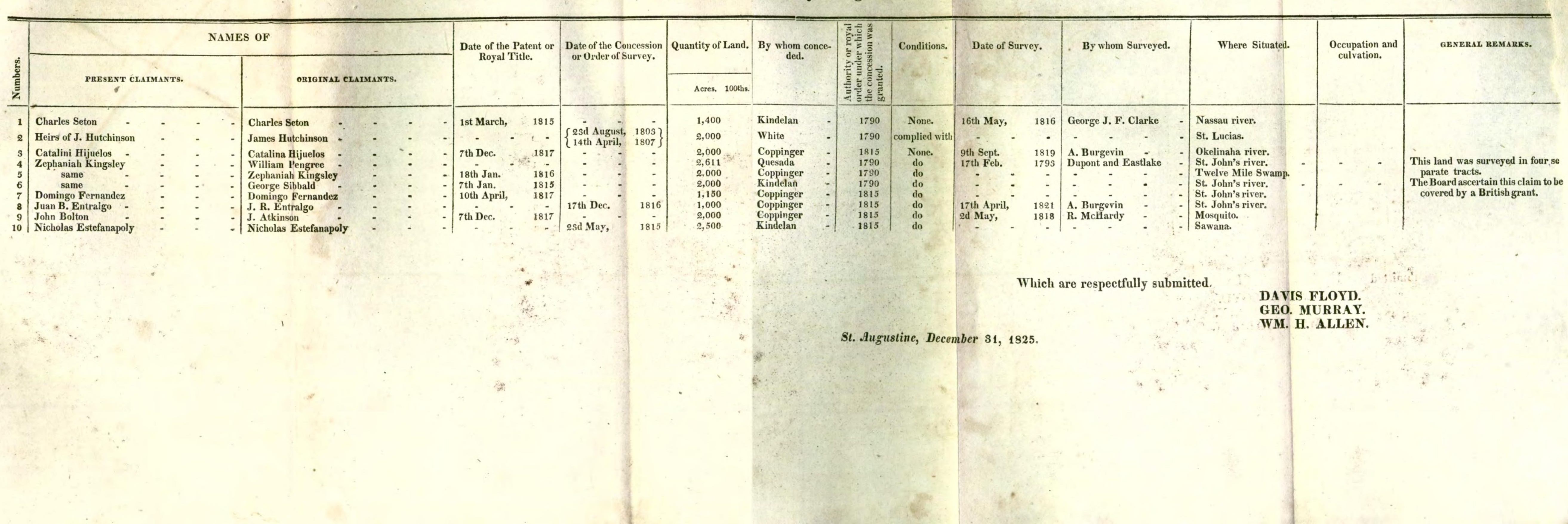




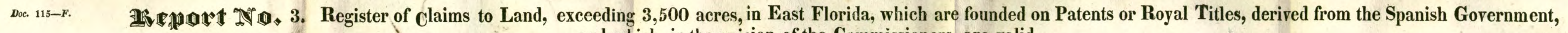
and which, in the opinion of the Commissioners, are valid.

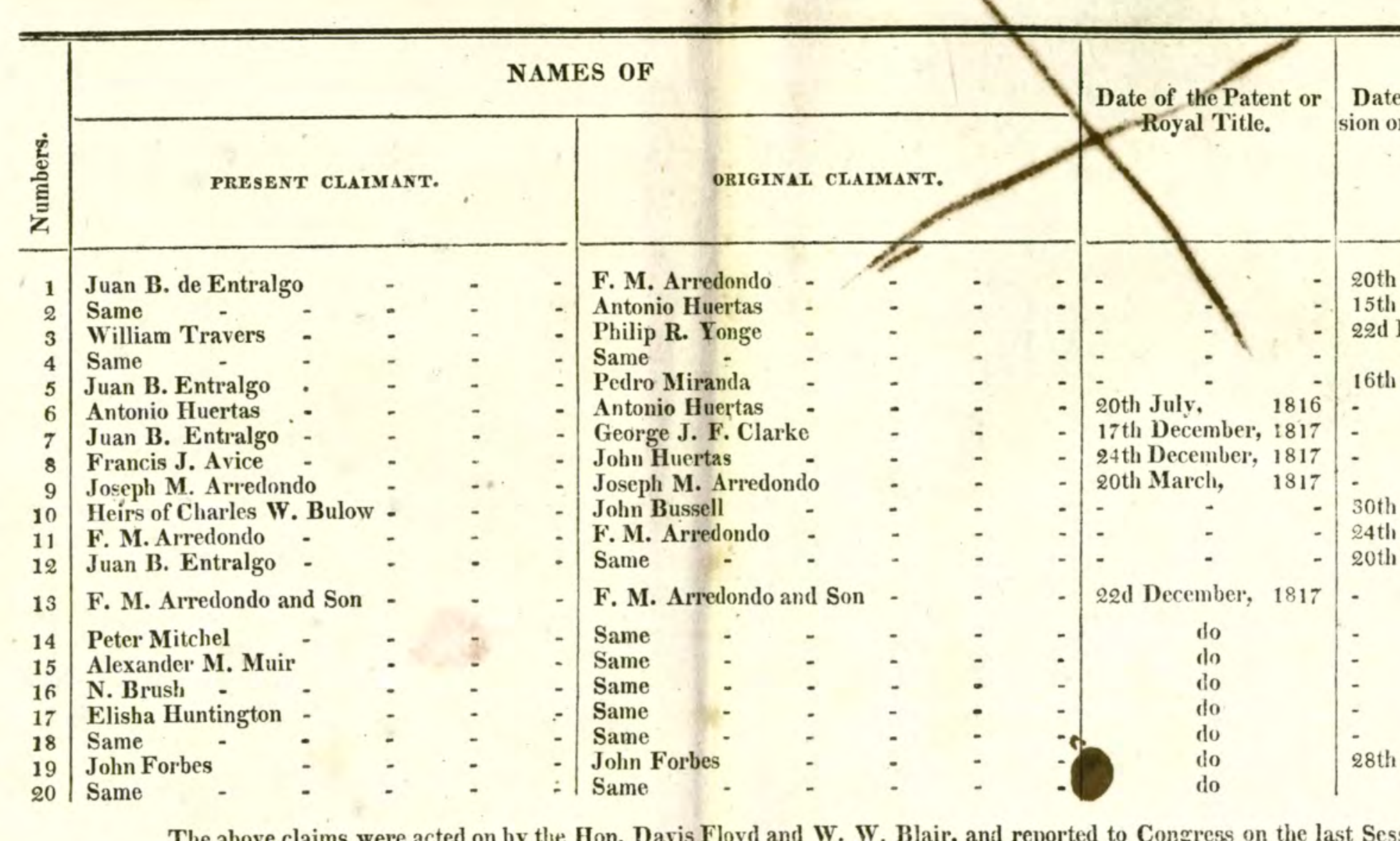

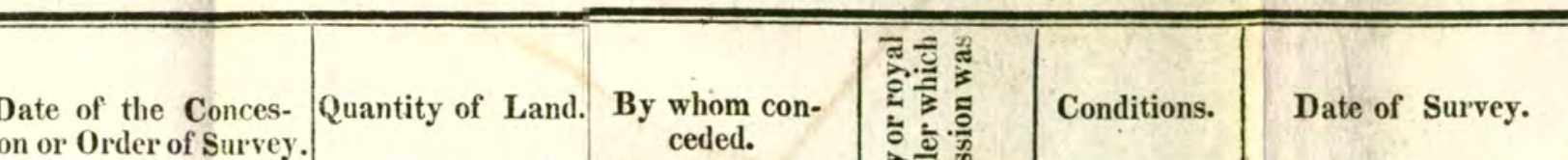

\begin{tabular}{|c|c|}
\hline By whom Surveyed. & Where situated. \\
\hline 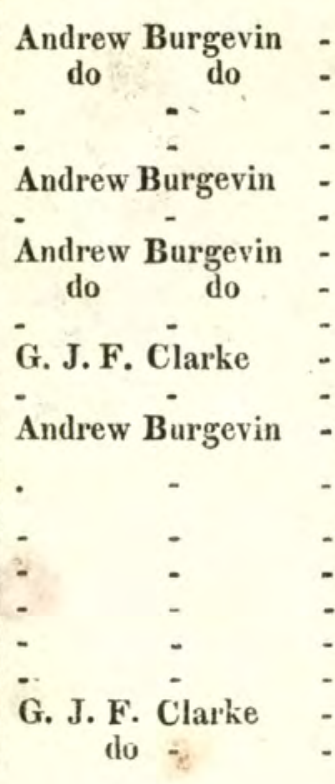 & 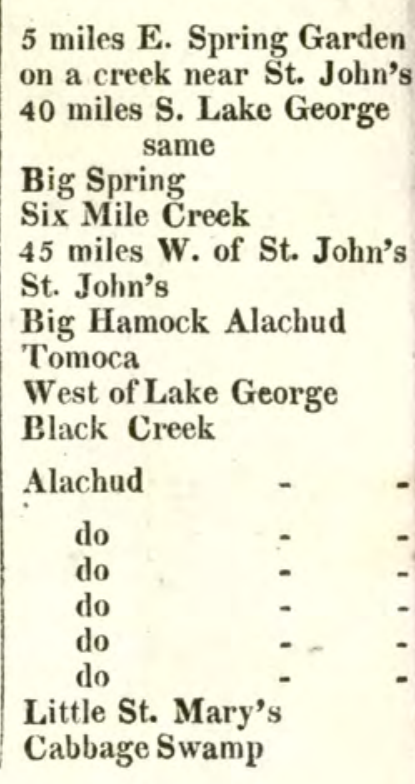 \\
\hline
\end{tabular}
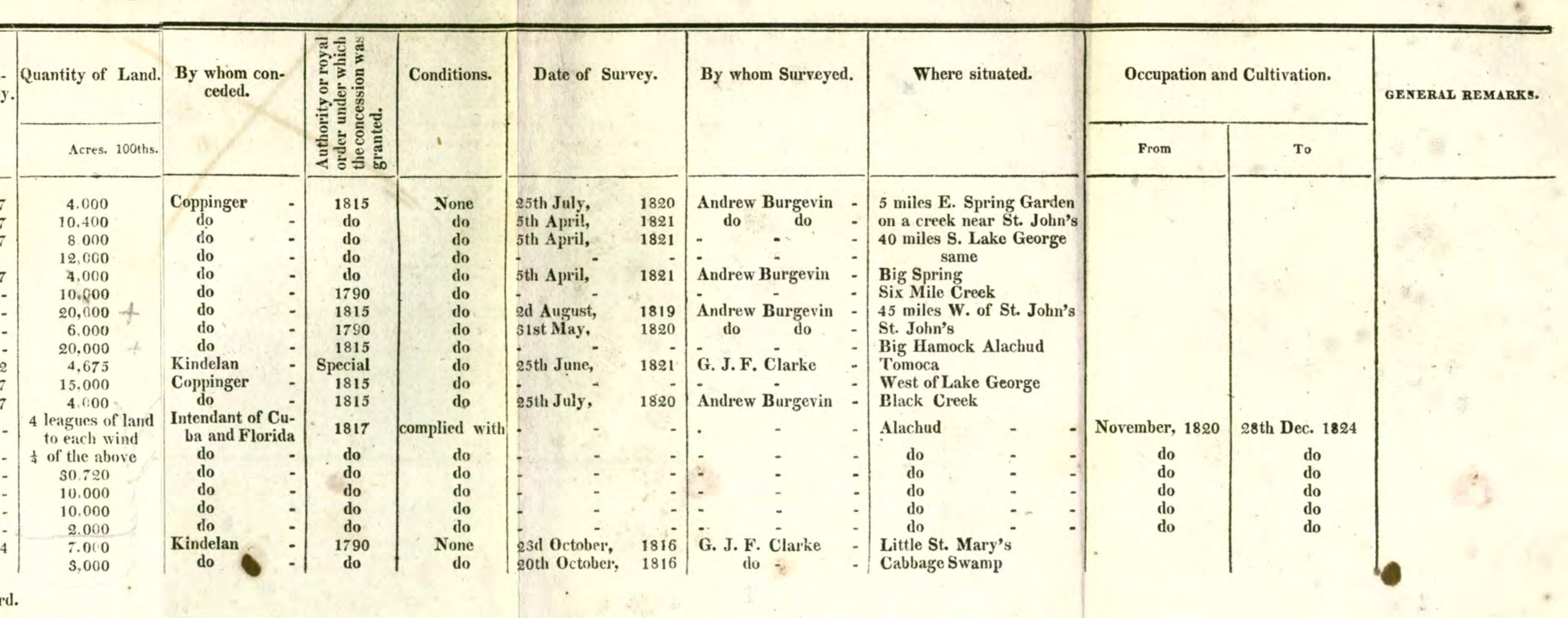

II

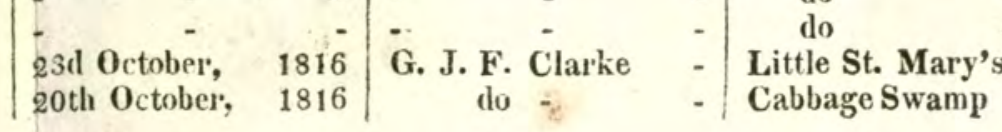

CASES REPORTED THIS SESSION. 
Doc. 115 -G

20upert No. 4. Register of Claims to Land, not exceeding 640 acres, founded on actual Inhabitation and Cultivation, previous to the $22 \mathrm{~d}$ February, $181 \mathrm{y}$, for which Certificates of Confirmation have been granted by the un'dersigned Commissioners.

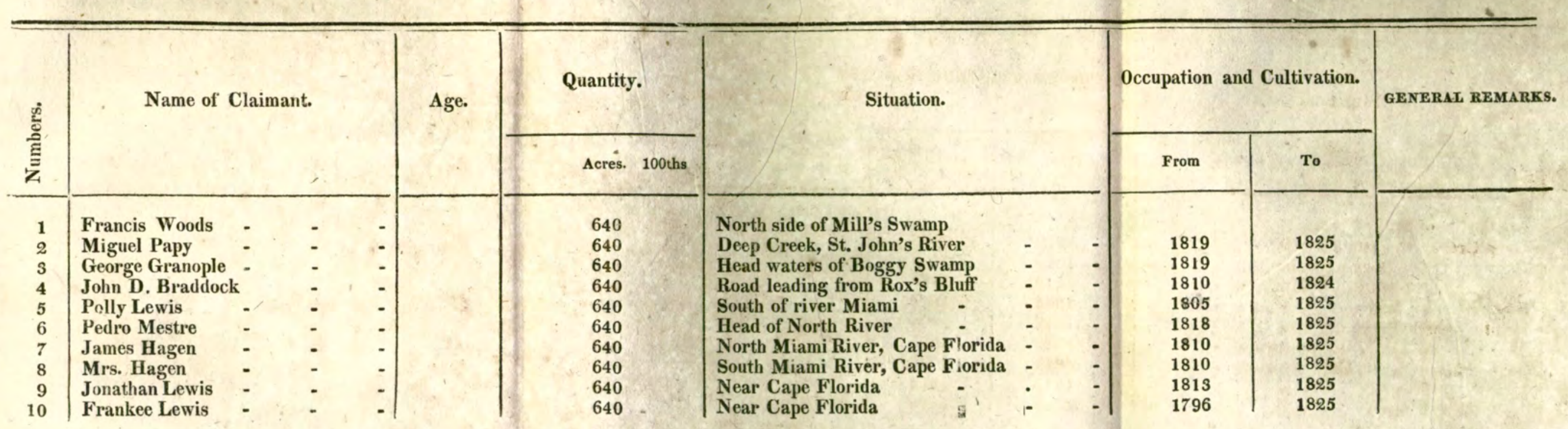

All which is respectfully submitted.

ST. AUGUSTINE, December 31, 1825.

DAVIS FLOYD.

GEO. MURRAY.

WM. H. ALLEN. 
Doc. 115-H

20.pert No. 5. Register of Claims to Land, not exceeding 640 acres, founded on actual inhabitation and cultivation, previous to 17 th July, 1821, which the Commissioners report to Congress for confirmation.

\begin{tabular}{|c|c|c|c|c|c|c|c|c|c|c|}
\hline \multirow{2}{*}{ 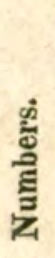 } & \multirow{2}{*}{\multicolumn{2}{|c|}{ Names of Claimants. }} & \multirow{2}{*}{ Age. } & \multicolumn{2}{|c|}{ Quantity. } & \multirow{2}{*}{\multicolumn{2}{|c|}{ Situation. }} & \multicolumn{2}{|c|}{$\begin{array}{l}\text { Occupation and } \\
\text { Cultivation. }\end{array}$} & \\
\hline & & & & Acres. & 100ths. & & & From & To & \\
\hline $\mathbf{1}$ & Dorcas Black & - & - & 640 & & On road leading to Jacksonville & & 1821 & 1825 & \\
\hline 2 & John R. Hogans - & - & - & 640 & & North side of River St. John's & - & 1820 & 1825 & \\
\hline 3 & Levi Sparkman - & - & - & 640 & - & Little Trout Creek - - & - & 1820 & 1825 & 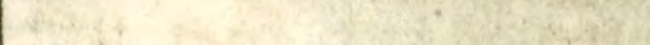 \\
\hline 4 & John D. Bladworth & - & - & 640 & & Dead Man's Swamp & - & 1820 & 1815 & $\therefore$ \\
\hline 5 & Heirs of John Carter & - & - & 640 & & South side of Trout Creek - & - & 1820 & 1825 & i \\
\hline 6 & Isaac Carter - & - & - & 640 & & Road from Jacksonville to Camp Pinkney & - & 1820 & 1825 & \\
\hline 7 & David Scurry & - & - & 640 & & N. side of St. John's River & - & 1819 & 1825 & $\begin{array}{l}\text { This claim has been rejected, but inserted } \\
\text { by mistake. }\end{array}$ \\
\hline 8 & John B rindley & - & - & 640 & & North side Black Creek & 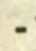 & 1819 & 1825 & \\
\hline 9 & John Oliver & - & - & 640 & & East side of Dunn's Lake - & - & 1818 & 1825 & - \\
\hline 10 & Jose Papy & - & - & 640 & & East side of Picolata Fort, St. John's & - & 1819 & 1825 & a? \\
\hline 11 & Andres Papy & - & - & 640 & & Twelve miles south of St. Augustine & - & 1819 & 1825 & 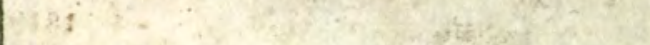 \\
\hline 12 & Henry Heartly - & - & - & 640 & & St. John's County - - & - & 1819 & 1825 & \\
\hline 13 & William Branning & - & - & 640 & & South side Black Creek & & 1817 & 1825 & \\
\hline
\end{tabular}

All of which is respectfully snbmitted.

ST. AUGUSTiNe, December 31, 1825.

DAVIS FLOYD.

GEO. MURRAY.

WM. H. ALLEN. 
Doc, 115, - I.

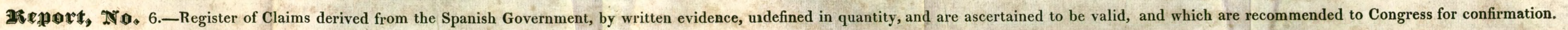

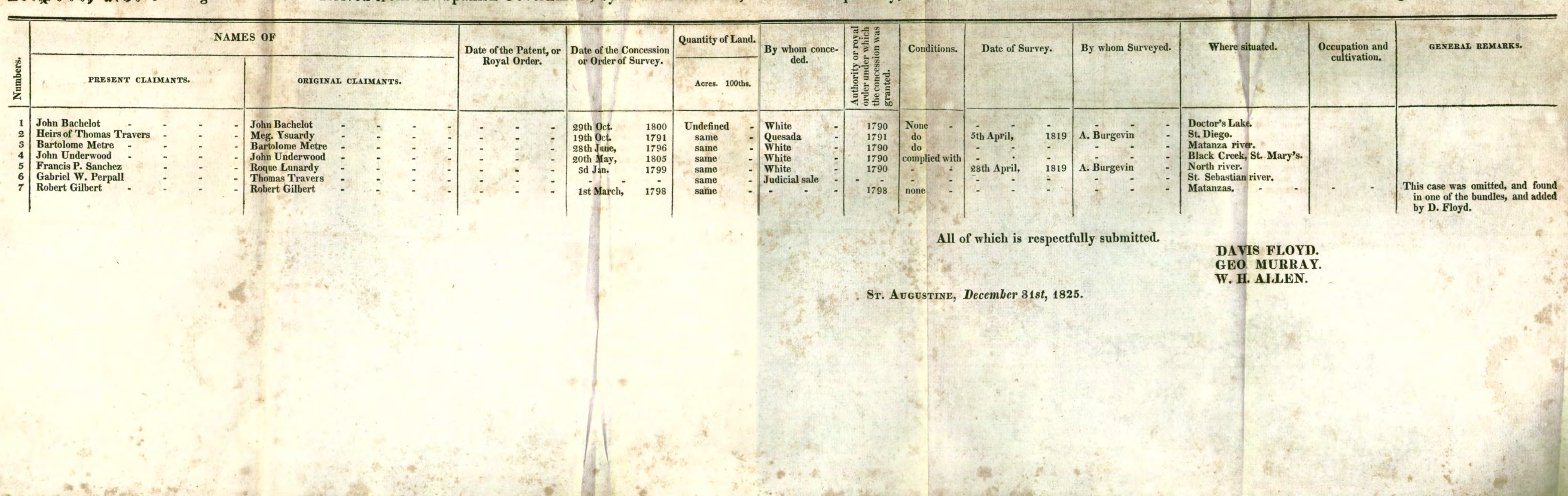




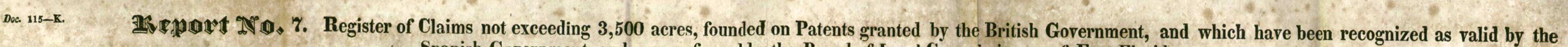

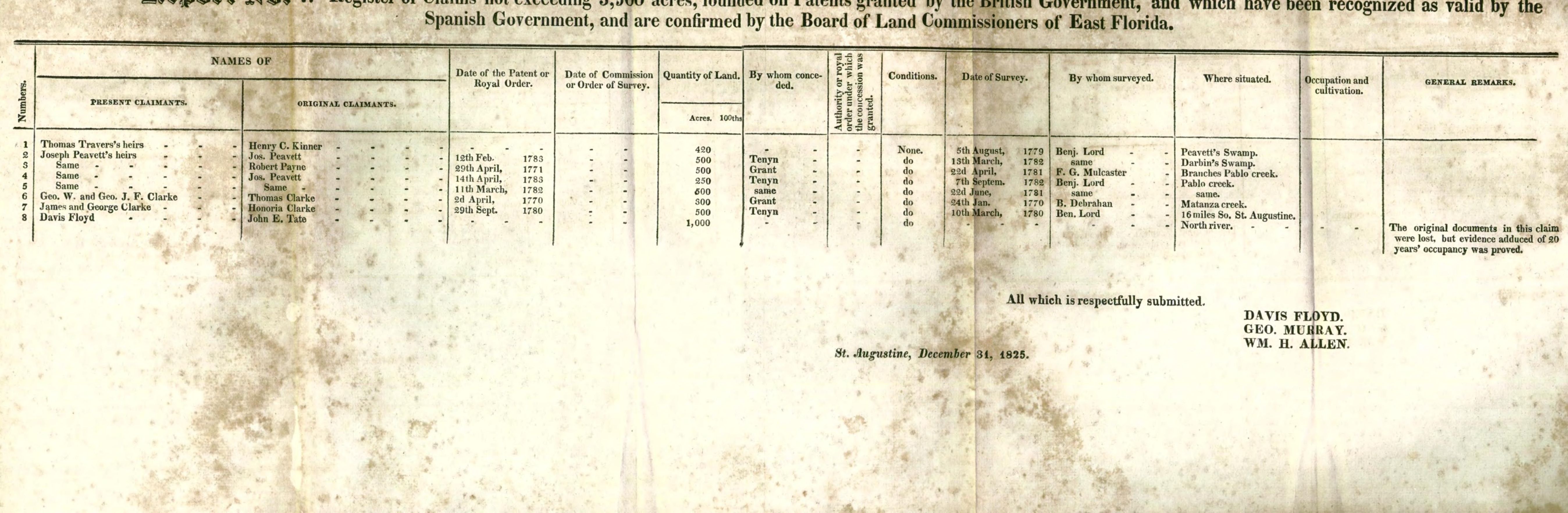




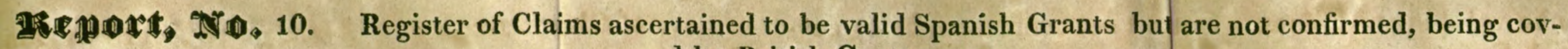
ered by British Grants.

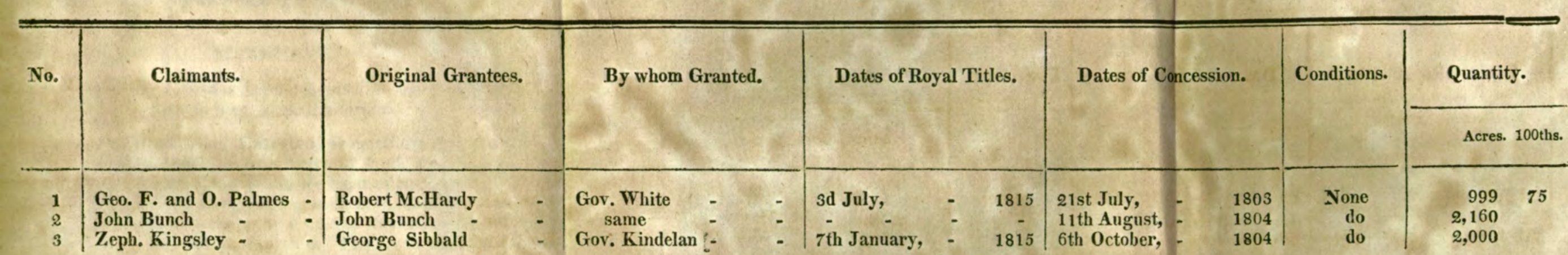

All of which is respectfully submitted.

DAVIS FLOYD.

WM. H. AILLEN.

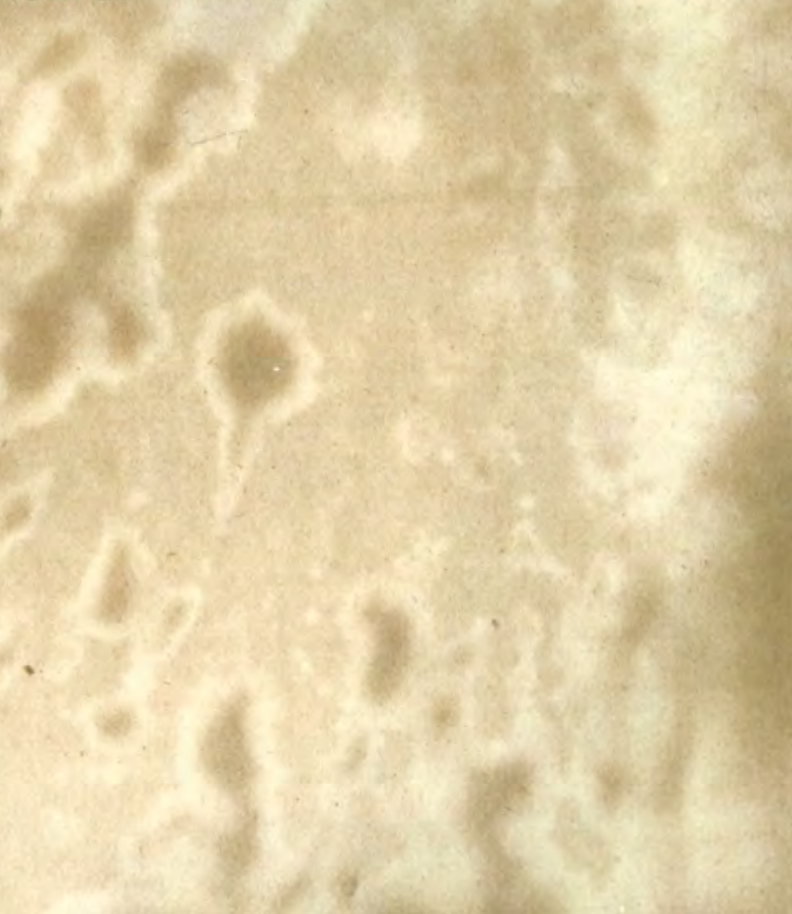


No. 1.

$\left.\begin{array}{c}\text { Juan Blas Entralgo, } \\ \text { vs. } \\ \text { The United States, }\end{array}\right\}$ For 4,000 Acres of Land.

MEMORIAL.

To the Honorable the Commissioners appointed to ascertain claims and titles to land in East Florida:

The petition of Juan Blas Entralgo, respectfully sheweth: That your memorialist claims title to a tract of land, consisting of four thousand acres, situated about five miles East of Spring Garden, and bounded as follows: beginning at the head of a mountain, and running South $60^{\circ} \mathrm{W}$ est, 100 chains to a stake; thence, South $30^{\circ}$ East, 105 chains to a stake; thence, North $60^{\circ}$ East, 235 chains 20 links, to a pine, marked =; thence, North $30^{\circ}$ West. 220 chains to a pine, marked ++; thence, South $60^{\circ}$ West, $1 S 5$ chains 20 links to a stake; thence, South $30^{\circ}$ East, 115 chains to the beginning; which title your memorialist derives from a grant made to F. M. Arredondo, by Governor Coppinger, in virtue of the Royal order of 1815, who sold the same to your memorialist, as will appear by document $\mathbf{A}$, which, together with the grant to Arredondo, marked B, is herewith filed. And your memorialist further sheweth, that he has legal possession of said lands, and that he was a Spanish subject, living in St. Augustine at the change of Government in 1821, and that he now resides in the Havana. In consideration of what is herein set forth, he prays, his titie to the said four thousand acres may be confirmed.

J. B. ENTRALGO,

$$
\text { By }
$$

GEORGE MURRAY, Attorney. for Memorialist.

\section{TRANSLATION.}

Senor Governor: Don Fernando de la Maza Arredondo. Jun. inhabitant of this city, with due respect. states to your Excellency, that, from the beginning of the insurrection of the year 1812 , he took up arms and acted as Commandant of a party of cavalry to reconnoitre the enemy, one of whom he took prisoner afterwards, when they presented themselves in sight of this city; and, afterwards, the memorialist continued performing service in the militia, and patrolling at night, when necessary for the guard and defence of this ciry, without pay, rations, or any emolument; at which time he performed other important services for the Government: among others, provision of meat, and victuals for the support of the garrison, all of which is known to your Excellency; and as his Majesty, in his royal order of the 29th Mlarch, 1815, has deigned to reward, witlı a distribution of land, the faithful inhabitants who contributed to the defence of this province, the memorialist being one of them, and, as is more fully ex- 
pressed, one of those whom the laws and royal dispositions regard with attention, distinguishing the merit and quality of the services, as besides all the other circumstances which concur, it is also a very powerful one, that he is a native of the country, established in it with more than eiglity negroes of his property. Wherefore he prays your Excellency to be pleased to grant him, in absolute property, 10,000 acres of land, situated to wit: 5,000 acres of them on a hammoc which is about five or six miles to the East of Spring Garden, and the other 5,000 to the West of the river St. John, in the neighborhood of a creek known as Black creek, near Flemingo Island, and the lake near Doctor's Lake, titles of dominion to which to be made out and delivered, as soon as the Surveyor accomplishes the survey and laying off of both tracts of land; and that the corresponding plats are formed, which shall designate and mark out perfectly the situation and boundaries: a favor which he hopes for from the justice of your Excellency.

FERNANDO DE LA MAZA ARREDONDO.

St. Augustine, Florida, 18 th of March, 1817.

St. Augustine, 20th March, 1817.

In virtue of the services which Don Fernando de la Maza Arredondo has performed, and alleges, which are certain and notorious, and using the authority which I exercise, agreeably to the intentions and desires of his Majesty, to reward his faithful subjects, which the laws recommend in similar cases, and considering the large number of slaves he possesses, $I$ bave granted as in the name of his Majesty and his royal justice which I administer, I do grant, in absolute property, and with a title of dominion from this day and henceforward, to the said Don Fernando de la Maza Arredondo, the 10.000 acres of land in the places he solicits, without injury to a third person, for which the corresponding titles of property shall be issued as soon as the survey and laying off are performed by the Surveyor; this decree, in the meanwhile, serving for an equivalent, which, with the proceedings, shall be filed in the Notary's office, giving to the interested an authenticated copy for his security.

Before me,

COPPINGER.

JUAN DE ENTRALGO, Notary of Government.

I certify the foregoing to be a true and correct translation from a document in the Spanish language, on file in the office of the Public Archives of St. Augustine.

F. J. FATIO, S. B. L.C. 


\section{[TRANSLATION.]}

Conveyance.

Be it known that I, Don Fernando de la Maza Arredondo, Jun. inhabitant of this province, declare that I really sell to Juan de Entralgo, Notary of Government and the Royal Domain in this city, four thousand acres of land, which I hold as my property in this province, situated about five miles to the East of Spring Garden, known under the following dimensions: the first line begins at the head of a hammoc, and runs South $60^{\circ}$ West, measures one hundred chains, and ends with a stake; the second runs South $30^{\circ}$ East, contains one hundred and five chains, and ends also with a stake; the third line runs North $60^{\circ}$ East, measures two hundred and thirty-five chains, twenty links, and ends with a pine marked $=$; the fourth line runs North $30^{\circ}$ West, measures two hundred and twenty chains, and ends with a pine marked ++ ; the fifth line runs South $60^{\circ}$ West, measures one hundred and thirty five chains, twenty links, and ends with a stake; the sixth line runs South $50^{\circ}$ East, measures one hundred and fifteen chains, and ends at the head of the said hammoc; which four thousand acres of land, with a portion more, this Government granted me in absolute property and dominion, as a reward for services, on the 20th of March, 1817, and the corresponding title was issued to me on the 9th of August, of the last year, as all appear in the archives of the said Notary. And I sell the said four thousand acres of land, under the dimensions and other things which are explained, with all its entrances, outlets, uses, customs, rights, and services, which it has had, has, and belong, or may appertain to it, free of all incumbrance, at the price of $\$ 4,000$, which the purchaser has paid me in cash, which sum I acknowledge as delivered to my will. I renounce proof, laws of delivery, exception to money not counted fraud, and every thing else, in the case; for which I grant a receipt in form, in virtue of which I separate myself from the right of property, possession, use, seigniory, and otlier rights, real and personal, which I had or held to said lands; and I cede, renounce, and transfer them to the purchaser, and whoever shall represent his right, that they may possess, sell, and alienate them at their will, in virtue of this deed, which I deliver in his favor, as a mark of real delivery, from which it is seen that he has acquired the possession, without occasion for other proof, from which I release him; and I oblige myself to the eviction and guarantee of this sale in suflicient form, and as may best suit in favor of the purchaser, with my goods, present and future, power and submission, to the tribunals of H. M., that they may force me to compliance, as by sentence consented to and passed in authority of an adjudged case, on which I renounce all the laws, customs, rights, and privileges in my favor, and formal exceptions which prohibit it. And I, the said Juan de Entralgo, being present, accept, in my favor, this deed, and by it receive, as purchased, the aforesaid four thousand acres of land, at the price and agreement upon which thay were sold to me, and $I$ acknowledge them as delivered 
to my will. I renounce proof, laws of delivery, those of a thing not seen or received, fraud, and every thing else, in the case, for which I grant a receipt in for'm. In testimony of which, this is dated in the city of St. Augustine, Florida, the 5 th of January, 1821.

I, Don Jose Coppinger. Colonel of the royal armies, Military Governor, Political Chief, and sub-Delegate of ultra marine possessions for this said city and province. certify. that I know the parties who have granted, delivered, and signed in my presence, and in that of the assistant witnesses. whom I have chosen for this act, Don Tomas de Aguilar, and Don Antonio Alvarez, there being no wther Notary in the entire province, there being witnesses to this deed, Don Jose Mariano Hernandez, Don Bernardo Segui, and Don Jose Bernado Reges: residents present, Coppinger, Fernando M. Arredondo, Juan de Entralgo, Tomas de Aguilar, Antonio Alvarez.

Tt:is is conformable to the original which exists in the archives of the said Government Notary, to which I refer, and at the desire of the parties sign the present copy, with the assistant witnesses, on two leaves of common paper, the stamped not being in use.

JOSE COPPI VGER,

Tomas De Aguilar. ANTONIO ALVAREZ.

St. Augustine, Florida, 5th Jan. 1821.

I certify the foregoing to be a true and correct translation from a document in the Spanish language, on file in the oflice of the public archives of St. Augustine.

F. J. FATIO, S. B. L. C.

TRANSLATION.

Don Andres Burgevin of this place and private Surveyor.

I certify, that, by an order of this Governor, made the 20th of August, 1819, I have measured in favor of Don Fernando de la Maza Arredondo, jun. a piece of land which contains 4000 acres of land, which is five miles to the east of Spring Gardens, being part of a greater quantity which was granted to him on the 20th of March, 1817. in proof of which $I$ give these presents, which $I$ sign at St. Augustine, Florida, the 25 th of July, 1820.

ANDRES BURGEVIN.

[Here follows the Plat.]

I certify the foregoing to be a true and correct translation from a document in the Spanish language on file in the office of the public archives of St. Augustine. 


\section{DECREE.}

Juan $B$. de Entralgo.?

The United States. $\}$

For 4,000 acres of land.

The Board having ascertained the above to be a valid Spanish concession, made to F. M. Arredondo, previous to the 24th of January, 1818 , who conveyed the above 4.000 acres to claimant, do therefore recommend it to Congress for confirmation.

12 th July, 1824.

No. 2 .

Juan B. Entralgo,

The United States. $\}$ For 10,400 acres of land.

\section{MEMORIAL.}

To the Hon. the Commisioners appointed to ascertain claims and title to lands in East Florida.

The petition of Juan B. Entralgo respectfully sheweth: That your memorialist claims title to a tract of land, consisting of ten thousand four hundred acres, situated on St. John's river to the west, and about 12 miles south of Lake George, bounded as follows, commencing at a pine marked thus $=$, running $\mathrm{S}, 20^{\circ}$ E. 322 chains, to a pine tree marked as the first ; thence, N. $70^{\circ} \mathrm{W}$. 323 chains, to a pine, same mark ; thence, N. $20^{\circ}$ E. 322 chains, to a pine with the same mark; thence, S. $70^{\circ}$ E. 323 chains, to the beginning. This tract is nearly equally divided by a stream running from the West into St. John's river. Which title your memorialist derives from a grant made to Antonio Huertas by Governor Coppinger, in virtue of the Royal order of 29th March, 1815, who sold the same to your memorialist on the 4 th December, 1821. The concession was made the 15th September, 1817, (See a certified copy of the document filed herewith, as is also a p!at of the land). And your memorialist further sheweth, that he is in possession of said lands; that he resides in Cuba, but at the change of flags was in Augustine.

JUAN B. ENTRALGO, by GEORGE MURRAY.

\section{TRANSLATION.}

Senor Governor: Don Antonio Huertas, an inhabitant of this city, with due respect, states to your excellency, that, although he has obtained a concession of 10,000 acres of land on the 27 th of March, 
1813 , for the pasture of cattle, in the rearing of which this party has employed himself for many years; as the said land is almost all composed of pine land and very little arable, and the memorialist being one of the individuals who, by his well known and constant good services in defence of this province, and by his having been one of the first settlers of it, is entitied by every claim to be rewarded with a greater number of acres as the laws so provide, which treat in the matter, as from the character of his services, which he omits stating, as they are well known to your excellency, not only those which he has performed in the service of H. M. on which he has been employed since the age of 18 years, but the extraordinary ones of succoring the garrison of this city in calamitous times. and in the insurrection, making a sacrifice of his interests, and encountering perils, by the help of which lie can say, he has preserved the garrison. Wherefore he prays your excellency, to be pleased to grant him 15,000 acres of land more, in absolute property and dominion; on a creek which comes frem the West and joins in the river St. John's, about 12 miles to the South of Lake St. George, its survey to commence about 4 or 5 miles to the West of the river St. John's, and diriding the said lands in two parts by said creek, reserving the delivery of the title in form, until the memorialist finds it convenient to proceed to the survey and dernarcation of said land by an intelligent person, during the difficulties which exist at this day, and from the absence of the Surveyor, Don George Clarke, who is named by the Governor; a favor which he hopes for from the justice of your excellency.

ANTONIO HUERTAS.

St. Augustine, Florida, 15th Sept. 1817.

\section{St. Augustine, 15th Sept. 1817.}

In attention to what this party represents, and the services which he sets forth being certain, I grant him, in the name of His Majesty, and of his royal justice, which I administer, the 15,000 acres of land which he solicits that he may possess and enjoy it in absolute property and dominion : and, in order to make this grant secure, let a certified copy be furnished him of this proceeding, which shall be lodged in the archives of the Notary, where titles in form shall be issued when the survey and plats are accomplished, as is expressed by the interested.

\section{COPPINGER.}

I certify the foregoing to be a true and correct translation from a document in the Spanish language, on file in the office of the public archives of St. Augustine.

$$
\text { F. J. FATIO, S. B. L. C. }
$$


TRANSLATION.

Don Andres Burgevin, inhabitant of this City, and Private Surveyor.

I certify, that in virtue of authority conferred on me, by a decree of the 13 th of December, 1820, made at the instance of Don Antonio Huertas, I have surveyed for this individual several pieces of land, which, to the number of 15,000 acres were granted him as a reward for services, on a creek which comes from the West and joins the river. St. John's, about 12 miles to the South of Lake St. George, the land divided by said creek, one of said tracts being 10,400 acres, which are bounded on the East by another of 600, and on the other sides by vacant lands, whose figure and demarcation the foregoing plat points out, and for its confirmation and the purposes convenient to the interested, I sign these presents.

St. Angustine, Florida, 5th April, 1821.

\section{ANDRES BURGEVIN.}

[The plat follows.]

I certify the foregoing to be a true and correct translation from a document in the Spanish language, on file in the office of the public archives of St. Augustine.

$$
\text { F. J. FATIO, S. B. L. C. }
$$

No. 2-R.

[TRANSLATION.]

I cede and renounce in favor of Don Juan Blas de Entralgo, all the right, title, and dominion, which $I$ have to the 10,400 acres of land, contained in this document of property, on account of having sold him the same for the sum of $\$ 5,000$, for which I deliver him a formal receipt.

\section{Witness-Domingo ReYes.}

ANTONIO HUERTAS.

I certify the foregoing to be a true and correct translation from a document in the Spanish language.

F. J. FATIO, S. B. L. C.

\section{Decree.}

The Board having ascertained the above to be a valid Spanish concession, made previous to the 24 th of January, 1818, do, therefore recommend it to Congress for confirmation.

June 30 th, 1824. 
John B. De Entralgo The United States. $\}$

For 10,400 acres of land.

B. Segui, being duly sworn, states that he has seen Antonio Huertas write, and believes that the name attached to the conveyance from said Huertas to Entralgo, to be his own hand writing, but is not positive. Witness states that, after the cession of this Territory, and the archives taken away from the Spanish Notary, it was customary for some person to have conveyances drawn out in the manner of the one presented in the above case.

Before the Board in session, June 29th, 1824.

B. SEGUi.

Jose B. Reyes, being duly sworn, states that the signature of Antonio Huertas, in the deed to John B. Entralgo, to be the genuine one of said party.

Before the Board in session, June 30th, 1824.

JOSE B. REYES.

No. s. $R$.

$\left.\begin{array}{c}\text { Wm. Jravers } \\ \text { vs. } \\ \text { The United States. }\end{array}\right\}$ For 8,000 acres of land.

\section{MEMORIAL.}

To the Honorable the Commissioners appointed to ascertain claims and titles to lands in East Florida:

The petition of $\mathrm{Wm}$. Travers respectfully sheweth: that your memorialist claims title to a tract of land consisting of 8,000 acres, situated on the West side of Long Lake, on the West side of St. John's river, about forty miles South of lake George, bounded as follows: first line runs South, and is bounded by lants of Felipe R. Yonge; thence, West one hundred and forty chains; thence, South, eight chains; thence, West two hundred and fifteen chains, and terminates at a pine tree; thence, North two hundred and forty chains, to a cypress tree; which title your memorialist derives from an absolute grant made to Felipe R. Younge, by Governor Coppinger, in virtue of the royal order of 29th March, 1815, who sold the same to your memorialist. A certified copy of the grant, which was made the 22d February, 1817, is filed herewith. And your memorialist further sheweth that he has pessession of said lands; that he resided in Augustine, at the change of flags, and still does so; that he is a citizen of the United States, and resident of St. Augustine.

WM. TRAVERS. 
Translation of royal title to P. R. Yonge for 25,000 acres, is filed in claim of William Travers for 12,000 recommended for confirmation on the 12th of July, 1824.

Power of attorney from Philip R. Younge to Juan B. Entralgo, is Bled in the aforesaid claim.

[TRANSLATION.]

\section{Conveyance.}

Be it known that I, Don Juan de Entralgo, Notary of Government and of the public domain in this city, as attorney of Don Philip R. Yonge, citizen of this province, now absent, which power he has conferred on me in this office, on the 29th of May, 1819, before Senor Don Jose Coppinger, Colonel of the national armies, Military Governor, and Political Chief of this province, and before witnesses assisting for want of another Notary in the province, which power is not revoked, and is ample for what shall be said; in virtue of which I also have an order or instruction in writing, from the said principal, and of the same date for the purpose, I declare that I really sell to Don William Travers, an inhabitant and merchant of this city, 8,000 acres of land, the property of my said principal, situated on the West side of the Long Lake, distant about forty five miles to the South of lake George, to the West of the river St. John, which are a part of 13,000 acres which, under date of the 11th of February, 1817, were granted by this Government to the said Don Philip Robert Yonge, in absolute property and dominion, as a reward for his services, and for which a corresponding title was issued on the $22 \mathrm{~d}$ of the same month, the plat and survey of which made, by the private Surveyor, Don Andrew Burgevin, on the $2 \mathrm{~d}$ of August, 1819, with the other documents referred to, and which, from the proceedings existing in my archives, the said dimensions being known under the following form: the first line runs South, bounding the 5,000 acres remaining to the persons who empower me; the second line West, measures one hundred and forty chains; the third line South eight chains; the fourth line West two hundred and fifteen chains, and terminates with a pine tree; the fifth line North two hundred and forty cbains, beginning with said pine, and terminating with a cypress, as appears by another plat made by said Surveyor on the 22d of May last, in consequence of superior order; all which is added to the sail proceedings; and I sell him the said 8,000 acres of land at the place, under the dimensions and on the terms set forth, with all its entrances, outlets, uses, customs, rights, and services, which it has, and belong to it, free of all incumbrance, (as I, the seller, certify, as appears from the book of mortgages in my charge, which $I$ have searched for the purpose,) at the price of $\$ 8,000$, which the purchaser has paid me in cash, which sum I acknowledge as delivered to my will. I reneunce proof laws, of delivery, exception to money not counted, fraud, and every thing else in the case, for which I grant a formal receipt, in 
virtue of which I separate the said Don Philip R. Yonge from the right of property, possession, use, seigniory, and other rights, real or personal, which he had or held to the said 8,000 acres of land; and that I cede, renounce, and transfer them to the said Don William Travers, and whoever represents his rights, that they may, as their own, possess, sell, and alienate them at their will, in virtue of this writing, which I deliver in his favor as a mark of real delivery, by which it may be seen that he has acquired the possession without occasion for further proof, from which I relieve him. And I oblige the said Don Philip R. Yonge to the eviction and guarantee of this sale, in sufficient form and as may best suit in favor of the purchaser, with all his property, present and future, power and submission. to the tribunals of his Majesty, that may compel me to compliance with it, as by sentence consented to, and passed in authority of an adjudged case. Moreover, I renounce ail the laws, custonis, rights, and priveleges in his favor, and every thing in form which prohibits it. And I, the aforesaid Don William Travers, being present, accept, in my favor, this writing, and by it receive as purchased, the said 8,000 acres at the price and terms they were sold to me on; and I acknowledge them as delivered to my will. I renounce proof, laws of delivery, those of a thing not seen or received, fraud, and all other things in the case, for which I deliver a formal receipt. In testimony of which, this is dated in the city of St. Augustine, Florida, the $22 d$ of December, 1820. I, the Notary, as the only one in this city, and as the seller, sign this writing for myself, and before me, with the purchaser, and the witnesses who are Don Pedro Miranda, Don Jose Mariano Hernandez, and Don Fernando M. Arredondo, Jun., inhabitants present. By me and for myself,

\section{JUAN DE ENTRALGO, WM. TRAVERS.}

This is conformable to the original, which exists in the archives in my charge, to which I refer, and at the desire of the party, sign and seal these presents in St. Augustine, Florida, the day of the date.

\section{JUAN DE ENTRALGO,} Notary of Government.

I certify the foregoing to be a true and correct translation from a document in the Spanish language, on file in the office of the public . archives of St. Augustine.

$$
\text { F. J. FATIO, S. B. L. C. }
$$

\section{DECREE.}

\section{$\left.\begin{array}{l}\text { Win. Travers, } \\ \text { vs. } \\ \text { The United States. }\end{array}\right\}$ For 8,000 acres of land.}

The board having ascertained the above to be a valid Spanish title, made previous to the 24th of January, 1818, and this claim being part thereof, regularly conveyed to claimant, it is, therefore, recommended to Congress for confirmation.

29th June, 1824. 
No. 4. R.

William Travers,

The United States. $\}$ For 12,000 acres of land.

\section{MEMORIAI.}

To the Honorable the Commissioners appointed to ascertain claims and titles to lands in East Florida.

The petition of William Travers respectfully sheweth: That your memorialist claimis title to a tract of land, consisting of twelve thousand acres, situated at the Lagoon, called south of Lake George, in St. John's river, bounded as follows : first line south $65^{\circ}$ west 320 chains, begiuning at a palmetto tree marked, to a pine tree with the same mark; thence, north $65^{\circ}$ east 320 chains, to a stake on the bank of said Lagoon. Which title your memorialist derives from an absolute grant, made to Felipe Roberto Yonge by Governor Coppinger, in virtue of the royal order of 29 th March, 1815, who sold the same to your memorialist, a certified copy of the grant, which was made the 22d February, 1817, is herewith filed. And your memorialist further sheweth, that be has possession of said lands; that he resided in Augustine at the change of flags, and still does so; that he is a citizen of the United States, and resident of St. Augustine.

\section{WM. TRAVERS.}

Title of property, for 25,000 acres of land, in favor of Don Fe. lipe R. Yonge.

\section{Don Jose Coppinger, Lieut. Col. of the Royal Armies, \&.c. \&c.}

Whereas, by a royal orler of the 29th March, 1815, His Majesty has deigned to approve the gifts and favors proposed by my predecessor, Don Sebastian Kindelan, for the officers and soldiers, both regular and militia of this province, who assisted in its defence at the time of the rebellion; one of the said favors being the distribution of royal lands, and considering that Don F. Robert Yonge has made evident to me, the distinguished and extraordinary services, by which he has contributed personally and with his money, to the defence of this said province at different times, and principally during the insurrection, which took place during the year 1812, with the sacrifice of his property, and saving to the royal treasury, as the memorial, which he has presented to me, of the date of the 5th of December, of the last past year, more fully shews; in consideration of which, and in virtue of the authority which I exercise, I have judged fit, by my decree of the eleventh instant, to accede to his solicitations, as set forth, and that, in remuneration, there shall be granted to him 25,000 acres of land, with a title in absolute property, to the south of the place known as Spring Garden, in this form: 12,000 acres of 
them in the neighborhood of the Lake or Lagoon, called "Second," and known as Valde's; and the 13,000 remaining, at the Lake higher up, known as Long Lake, all on the West of the river St. John's, with the reserve of establishing the boundaries and dimensions, when he proceeds to the survey of both tracts of land, as is shewn by the said memorial and decree, which exist in the archives of the notary. Wherefore, and in consideration of the said commendable services, agreeably with the will of the sovereign, and with what the laws recommend for distinguished rewards to those who are deserving, attending to the quality of said services, and of the persons who have performed them, I have granted, and in the name of his majesty, whose justice I administer, I do grant unto the said Don Felipe R. Yonge, the said 25,000 acres of land, in the places pointed out, without prejudice to a third person, for himself, his heirs, and successors, in absolute property, and in expediting to him, as by these presents I do, the corresponding title of property, by which I separate from the royal domain, in the right and dominion it had to said lands, and I cede and transfer it to the said Don Felipe R. Yonge, and his heirs and successor's, that in consequence they may possess it as their own, use and enjoy it without any incumbrance whatsoever, with all its entrances, outlets, uses, customs, rights and services, which it has bad, has and in fact and law belong or appertain to it, and at their will, sell, cede, transfer, and alienate it as may best suit them. In all which I interpose my judicial authority, as I can, and of right ought, in virtue of the sovereign will, and what has been set forth. Given under my hand, and countersigned by the notary of Government and the Rnyal domain, in this -said city of St. Augustine, Florida, the 22d February, 1816.

By order of this Excellency.

JOSE COPPINGER.

\section{JUAN DE ENTRALGO, Notary of Government and Royul domain.}

I certify the foregoing to be a true and correct translation, from a document in the Spanish language, on file in the office of the public archives of St. Augustine.

F. J. FATIO, S. B. L. C.

\section{Translation.}

POWER.

Be it known,'that I, Don Plilip R. Yonge, an inhabitant and merchant of this province, resident in this city, declare that I give all $\mathrm{my}$ fuil, ample, and sufficient power, which is required and may be necessary in iaw, unto Don Juan de Entralgo, Notary of Government and the Royal domain, in this said city, specially, that he may in my name, and representing my proper person, rights, and actions, ad- 
minister, and do administer, all and every my property, both landed and moveable, and unmoveable, sell some and purchase for me others, rent or mortgage them, for the prices and terms which he shall adjust and agree to, delivering the deeds, receipts, and letters of payment, which may be necessary, which form now I approve and ratify as if I were present at their delivery. For which sale of lands, houses, or any my property whatsoever, which I may have in this said province, he shall govern himself, precisely by the instructions which I have given, and shall give him on the subject; since with them I confer on him sufficient power, without any other limitation, free, open, and general administration, incidencies and dependencies, power to prepare causes for judgment, to swear and substitute, revoke, substitutei, and name others with substitution in form. And for the fulfilment of what he shall perform in virtue of this power, I bind myself, with my property present and fature, power and submission to the tribunals of his Majesty, that may compel me to its performance, as by sentence consented to and passed on authority of an adjudged case, on which I renounce all laws, customs, rights, and privileges, in my favor, and the general in form which prohibits it. In testimony of which, this is dated in this city of St. Augustine, Florida, the 29th May, 1819; I, Don Jose Cuppinger, Colonel of the Royal Armies, political and military, Governor of this city and its provinces, for his Majesty, certify, for the want of another notary, that I know the grantor who acknowledged the same, and signed with me and the assistant witnesses I have chosen for this act, Don Tomas Aguilar and Don Antonio Alvarez; there being also witnesses to this power present, Don Domingo Reyes, Don Manuel Faestes, and Don Nicolas Garrido.

COPPINGER;

PHILIP R. YONGE, ANTONIO ALVAREZ, TOMAS DE AGUILAR,

I certify the foregoing to be a true and correct translation from a document in the Spanish language, on file in the office of the public archives of St. Augustine.

$$
\text { F. J. FATIO, S. B. L. C. }
$$

\section{CONYEYANCE.}

Be it known, that I, Don Juan de Entralgo, Notary of Government and the public domain in this city, as Attorney for Don Philip Robt. Yonge, citizen of this province now absent, which power he has conferred on me in this office, on the 29th of May, 1819, before Senor Don Jose Coppinger, Colonel of the National Armies, Military Governor and Political Chief of this said City and its Province, and before witnesses, assisting for want of another Notary in the Province, which power is not revoked, and will be sufficient for what shall be said; in virtue of which, $I$ also have written orciers 
and instructions of the same principle and of the same date, for the purpose; I declare, that I really sell to Don William Travers, inhabitant of this city, 12,000 acres of land of the property of my said principal, situated on the Lake named "Second," on the West side of said Lake, which were granted him by this government as a reward for services on the 11th of February, 1817; and on the $22 \mathrm{~d}$ of the same a competent title in absolute property and dominion, was issued to him, the dimensions of which are distinguished under the following form: The first line runs south $65^{\circ}$ west, measures 320 chains, beginning with a palmetto marked $\equiv$, and finishing with a pine of the same mark. The second line begins with said pine, running north $25^{\circ}$ west, measures 400 chains, and ends with a stake. The third line begins with said stake, north $75^{\circ}$ east, measures 320 chains, and terminates with another stake in the neighborhood of Second Lake, as appears from the plat formed by the Surveyor Don Andrew Burgevin, on the 2d of August, 1819, agreeable to superior order, which, with the other documents $I$ refer to, are added to the proceedings on the business, which are in the archives in my charge; and $I$ sell him the said 12,000 acres of land at the place, and under the dimensions and terms expressed, with all its entrances, outlets, uses, customs, rights, and services which they have and belong to them, free of all incumbrance, (as I the seller certify, from the result of the book of mortgages, which I have searched for the purpose) at the price of 12,000 dollars, which the purchaser has paid me in cash, which sum I acknowledge as delivered to my will : I renounce proof laws of delivery, exception to money not counted, fraud and every thing besides in the case, for which I deliver a formal receipt, in virtue of which I separate from him who empowered me, the right of property, possession, use, seignory and other actions, real and personal, which he had or held to the said 12,000 acres of land which I cede, renounce, and transfer to the purchaser; and whoever shall represent his right that they may possess, sell, and alienate them at their will, in virtue of this writing, which I deliver in his favor, as a mark of real delivery with which it is seen that he has acquired its possession without occâsion for any other proof, from which 1 relieve him; and I oblige myself to the erection and guarantee of this sale in due form, and as may be most favorable to the purchaser, with the property of my principal, present and future, power and submission to the tribunals of H. M. that they may compel him to its compliance, as by sentence consented to and passed on authority as a thing adjudged, on which I renounce all laws, customs, rights, and privileges, in his favor, and every thing in form which prohibits it, and being present, I, the said purchaser accept in my favor this writing, and by it receive as purchased, the said 12,000 acres of land, at the price and agreement which they were sold to me; and $\mathrm{I}$ acknowledge them as delivered to my disposal, with a renunciation of proof, laws of delivery, those of a thing not seen or received, fraud, and any thing else in the case, for which I deliver a formal receipt. In testimony of which, this is dated in the City of St. Augustine, 
Florida, the $22 \mathrm{~d}$ of December, 1820 , I, the Notary, as the only one in this City, and as the seller sign this writing myself and before me, with the purchaser and the witnesses, who are Don Pedro Miranda, Don Jose Mariano Hernandez, and Don Fernando de la Maza Arredondo, jun. witnesses present.

For and before me, JUAN DE ENTRALGO, WM. TRAVERS.

I certify the foregoing to be a true and correct translation from a document in the Spanish language, on file in the office of the public archives of St. Augustine.

$$
\text { F. J. FATIO, S. B. L. } C \text {. }
$$

\section{Decree.}

The Board having ascertained that the foregoing is a valid Spanish grant, made previous to the 24 th of January, 1818 , do therefore recommend it to Congress for confirmation.

July 12 th, 1824.

No. 5 .

$\left.\begin{array}{c}\text { Juan B. Entralgo, } \\ \text { vs. } \\ \text { The United States. }\end{array}\right\}$ For 4,000 acres of land.

MEMORIAL.

To the Hon. the Commissioners appointed to ascertain claims and titles to lands in East Florida.

The petition of Juan B. Entralgo respectfully sheweth, that your Memorialist claims title to a tract of land consisting of 4,000 acres, situated at a place called Big Spring, on the river St. John's, and about 25 miles South of Lake George, on the West bank, bounded as follows : on the East by St. John's river; on the North by lands of Pedro Miranda; on the South by vacant lands; on the West by lands also belonging to Pedro Miranda, (see description in the grant filed herewith) which title your memorialist derives from a grant made to Pedro Miranda by Governor Coppinger, in virtue of the Royal order of 29th of March, 1815, who sold the same to your Memorialist, (see Document A.) the said 4,000 acres being part of a grant made as above stated to Pedro Miranda for ten thousand acres, dated April 11 th, 1821 ; and this title is founded upon a memorial and concession, made September 18th, 1817, by Governor Coppinger; and your Memorialist further sheweth, that he has possession of said lands, and was at the exchange of flags, living in St. Augustine, at present resides in Cuba.

JUAN B. ENTRALGO, BY GE0. MURRAY. 


\section{Transhatron.}

Senor Governador:

Don Pedro Miranda, first Pilot of the bar and Captain of the Port, with due respect states to your excellency, that the Government is well aware of the services which the memorialist has performed from the insurrection in this province, in the year 1812. contributing with his person and property to its defence, besides there having been, and now being, in his charge, several extraordinary commissions, for which he has never had any recompense ; it is also certain and well known, that in the insurrection of the year 1794, he was likewise engaged in an extraordinary manner and employed in other commissions for the Royal service, having contributed on all occasions with his greatest exertions to the economy of the Royal Treasury. For these considerations, and that of having served his majesty from his youth, and being of the first families that came on the occupation of this Province, which circumstance of being a settler, makes him entitled to the favor of a grant of land as has been given to others, since those which your excellency has been pleased to grant him do not equal your liberality to those: wherefore, he prays your excellency to be pleased to grant him in absolute property and dominion, ten thousand acres of land on a creek which runs from the West and joins the river St. John's, called in English Big Spring, about 25 miles to the South of Lake St. George; the said land to be divided in two parts by said creek, and to have one of its fronts on the river St. John's, leaving free the concession of two thousand acres which were made to him on the first of July last, reserving the titles of property until he can complete the survey and plat, it being out of his power at present to pay the expenses, a favor he hopes from the justice of your excellency. St. Augustine, Florida, 15th of September, 1817.

\section{St. Augustine, 15 th Sept. 1817.}

\section{PEDRO MIRANDA.}

In attention to what Don Pedro Miranda represents in the foregoing memorial, and as the services he mentions are certain, agreeing at the same time with what the laws and royal orders direct for the encouragement of population, I grant him in the name of his majesty, and of his royal justice, which I administer, the ten thousand acres of land in the places which he points out, that he may enjoy them in absolute property and dominion; for which end, and that he may prove this grant, let a certified copy of the proceeding be furnished him, which shall be lodged in the Notary's archives, from whence titles in form shall be given him speedily, or whenever required by the interested.

\section{COPPINGER.}

I certify the foregoing to be a true and correct translation from a document in the Spanish language, on file in the oflice of the public srchives of St. Augustine.

$$
\text { F. J. FATIO, S. B. L. C. }
$$


[TRANSLATION.]

Don Andres Burgevin, inhabitant of this City, and private Surveyor.

I certify, that in consequence of power conferred upon me, by a decree of the 12th of December, 1820, made at the instance of Don Pedro Miranda, I have surveyed for this individual, various pieces of land, to the number of ten thousand acres, which were granted him as a reward for services, on a creek which comes from the West and joins the river St. John's, called, in English, Big Spring about twenty-five miles to the South of Lake St. George, the land divided in two parts by said creek. leaving one of its fronts on said river St. John's, one of the said pieces being the following: Four thousand acres, which are bounded on the East by said river St. John's, on the North by lands of the interested, on the South by lands also vacant, and on the West by another piece of three tliousand four hundred acres of the said interested. And, for its confirmation, I sign these presents at St. Augustine, Florida, 5th of April, 1821.

\section{ANDRES BURGEVIN.}

\section{[Plat is annexed.]}

Royal title to P. Miranda, for 4,000 acres, part of a concession of 10,000 acres to him, is not translated; the following transfer is at foot of it:

\section{[TRANSLATION.]}

I cede and pronounce in favor of Don Juan Blas de Entralgo, all the right, title, and dominion, which I have to the 4,000 acres of land which this document of property contains, for having sold them at the rate of $\$ 1,500$, for which I deliver a formal receipt.

\section{PEDRO MIRANDA.}

Witnesses present,

F. J. FATIO, RUPERTO SAVEDRA.

St. Augustine, 5th of Dec. 1821.

I certify the foregoing to be a true and correct translation from a document in the Spanish language.

$$
\text { F. J. FATIO, S. B. L. C. }
$$

\section{Decree.}

\section{$\left.\begin{array}{c}\text { J. B. Entralgo } \\ \text { v8. } \\ \text { The United States. }\end{array}\right\}$ For 4,000 acres of land.}

The Board having ascertained the above to be a valid Spanish concession, made previous to the 24th of Jaouary, 1818, and this claim being part thereof, and conveyed to claimant, it is therefore recommended to Congress for confirmation.

29 th June, 1824. 


\section{No. 6 .}

\section{Antonio Huertas, \\ The United States. $\}$ For 10,000 acres of land.}

\section{MEMORIAL.}

To the Honorable the Commissioners appointed to ascertain claims and titles to lands in East Florida.

The memorial of Antonio Huertas, late of St. Augustine, in East Florida aforesaid, now residing at Havana, in the Island of Cuba, respectfully sheweth; that your memorialist claims title to ten thousand acres of land situated on Six Miles Creek, bounded westward by the said creek, eastward by the large mount, southward by the road of Picolata, running northward to its termination, being the same land, formerly granted to Panton, Leslie and Co. and afterwards relinquished by them. The grant to your memorialist of said land was made on the 27th March, 1813, in virtue of the royal orier of the 29th October, 1790, and an absolute title granted to your memorialist by Governor Coppiuger, on the 20th July, 1816. The original grant, absolute title, and survey, are in the office of public records in the city of St. Augustine, kept by William Reynolds, Esq. And your memorialist further sheweth that he was a resident inhabit of East Florida at the time of its cession tu the United States, and in possession of the said land; that he had for about $\$ 6$ years previous to said cession. resided in the city of St. Augustine, whence he removed to the Havana in the year 1822; all of which is respectfully submitted.

ANTONIO HUERTAS,

By his Attorney,

JOHN RODMAN.

St. Augustine, 25th Novr. 1823.

TRANSLATION.

Title of property in favor of Don Antonio Huertas, for ten thousand. acres of land in the place known as Six. Miles Creek.

Don Jose 1'oppinger, Lieutenant Colonel of the Royal Armies, Civil and Military Governor pro tem, and Chief of the Royal Finance of this city of St. Augustine, of Florida, and its province : Whereas by Royal order communicated to this Government the 29th October, 1790, by the Captain General of the Island of Cuba and two Floridas, it is provicied among other things that, to those foreigners who of their free will present th-mselves to swear allegiance to our sovereign, lands should be measured them gratis in proportion to the laborers each family may have. That Don Antonio Huertas of this place having presented himself, he solicited of the Government, and there were granted him on the 27th of March 1813, ten thousand acres of land, for the raising of stock, in consideration of his 
faithful and constant services to the country, and for the injuries which he suffered by the insurrection of this province, which lands are known by the name of Six Miles Creek. ant are distinguished un. der the following boundaries: commencing on the west by said creek; on the east by the Big Wuod; on the south by the Picolata road, and following north to where it corresponds. And the said lands being the same which the house of Panton, Leslie \& Co. to whom they were granted, abandoned, and as the said Don Antonio Huertas has solicited, there should be expedited to him the title of absolute property, as he has established a cowpen on said lands, where he iears stock, as he has madie appear by evidence, in virtue of wlrich, and in attention to his said good services, I have granted him by my decree of the 17 th of the present month, placed on the proceedings moverl by the aforesaid Din Antonio Huertas, where all appears more in detail. and is filed in the office of the present nutary. Wherefore, and in consideration of all I have thought proper to grant as in the name of his Majesty, I do grant to the said Don Antonio Huertas, the said ten thousand acres of land for himself, his heirs and successors, in absolute property, and in granting to him, as by these presents I do, the corresponding title, by which I separate the Royal Domain from the right and dominion which it had in said land. and $I$ cede and transfer it to the aforesaid Don Antonio Huertas, his heirs and successors, that in consequence thereof, they may possess it as tieir own, use and enjoy without any incumbrance whatever, with all its entrances, outlets, uses, customs, rights, and services, which it has had, has, or by fact and law may belong or appertain to it, and being their will they may sell, cede, transfer, and alienate it as may best suit them. To all of which I interpose my authority as far as I can, and by right ought, in virtue of what has been set forth, and of the sovereign will. Given under my hand and countersigned by the undersigned notary pro tem. of Government and Royal Finance in this city of St. Augustine, Florida, the 20th of July 1816.

\section{JOSE COPPINGER,}

By order of his Excellency,

IUAN DE ENTRALGO, Notary of Govt. and Royal Finance.

I certify the foregoing to be a true and correct translation from a document in the Spanish language on file in the oftice of the Public Archives of St. Augustine.

F. J. FATIO, S. B. L. C.

\section{DECREE.}

\section{Antonio Huertas, The United States. For 10,000 acres of Land.}

The Board having ascertained this to be a valid Spanish Title, made previons to the 24 th January, 1818 , it is therefore recommended to Congress for confirmation.

September 1st, 1824. 
No. 7 .

\author{
$\left.\begin{array}{c}\text { Juan B. Entralgo, } \\ \text { vs. } \\ \text { The United States. }\end{array}\right\}$ For 20,000 aeres of Land.
}

\title{
MEMORIAL.
}

To the Honorable the $\mathbf{C o m m i s s i o n e r s ~ a p p o i n t e d ~ t o ~ a s c e r t a i n ~ c l a i m s ~}$ and titles to Land in East Florida, the Petition of Jnan B. Entralgo, respectfully sheweth, that your memorialist claims title to a tract of Land consisting of twenty thousand acres, situated at Chachala, in the district of Alachua, and 45 miles west of St. John's river, embracing the residence of the late Indian Chief Payne, and bounded as follows: beginning at a Pine tree, and running East 625 chains to a Pine, thence North 320 chains to a stake, thence West 625 chains to a stake, thence South 320 chains to the beginning. See survey and plat made by Burgevin and filed herewith, marked C, which title your memorialist derives from a grant made to George I. F. Clarke, by Governor Coppinger, in virtue of the Royal order of 29th of March, 1815, who sold to your memorialist the said 20,000 acres, being part of a grant of twenty-two thousand acres made the 17 th of December, 1817 , which is filed herewith, marked A, as is also the deed from Clarke to your memorialist marked B; and your memorialist further slieweth, that he has legal pessession of said lands, and that he is a Spanish subject residing in Cuba, but, at the cession in 1821, was an inhabitant of St. Augustine. He prays his title to the said 20,000 acres may be confirmed.

\section{JUAN B. ENTRALGO. By GEORGE S. MURRAY.}

A.

\section{CONVEYANCE.}

Title of property of 22,000 acres of land, in favor of Don Jorge Clarke in the hammocks of Cuscouillo and Chachala.

Don Jose Coppinger. Colonel of the Royal Armies, Governor political and military pro tem: and Chief of the Royal Domain of this city of St. Augustine, Florida and its Province, for his Majesty.

Whereas in a Royal order of the 29th of March, 1815, His Majesty has deigned to approve of the favors and rewards proposed by my predecessor Brigadier Don Sebastian Kindelan for the officers and soldiers, both veterans and militia of this province, gwho assisted in its defence at the time of the rebellion, one of the said favors being the distribution of public lands, and as Don Jorge Clarke, Lieutenant of loeal militia, has represented to me the distinguished services which he has rendered both personally and in a pecuniary manner, in the defence of the said province at several periods of invasion, with the sacri-

fice and abandonment of his interest and property like a faithful sub. 
Ject as he has been, worthy of every recompense for his zeal, love, and lidelity to the Sovereign, which extraordinary services, which are well known to me, are set forth by his memorial of the 13 th inst. in virtue of which $\mathbf{I}$ have thought proper, by my decree of this day, to accede to his request relative to the grant of twenty-two thousand acres of land, with a Title in absolute property, in the hammocks known by the name of Cuscouilio and Chachala, situated on the West of the part of the river St. John, where there was a store of the house of Panton, Leslie and Company, and about forty-five miles distant from it, all of which appears more at large from the said memorial and decree which exist in the archives of the present notary. Wherefore and in attention to the said recommendable services, agreeably to the sovereign will, and what the laws enjoin, for the rewarding with distinction those who may be entitled, attending to the services, and that of the persons who may perform them, I have granted as in the name of his Majesty and of his Royal Justice which I administer, I do grant, unto the aforesaid Don Jorge Clarke, the said 22,000 acres of land in the place pointed out, without injury to a third person, for himself, his heirs, and successors, in absolute property, and despatch to him, as by these presents I do, the corresponding title by which I separate the Royal Domain from the right and dominion it had to said land, and I cede and transfer it to the aforesaid Don Jorge Clarke, his heirs and successors, that in consequence they may possess it as their own, use and enjoy it without any incumbrance whatsoever, with all its entrances, outlets, uses, customs, rights and services, which it has had, has, and of custom and by law, belong and may appertain to it, and at their will, sell, cede, transfer and alienate it as may best suit them. To all which I give the sanction of my authority as I can and of right ought to do in virtue of the sovereign will.

Given under my hand, and countersigned by the undersigned notary of Government and the Royal Domain, in this city of St. Augustine, Florida, the 17 th of December, 1817.

\section{JOSE COPPINGER. By command of His Excellency. JUAN DE ENTRALGO, Notary of Government and the Royal Domain.}

I certify the foregoing to be a true and correct translation of a do. cument in the Spanish language, on file, in the office of the public archives.

F. J. FATIO, S. B. L. C.

\section{Conveyance.}

Be it known, that I, Don George Clarke, an inhabitant of this Province, residing in the Town of Fernandina, but at present an inhabitant of this City, covenant, that I really sell unto Don Juan de Entralgo, Notary of Government, and the Royal Domain in it, 
twenty thousand acres of land, which I hold as my property, in the Territory of Alachua, and a place named Chachala Hammock, on the west side of the river St. Johns, where there was a store of the house of Panton, Leslie \& Company, and distant from it about fortyfive miles. The first line east, measures 625 chains; the second line north, measures 320 chains; the third line west, measures 625 chains; and the fourth line south, measures 320 chains; which 20,000 acres of land belong to the 22.000 granted me by this Government, as a reward for services on the 17th of December, 1817, and for which the corresponding title of property was made me on the same day, having proceeded to the survey of the private surveyor, Don-Andrew Burgevin, who made the necessary plat, on the 2d of August, 1819, which is added to the original proceedings of said concession, and is in the archives of the said Notary. And I sell the said 20,000 acres of land, in the place and under the dimensions marked out, and with all their entrances, outlets, uses, customs, rights, and services, which it has, or of right belong to it, free of all incumbrance, (as appears from the book of mortgages which is in charge of the said notary, ) at the price of 20000 dollars, which the purchaser has paid to my entire satisfaction, which I acknowledge as delivered to my will; I renounce proof, laws of delivery, exception to money not counted, fraud, and every other thing in the case, for whieh I deliver a formal reccipt. in virtue of which I separate myself from the right of property, possession, use, seigniory, and other rights, real and personal, which belong or appertain to the 20.000 acres of land abovementioned, as I cede, renounce and transfer it to the purchaser, and whoever shall represent his right. that he may possess, sell, and alienate it at his will in virtue of this deed, which I grant in his favor. as a mark of real delivery, by which it is seen that he has acquired possession of it without occation for other proof, from which I release him, as I remain released from the eviction and gnarantee of this sale, to which I do not bind myself. And I, the said Don Juan de Entralgo, being present, do ac cept in my favor this deed, and by it receive as purchased, the said 20,000 acres of land at the price and agreement at which they have been sold to me, and I acknowledge them as delivered to my will; I renounce proof, laws of delivery, those of a thing not seen or received, fraud, and every thing else in the case, for which I deliver a formal receipt in form. In testimony of which this is dated, in the City of St. Augustine. Florida, the 7 th of February, 1820. 1, Don Jose Coppinger, Colonel of the Royal Armies, Political and Military Governor of this City and Province, certify that I know the parties, who also have delivered and signed it in my presence, and that of the assistant witnesses whom I have chosen for the purpose, Don Tomas de Aguilar, and Don Antonio Alvarez, for want of another Notary in all the Province, there being witnesses to this deed, Don Domingo Reges, Don Pedro Miranda, and Don Fernando Arredondo, junior, inbabitants present. Jose Coppinger, George J. F. Clarke, Juan de Entralgo, Tomas de Aguilar, Antonio Alvarez. 
This is conformable to the original which exists in the archives of the said Notary of Government, to which I refer, and at request of the party, sign this present copy, with the assistant witnesses, on two leaves of common paper, the stamped not being in use..-St. Shugustine, Florida, the 7 th of February, 1820.

\section{JOSE COPPINGER, ANTUNIO ALVAREZ.}

\section{Tomas de Aguilar.}

I certify the foregoing to be a true and correct translation, from a document in the Spanish language, on file in the office of the public archives of St. Augustine.

F. J. FATIO, S. B. L. C.

\section{SURVEY.}

TRANSLATION.

- Don Andres Burgevin, an inhabitant of this City, and surveyor, appointed by Don George Clarke, and authorized by the Government, under date of the 20th of April, 1819, for the survey of his land.

I certify that I have measured and laid off, for the said Don George Clarke, 20,000 acres of land, in the Territory of Alachua, and a place named Chachala, on the west of the river St. Johns, and distant from it about forty-five miles, in part of a greater quantity which were granted him by a title of property on the 17 th of December, 1817 , and appears in its circumstances conformable to the following plat, and its original, delivered into the archives of the Notary of this Government, in proof of which $\mathbf{I}$ give these presents, which $\mathbf{I}$ sign at St. Augustine, Florida, the 2d of August, 1819.

\section{ANDRES BURGEVIN.}

\section{[Here follows the plat.]}

I certify the foregoing to be a true and correct translation, from a document in the Spanish language, on file in the office of the public archives of St. Augustine.

$$
\text { F. J. FATIO, S. B. L. C. }
$$

\section{DECREE.}

$\left.\begin{array}{c}\text { Juan B. Entralgo } \\ \text { vs. } \\ \text { The United States. }\end{array}\right\}$ For 20,000 acres of land.

The Board having ascertained the above to be a valid Spanish title, made to G. J. F. Clarke, previous to the 26th' of January, 1818, and this claim for 20,000 acres thereof, being regularly conveyed to claimant, it is, therefore, recommended to Congress for confirmation.

29 th June, 1824. 
No. 8.

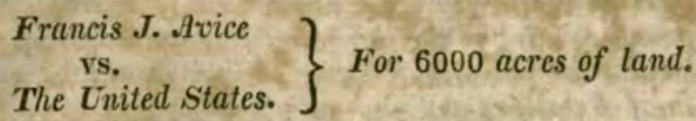

MEMORIAL.

To the honorable the Commissioners appointed to ascertain claims and titles to lands in East Florida:

The memorial of Francis J. Avice, respectfully sheweth, that your memorialist claims title to a tract of land, consisting of six thousand acres, situated on the river St. Johns; bounded north by lands granted to Juan Huertas; and south by lands of John Moore; east by vacant lands; and west by the river St. Johns; which were granted to Juan Huertas by the Spanish Government, the 25th Augusit, 1814, in virtue of the royal order of the 29th of October, 1790 ; and for which lands the said Huertas received a title from Governor Coppinger, by virtue of authority in the said Coppinger, for that purpose reposed by the Spanish Government, upon the 24th December, 1817. Which title and a plat of the survey of said tract of land, are herewith filed and marked C, and D. And, your memorialist further sheweth, that he became proprietor of said tract of land, by virtue of a bill of sale from the said Juan Huertas to your memorialist, dated upon the 12th of September, 1821, which is also herewith exhibited and marked $L$. Your memorialist further sheweth, that he is actually legally secured and possessed of said land; that he is a citizen of the United States, and resident of the city of St. Augustine.

All which is respeetfully submitted, \&c.

FRANCIS J. AVICE.

\section{TRANSIATION.}

Title of property in favor of Don Juan Huertas, of 15,000 acres of land, in the places set forth:

Don Jose Coppinger, Colonel of the royal armies, civil and military Governor, pro. tem. and chief of the royal province of this city and province, by his Majesty.

Whereas, by royal order, communicated to this Government, the 29th October, 1790, by the Captain-general of the Island of Cuba and two Floridas; among other things, it is provided that to strangers, who, of their own free will, shall present themselves to swear allegiance to our Sovereign, lands should be laid out for them, free of expense, in proportion to the number of laborers each family may have: that Don Juan Huertas, having presented bimself, he solicits of this Government the concession of 15,000 acres of land, as a compensation for his aid and known services; and for the purpose of establishing a cowpen, and the remaining of Blade South, which was granted him the 29th of March, 1814, in consideration of the truth of his petition, according 
to the following boundaries: 5000 acres at a place called Tocoy, five miles above Picolata; bounded on the north by lands of Don Manuel Solano; on the southwest by vacant lands; and on the west by the river St. Johns: and the remaining 10,000 acres on the banks of the river, about 12 miles above a place called the Fury, below D. Royant; bounded on the south by the lands of John Mare; and from thence east to the head of Deep creek, taking in east and west banks of said creek; and bounded on the north by the south west line of Tocoy; and on the west by the river St. Johns; as results from a certificate by the Setretary of this said Government, with the said date of the 26th of August, 1814, which is found attached to the procuedings instituted by the above mentioned Don Juan Huertas, praying that the corresponding title of the said lands given him. Therefore, and in consideration that the abovementioned Don Juan Huertas has fully proved his having established said cowpen, and that he employed himself with the object of said concession, as is seen by the said proceedings, filed in the archives of the present Notary, and according to my decree of the $22 d$ of the present month, I have granted, and by these presents do grant, in the name of his Majesty, to the said Don Juan Huertas, his heirs and ancestors, the said 15,000 acres of land, in absolute property; and I hereby, and by these presents deliver him the corresponding title, by which I separate it from the royal domain, from the right and dominion it held in said lands; and I will transfer it to the aforesaid Don Juan Huertas, his heirs and successors, that in consequence thereof, they may possess it their own, make use of it, and enjoy it free from any claim whatever, with all its entrances, outlets, uses customs, rights, appurtenances; and all are in general, which hath, doth, or may belong or pertain thereto; and it being their wish, they may sell, cede, transfer, barter, and alienate it at their will or pleasure. To all of which I interpose my authority, as far as possibie and according to law, in virtue of the Sovereign will.

Given under my hand, and countersigned by the undersigned Notary of Government and Royal Finance, in the city of St. Augustine, Florida, the 24th of December, 1817.

JOSE COPPINGER.

By order of his Excellency \&c. \&c.

JUAN DEE ENTRALGO.

Conformable to the original on file in the archives, under my charge, to which I refer, and at the request of the party, do seal and sign the present copy, in St. Augustine, the 18th of September, 1821.

\section{JUAN DE ENTRALGO.}

Don Andres Burgevin, in this city, and private surveyor: I certify that $I$ have measured and laid off for Don Juan Huertas, a tract of land containing 6,000 acres, being part of one of 10,000 acres, situated at Buena Vista, which I measured by order of this Government, 
for the said Don Juan Huertas, and being conformable in all its parts, to the following plat; I seen it in St. Augustine.

Florida, the 30th May, 1820.

ANDRES BURGEVIN.

\section{A copy-A. Burgevin.}

(Here follows the plat.)

I certify the foregoing to be a true and correct translation from two documents in the Spanish language.

F. J. FATIO, S. B. L. C.

TRANSIATION.

Know ye, that I, Don Juan Huertas, resident of this city, do really sell to Don Francisco Julian A vice 6000 acres of land, situated between the old fort of Buena Vista and a place near where the military post is stationed, or properly known by the name of Moore; which 6000 acres of land are part of 18000 , conceded to me by this Government, giving me for the same, a title of absolute property on the 24th of December, 1817, which are known and distinguished under the following dimensions and boundaries: bounded on the North by the lands of Don Pedro Concessance, near the old fort of Buena Vista; on the East by vacant lands; on the South by those of Moore; and on the West, by the river St. John's. And I sell him the boundaries and dimensions already explained, and the place pointed out, with all its entrances, outlets, uses, customs, rights, and appurtenances, which it has, or may belong to it, free from any claim whatever, in the sum of 3075 dollars, which the purchaser has paid me in cash. In virtue of all of which, I separate myself from the right of property and possession I had to said land, which I cede, renounce, and transfer, in favor of the purchaser, and in whomsoever may represent his right, that he may, as his own, dispose of it at his will, binding myself to the eviction and goodness of this sale, in favor of the purchaser, with my present and future property, with power to the tribunals, that they may compel me to the compliance thereof. And I, the said Don Francisco Avice, being present, do accept in my favor, this deed, and by it received as purchased the said 6000 acres of land, in the price and manner they are sold to me. Both parties signing these presents in the presence of the witnesses, who also signed in St. Augustine, Florida, the 12th of September, 1821.

Witnesses,

JUAN HUERTAS, F. J. AVICE.

Francis J. Fatio,

Charhes Ukguhes. 
I certify the foregoing to be a true and correct translation from a document in the Spanish language.

\section{DECRER.}

The Board having ascertained the above to be a valid Spanish grant, made previous to the 24th of January, 1818, do therefore recommend it to Congress for confirmation. April 14, 1824.

No. 9.

Joseph M. Arredondo,

The United States. $\}$ For 20,000 acres of land.

\section{MEMORIAL.}

To the honorable the Commissioners appointed to ascertain claims and titles to land in East Florida.

The petition of Joseph M. Arredondo, respectfully sheweth: That your memorialist claims title to a tract of land consisting of twenty thousand acres, situated at a place called the Big Hammock, about twenty miles from the river Suwannee, which title your memorialist derives from a royal title, made to him by Governor Coppinger, in virtue of the royal order of the 29th March, 1815, a certified copy of the said title is herewith filed, and is dated 20th March, 1817. And your memorialist further sheweth, that he is legally in possession of said lands, and was so, before the cession in 1821; that he is a Spanish subject, native of East Florida, and at present a resident of the Island of Cuba.

JOSE M. ARREDONDO.

\section{TRANSLATION.}

Title of property in favor of Don Jose de la Maza Arredondo, for 20,000 acres of land.

Don Jose Coppinger, Lieutenant Colonel of the Royal Armies, Political and Military Governor pro tem., and Chief of the Royal Domain of the city of St. Augustine, Florida, and its Province: Whereas, by royal order of the 29th of March, 1815, his Majesty has been pleased to approve the favors and rewards proposed by my predecessor, the Brigadier General Don Sebastian Kindelan, for the officers and soldiers, both of the reguiars and militia of this province, who contributed to the defence thereof, during the rebellion, one of the said favors being the concession of vacant lands; and whereas, Don Jose de 
la Maza Arredondo, Captain of the local militia of the Spanish company, in the town of Fernandina, has made known to me the distinguished and extraordinary services rendered by him in a personal and pecuniary manner, in the defence of this said province, during the insurrection therein, with econohy to the royal revenue, as a faithful subject, as is fully stated, in his memorial, dated the 18 th of the present month, according to which, by my decree of this day, $I$ have thought proper to accede to his prayer, relative to the granting him twenty thousand acres of land, with a title of absolute property in the lands known by the name of Alachua, about eighty miles distant from this city, at a place called Big Hammock, about twenty miles from the river Suwannee, and sixty miles West of St. John's river, not preventing, as soon as there is an opportunity, and the tranquillity of the province is entirely re-established, that a survey of the lands be made, that the limits and boundaries may be made known by the corresponding plat, as will be fully seen by the said proceedings filed in the office of archives of the present Notary: Wherefore, and in consideration of said commendable services, agreeably to the will of the Sovereign, and what is set forth in the laws to recompence, with distinction, those who may be worthy, according to the nature of said services, and the individuals who have rendered them, I have thought proper to grant, and by these presents do grant, in the name of his Majesty, and his royal justice, which I administer, to the said Don Jose de la Maza Arredondo, the said twenty thousand acres of land, in the place pointed out, without injury to a third person, for himself, his heirs, and successors, in absolute property, and in granting, as I do by these presents, the corresponding title, by which I separate the Royal Domain from the right and dominion it had to said land, and I cede and transfer the same to the above mentioned Don Jose de la Maza Arredondo, his heirs and successors, that they may, in consequence thereof, possess the same as their own, make use of and enjoy it, free from any incumbrance whatever, with all its entrances, outlets, uses, customs, rights, and services, which it has had, has, and of custom, and by law, belong, or may appertain thereto, and being their will, they may sell, cede, transfer, and alienate it as may best suit them. To all which I give the sanction of my authority, as I can, and of right ought to do, in virtue of the sovereign will.

Given under my hand, and countersigned by the undersigned $N_{0}$ tary of Government, and Royal Domain, in this said city of St. Augustine, Florida, the 20th of March. 1817.

By order of his Excellency. JOSE COPPINGER.

JUAN DE ENTRALGO, Notary of Government and the Royal Domain.

I certify the foregoing to be a true and correct translation from a document in the Spanish Ianguage, filed in the office of the public archives.

F. J._FATIO, S. B. L, $C$. 


\section{$\left.\begin{array}{l}\text { Joseph .M. Arredondo, } \\ \text { vs. } \\ \text { The United States. }\end{array}\right\}$ For 20,000 acres of land.}

The Board having ascertained the above to be a valid Spanish title, made previous to the 24th January, 1818, do therefore recommend it to Congress for confirmation.

Aprib 16 th, 1824.

No. 10.

Charles W. Bulov's Executors vs.

The United States.

\} For 4,000 acres of land in two

\section{MIEMORLAL.}

To the Honorable the Commissioners appointed to ascertain claims and titles to lands in East Florida.

The Memorial of John Geddes, Duke Goodman, and William Lance, Executors of the last will and testament of Charles W. Bulow, deceased, on behalf of the heirs of the said Bulow, respectfully sheweth : That the heirs of the said-Bulow claim title to four thousand acres of land, comprised in two separate tracts, as follows: The first tract is situated between the Rivers Tomoka and Matanzas, in the place called Graham's Swamp, containing 3,486 acres, bounded on the west by the public road from Musquito to St. Augustine, on the north and north-east by a marsh and the hall over creek, and on the south by the lands of Mrs. Ormond. The second tract contains 514 acres, is situated on the west side of the river Halifax, bounded on the south by John Russell's land, on the north by Farquhar Bethune's laid, and on all other sides by vacant lands, which two tracts above mentioned, making 4000 acres, were granted to John Russell by the Spanish Government under Governor Estrada, on the 28th July, 1812, in exchange for a vessel called the schooner Barbarita, which will fully appear by a reference to a volume of original documents on the subject, stitched together and remaining in the office of public archives, kept by W. Reynolds, Esq. in this city, to which are annexed the order of survey, certificates of survey of plats. And your memorialists further shew that immediately on receiving the said grant the said John Russell took possession of the said land, but a few years afterwarls died, and the title to the same was confirmed by the Spanish Government to his heirs, as appears by the above documents; that the said Charles W. Bulow purchased from the heirs of Russell, for a valuable consideration, on the 1st August, 1821, the two tracts 
of land aforesaid, the deed of conveyance for which is recorded in the Public Office of Records in the city of St. Augustine, kept by Mr. Tingle. That in virtue of the said purchase the said Charles W. Bulow immediately took possession of the said tracts of land, and planted and improved a part of one of the tracts and erected buildings. That your memorialists still keep a great number of slaves on the said land employed in the cultivation of the cane. That the said $\mathbf{C}$. W. Bulow died in the city of St. Augustine a few months ago, a citizen of the United States. All which is respectfully submitted by

\section{JOHN RODMAN,} Attorney for claimants.

St. Augustine, 29th November, 1823.

$\left.\begin{array}{c}\text { Charles W. Bulow's Executors, } \\ \text { vs. } \\ \text { The United States. }\end{array}\right\} F_{0}$ r 675 acres of land.

MEMORIAI.

To the Honorable the Commissioners appointed to ascertain the claims and titles to lands in East Florida.

The memorial of John Geddes, Duke Goodman, and William Lance, Executors of the last will and testament of Charles W. Bulow deceased, on behalf of the heirs of the said Bulow, claim title to 675 acres of land, situated on the west side of the Halifax river, bounded on the north by lands of John Russell, on the south by lands of Fulano Dean, on the east by lands of John Russell, and on the west by vacant lands, which said tract of 675 acres was granted to the said John Russell by the Spanish Government under Grovernor Estrada, on the 28th July, 1812, on what is called head rights, in virtue of the Royal order of 29 th October, 1790, the original grant for which with the survey and plat is annexed to and forms a part of a volume of original documents relating to two tracts comprising 4000 acres of land, which were granted to John Russell at the same time, in exchange for a vessel called the Barbarita, which said volume of original documents are stitched together and remaining in the office of public archives, kept by W. Reynolds, Esq. in this city. And your memorialists further shew, that immediately on receiving the said grant the said John Russell took possession of the said land, but a few years afterwards died; and the title to the same was confirmed by the Spanish Government to his heirs, as appears by the above mentioned document; that the said Charles W. Bulow purchased from the heirs of Russell for a valuable consideration on the 1st August, 1821, the said tract of 675 acres, together with the two tracts making 4000 acres aforesaid, the deed of conveyance for which is recorded in the public office of Records in the city of St. Augustine kept by Mr. Tingle. That in virtue of the said purchase, the said Charles W. Bulow immediately took possession of the said tracts of land, and planted and 
improved a part of one of the tracts of land and erected buildings. That your memorialists still keep a great number of slaves on the said land employed in the cultivation of the cane. That the said C. W. Bulow died in the city of St. Augustine a few months ago, a citizen of the United States. All which is respectfully submitted by

St. Augustine, 29th Noro. 1823.

JUHN RODMAN, Attorney for claimants.

TRANSLATION.

Petition to his Excellency the Governor.

I, Mr. John Russell, a new settler in this Province, do appear before your Excellency, and with due respect say, that when I took the oath of fidelity and allegiance to his Catholic Majesty, his Excellency Don Juan Jose de Estrada, Governor pro tem. of this Province, insinuated to me, that the Government was in want of a vessel, the size of which should be calculated to go in and out over the bar of this harbor, and that as the funds of the Royal Treasury were exhausted, and such vessel could not be paid for in specie, they would be glad to buy it, and pay for it with a grant of land, proportioned to its value ; in consequence of that insinuation, $I$ ordered the building of the schooner, in which $I$ have just arrived to this port, with my family, and some of my slaves, called the Perseverance, of 58 tons burthen, drawing only six feet when loaded.

The capacity of the vessel, is equal to 300 flour barrels and more; her timber and materials are of the best quality, which can be ascertained by a survey of experienced men; on account of all which, besides being a fast sailing vessel, she is well calculated for this port, and $I$ offer the same to the Government, contenting myself to receive in payment for it, the title of absolute domain and property, to 4000 acres of land, situated in such part of this Province, as I may fix my choice; also the absolute title to such Iands, which $I$ have petitioned for, and which I am entitled to in virtue of my head rights, according to the number of persons composing my family, and that of my slaves. Therefore, I beg your Excellency to consider my preceding proposal as being actually made, and to accept it, should your Exceliency deem it just and reasonable.

St. Augustine of Florida, on the 8th of July, 1812.

JOHN RUSSELL.

DECREE.

Let the Governor pro tem. my predecessor, Don Juan Jose de Estrada, give such information as may be in his power.

KINDELAN. 


\section{INFORMATION.}

When I admitted as a vassal of his Catholic Majesty, our Lord Don Ferdinand the Seventh, the petitioner, which took place in the preceding year, as appears by the oath he took, which is registered in the Ofice of the Secretary of Government, he represented to me, that in Providence, of which place he was an inhabitant, he had left on the stocks, a schooner, in which he intended to bring to this place his family and property, and he believed that vessel was very well calculated for the service of this port, and he would offer it for sale to the administrator of the royal domain, in case it would suit. Having received this information, and knowing the general scarcity of specie in the Royal Treasury, I gave him to understand, through the organ of Mr. John Forbes, that if he thought proper to make a gracious present of the same to the King, in that case as soon as he would take possession of the lands which he was to have as a new settler, the Royal title to them would be immediately granted to him, which, otherwise, he was not entitled to, until after having cultivated them for ten years without intermission. The said Forbes insinuated to me, that the proposal had not been disagreeable to the petitioner, who answered, that when in due time, the vessel, with other circumstances relating to it, would be examined, he would then enter into a treaty about it. This is what took place with respect to that business, and this is all the information I have to give your Excellency, in conformity to the superior decree which precedies.

St. Augustine, 8th July, 1812.

JUAN JOSE DE ESTRADA.

DECREE.

St. Augustine, Florida, 8th July, 1812.

Let the Officers of the Royal domain give their information.

KINDELAN.

The Officers of the Royal domain, olserve a notable difference between the exposition of Don Juan Jose de Estrada, having offered to Mr. John Russell, the title of property to the lands which would be awarded to him, in proportion to the number of persons comprising his family, provided he would convey to the Royal domain, the property of the schooner said to be building, from which title it would follow that he would immediately acquire the faculty of disposing of said lands as he would think fit, which otherwise he conld not do, as the Royal title to them would not be granted, until after having cultivated them for ten years together, and proving the same to the satisfaction of the Governor; and the exposition of Russell, saying that 4000 acres more were offered to him, with the faculty of locating them where he choose; but for all that, considering that Russell has every 
appearance of being a settler of good faith, that to all, such lands are granted gratuitously; that a great number of acres are still left unceded, and of course without utility to any body ; considering also the situation in which we find ourselves, and the want of such a vessel as the proposed schooner is said to be, for the service of this port, our opinion is, that after somewhat reducing the number of acres, or in case of a refusal on the part of Russell, to accede to put a reduction, his proposal ought to be accepted in its full extent, with the reserve, however, of what his Majesty may determine, after taking cognizance of the subjects, and with the reserve of what may follow from the survey and her appraisement, made by proper judges of the said vessel.

$$
\text { St. Augustine, Florida, 9th July, } 1812 .
$$

MANUEL LOPEZ.

\section{DECREE.}

Let this be communicated to the interested party, who in his answer, will make known where he wishes to locate the lands he petitions for.

KINDELAN.

\section{Petition to his Excellency the Governor.}

I. Mr. John Russell, a new settler of this Province, with due respect, appear before your Excellency, and being informed of the decrees and informations which have taken place, relative to my annexed petition, say, that as I am not sufficiently acquainted with the lands in this province, it is not in my power to designate precisely, the site of the 4000 acres alluded to in my first petition; but I do promise, without hesitation, to take them out of the vacant lands situated between the head of the river Matanzas, and the river Tomoka, in which territory, the surveyor whom the Governor may appoint, will survey them, in such place or places which I may select, and in which are also located, the lands, which as a new settler, I solicited, which may be seen in my petition recorded in the Secretary's office. As to the notable difference which the officers of the Royal domain observe betwcen my exposition, and the information given by Don Juan Jose de Estrada, it would not have appeared to them so notable, if they had read my first petition with more attentien. In no part of it do I say that 4000 acres of land were offered to me, as said officers will have it. My proposal is clear, plain, and just; besides, as the value of my schooner is greater than that of the lands I solicit in payment for it, for this reason, as I do not accede to the reserve mentioned by the Treasury Department, of submitting ultimately to the decision of a superior authority, I expect to receive the lands at the moment I de. liver up my vessel, in the manner expressed in my petition, and the business will be then concluded. I therefore pray that your Excel. 
lency will be pleased to determine what you may think proper on the subject.

St. Augustine, Florida, 10 th of July, 1812.

JOHN RUSSELL.

\section{DECREE.}

St. Augustine, Florida, 10 th July, 1812.

Let the above proceedings be carried back to the Treasury Department, in order that the officers of the same may make their remarks.

KINDELAN.

\section{INEORMATION.}

Any one, without much meditation being required on his part, will perceive that Russell wishes to have the title of property to two tracts of land, one in payment for his schooner, and the other in his quality of a new settler, according to the number of his family, and that Don Juan Jose de Estrada, spoke only of granting immediately the title of jroperty to the tract which the petitioner had obtained for his head rights, as a compensation for the schooner-but the Treasury Department waives all this, although, at the same time, the officers of the same are surprised at the expressions in which it is attempted to make void their first information, and they are now of opinion, that the vessel may be surveyed and appraised by the King's master ship carpenter or caulker, he being the only judge of such matters in this place, and by the captain of the schooner St. Augustine, Don Miguel Acosta, as soon as he arrives, and who it is expected will arrive in a very short time. However, your Excellency will determine for the best.

St. Augustine, Florida, 11 th July, 1812.

MANUEL LOPEZ.

\section{DECRE E.}

Be it, as it seems proper to the officers of the Royal Treasury, whe will appoint on their part a person to superintend the proposed operations.

KINDELAN.

\section{SURVEY.}

In conformity to the preceding decree, we swent on board of the vessel which is the subject of this transaction; we examined it minutely, also every thing respecting the masts and rigging thereof, and after a consultation as to its value we believe according to our knowledge and conscience, that it is worth 2600 dollars-this being the sum resulting from the inventory which was taken. The whole proceeding took 
place in the presence of Don Tadeo de Arribas commissioned by the Treasurer to superintend the survey and appraisement, in proof which, we sign this document in St. Augustine, Florida, on the 13th July, 1812.

Under my inspection,

TADEO de ARRIBAS, RAFAEL DIAZ,

For Don Miguel Acosta who cannot sign FERNANDO de la MAZA ARREDONDO.

\section{DECRE E.}

St. Augustine, 15th July, 1812.

Let these proceedings be returned to the Treasury Department for such purposes as may be convenient, annex to them the appraisement which has been made in detail of the vessel and its appurtenances, the hull, the sails, \&c. as without such document, it is impossible to judge of the appraisement.

\section{KINDELAN.}

\section{INFORMATION.}

According to the report of good judges the vessel is found with every necessary requisite, is in good state for service, and well calculated to go in and out over the bar of this harbour which is very bad. The schooner which is at this time in the service of the Government, was formerly the launch of the pilot of the bar and for a long time was employed in piloting uessels in and out, it was afterwards rigged as a schooner, is now very old, and is not worth the expense of putting to it a new set of sails, which is much wanted, and would have been sold in the Havana last year if a vessel could have been procured fit to the same service. From these circumstances, from the difficulty of meeting another opportunity as good as this, and from the scarcity of specie in the Royal Treasury, it appears that we are justified and authorized to take advantage of this opportunity without waiting for the decision of His Majesty, who it believed will approve it, as soon as he is well informed of the whole But your Excellency will determine what you may deem most proper, the officers of the Department of the Royal Treasury abstain from speaking about lands, as the Royal orders which regulate these matters have never been communicated to them, as they are not acquainted with the locality of those which Russel petitions for, as they do not know whether the same are or are not claimed by some other persons, as they are ignorant of their value, although this cannot be great, when there is still so much land unoccupied and distributing gratis. 


\section{APPRAISEMENT.}

In conformity to the decree of His Excellency the Governor of this place, dated this day, relative to the transactions with John Russell, a settler of this Province, the following appraisement has been formed by the master ship carpenter, Don Rafael Diaz and Don Miguel Acosta, captain of the King's schooner the St. Augustine, under the inspection of Don Tadeo de Arribas, commissioned by the Treasurer Don Manuel Lopez, Comptroller of the Royal Treasury; of the schooner called the Perseverance, commanded by Don Thomas Forrest, owned by the children of the said Russell, to wit:-

For the Hull of the schooner, which measures from head to stern 34 feet $2 \frac{1}{2}$ inches, 16 feet and $\frac{1}{2}$ inch beam, her hold 5 feet 10 inches deep and $58 \frac{1}{2}$ tons burthen, with her two masts, yards, bowsprit, topmasts, \&c.

Here follows the appraisement of the apparcl and furniture of the schooner, which, with \$1938, the sum which the vessel, masts, yards, \&c. is valued at, makes the amount of the appraisement at \$2600.

St. Augustine, 15th July, 1812.

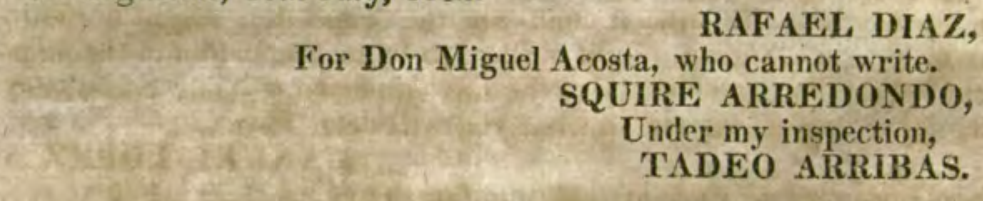

\section{DECREẼ.}

St. Angustine, 17th July, 1812.

I approve the opinion of the officers of the Treasury Department, and in conformity thereto, let the bargain relative to the said schooner be concluded with every requisite formality, and let the title of property be given to John Russell, to four thousand acres, in that part of the country he indicates in his last petition.

KINDELAN.

\section{PeTrTion.}

To His Excellency the Governor:

I, John Russell, a new settler of this Province, with due respect. appear before your Excellency; I say, that knowing the purport of your Excellency's decree, which follows the proceedings concerning my said schooner Perseverance, to which I gave my assent, I expect at the same time to receive the titles of property to the land which have been granted to me as a new settler, of which I make mention in my first petition, in consequence of which, I beg your Excellency to order that the title of property to the fonr thousand acres, which $I$ am to receive as a consideration for my schooner, and the title of property to the lands granted to me as a new settler, be given to me at the same time. 
DECREF:

Let the Treasury Department inform on the subject.

KINDELAN.

\section{INFORMATION.}

In the first petition which Russell presented on the 8th instant, he offered his schooner on the condition, that he would receive for it the title of 4000 acres, and also the title of property to the lands, which as a new settler he had petitioned for, proportioned to the number of his family ; and the decree of your Excellency of yesterday refers only to the 4000 acres, the price of said schooner.-The officers of the Treasury are ignorant of the import of John Russell's petition, as they have already said, and say again that they are as yet unacquainted with the Royal orders by which such matters are regulated; but it appears to them that if the title of property may be given to the petitioner to 4000 acres in consideration of his schooner, the same may be given also for his other lands as a new settler, particularly as we understand that without that condition the proposition might be withdrawn, but such a grant ought always to be in proportion to the number of his family, and the slaves he has imported.-Your Excellency will, nevertheless, determine what you will deem best.

MANUEL LOPEZ.

St. Augustine of Florida, 17th of July, 1812.

DECREE.

St. Augustine, 20th July, 1812.

Let the above be communicated to the interested party.

KINDELAN.

\section{Petitiox.}

To His Excellency the Governor:-

I, John Russell, a new settler in this Province, with due respect appear before your Excellency, and having received notification of the information of the Treasury Department, and of the decree of your Excellency annexed to it, say that, as all the timbers of my schooner are mahogany, it is worth at least 5,000 dollars, although the surveyors, appointed to survey and appraise her, have limited its value to two thousand and six hundred dollars-this difference is owing to their not having considered the intrinsic value of mahogany, and that of pine and other inferior timber, which do not cost half the money, nor require half the labor which the malıgany does.- Therefore, the genuine value of said schooner ought to be considered equivalent to 5,000 dollars, and I would not take less for her, if I was to be paid in cash-at the same time, I have to observe to your Excellency, that, during the war between Great Britain and the United States, it will 
be impossible for me to impart in this Province the rest of my slaves, and considering the difficulty of exporting negroes from Bahama Islands, I shall want at least twelve months, from the time the said war is concluded, to take away my slaves; and as I wish to invest the greater part of my property in negroes, I have to beg your Excellency to delay giving me the title to the lands which I petitioned for on the 22d June of last year, until the conclusion of the term mentioned, and as soon as this is granted to me, together with the title of property to the 4000 acres of land, already decreed by your Excellency on the 16th instant, and that in case said lands could not be found in the place mentioned, when the surveyor shall have to survey them, they may be located in the part known under the name of Twelve Mile Swamp. I am ready to deliver, faithfully, my vessel to the Governor. Therefore, I beg your Excellency to accede to this my petition, and order a certificate of the document which will be drawn to that effect, be given to me, to serve me as a guarantee.

JOHN RUSSELL.

St. Augustine of Florida, 22d July, 1812.

\section{DECREE.}

St. Augustine, 22d July, 1812 .

Let this be communicated to the Comptroller of the Treasury together with the document shewing the oath of fidelity and allegiance which John Russell took before my predecessor, with every thing relating to this business.

KINDELAN.

\section{INFORMATION.}

Mr. John Russell declared, on the 10th of June, 1811, that he had in Providence a schooner 62 tons burthen, worth $\$ 6,000$ with all her apparel, and 100 negroes, and that he wished to import the whole to this province ; that, in the same place, he had landed property to the amount of $\$ 15,000$, nineteen horses, four hundred sheep, and sixty head of cattle. He has now brought property to the amount of $\$ 7,00487 \frac{1}{2}$ in effects, house furniture, sheep, and horses, including his schooner, valued, as he says, at $\$ 5,000$; he has brought also his wife and children, and eighteen slaves. What he petitions for now, appears to be reasonable to the officers of the Treasury Department; and that the title of property may be given to him now according to the number of his family, he presents, together with the title to 4,000 acres already granted him for his schooner, and keep in reserve for him for the space of ten or twelve months after the conclusion of war between Great Britain and the United States, the land eontiguous to the first grant, in order to enlarge it in proportion to the number of hands he will import; and not grant the said lands reserved for John Russell to any body else, although petitioned for, until the expira- 
tion of the stipulated period, and then only the Governor will be at liberty to grant the said reserved lands to any body they please, in case John Russell should not have completed the importation of what he has mentioned in his declaration. If your Excellency agree that, in conformity to this opinion, the said titles of property may be grantedto the petitioner, you will be pleased also to order the delivery of the said schooner to Captain Miguel Acosta, with all the articles mentioned in the inventory, and whatever may belong to the said vessel, and might not have been included in said inventory, and would be necessary for the navigation of the same, and also the delivery of a certified copy of all the proceedings to the petitioned, according to his wish.

St. Augustine, Florida, 25th July, 1812.

MANUEL LOPEZ.

\title{
OATH.
}

I, Don Tomas de Aguilar, Secretary pro tem. of this Government, certify, that in the book No. 10 , in which are registered the oaths of fidelity which the new settler takes, the oath taken by John Russell is registered in the second folio, the tenor of which is as follows :

"In the city of St. Augustine of Florida, on the 10th of June, 1811, before his Excellency the Governor pro tem. of this place and province, the Lieutenant Colonel of the army, Don Juan Jose de Estrada, appeared Mr. John Russell, born in South Carolina, at the time it was a possession of the British crown, married and having five children, three of whom between sixteen and twenty-five years of age, and the other two above eight years old, ship carpenter by trade, but now dedicates himself to agriculture, and of the Protestant persuasion, under which, and with every form required by law, took the oath of allegiance in the presence of the Secretary deceased, and pro. mised to keep fidelity, and remain a faithful vassal to our sovereign the Lord Don Ferdinand VII, and to be faithful to the authorities constituted in his name, to bear arms in the defence of the province, against any enemy that would intend to invade it, and submit entirely to the laws of the kingdom." After having taken said oath, he took another relating to his property, and said, that in the harbor of Providence, he has a schooner of sixty tons, which he values at 85,000 , and a parcel of sails and rigging worth about $\$ 1,000$; one hundred negroes in Nassau, eighty of whom are above sixteen years old, and the remaining from eight to sixteen years old; also landed property to the value of $\$ 1,500$ situated in said place of Nassau, nineteen horses, 400 sheep, and sixty head of cattle, the whole of which, or the value thereof, he intends to import to this province, and dedicate himself to agriculture, and he signed the same with his Excellency the Governor and the aborementioned office, and which I affirm.

\author{
ESTRADA, \\ JOHN RUSSELL, \\ TOMAS DE AGUILAR.
}


Before me, Jose De Zulezarreta, Notary of the Government. And in conformity of the preceding decree, $\mathbf{I}$ deliver the present copy in St. Augustine, on the 28th July, 1812.

\section{TOMAS DE AGUHLAR.}

\section{Petition to his Excellency the Governor.}

Mr. John Russell, a new settler of this province, with due respect, appears before your Excellency, and says, that he has taken the oath of fidelity and allegiance to his Catholic Majesty, with the sincere intention to dedicate himself and the slaves he has manifested in the solemn act of his oath, to the agriculture, and all the slaves whom he may acquire with the proceeds of the land and other property which he has declared he owned in Bahama Islands; and in order to realize the said project in its due time, he humbly begs your Excellency to be pleased to grant to him 1200 acres of uncleared lands, situated west of the river Halifax, bounded north by lands granted to Mr. Farquhar Bethune, and south by lands also granted by Mr. Patrick Dean, and 3.000 acres as the complement of what he is to have according to the number of his family and slaves, north of the mouth of the river Tomoca, or where it is limited by the said river Halifax, bouncied south by lands granted to Mrs. Russell Ormond, widow of James Ormond, running north, and including both sides of the Smiths road, until the point which will terminate the lands petitioned for, and says he conforms himself to what his Majesty may please to determine, as to the quantity allotted, and the conditions of the grant; the whole of which is a favor which he expects to receive from the known justice of your Excellency.

St. Augustine, Florida, 19th June, 1811.

\section{JOHN RUSSELL.}

\section{DECREE.}

Reserving to act on the petition of John Russell at the time he sliall have imported the property he bas sworn to, let the officers of the Secretary's office, where the said petition will be kept in reserve until said period, inform the petitioner of the method adopted, and the conditions prescribed by this Government in grants of a similar nature, and to the whole of which due attention will be paid with respect to the grants now in question.

ESTRADA, QUINTANO.

I, Thomas de Aguilar, Secretary pro tem. of this Government, do certify that the preceding copy is faithfully drawn from the original, which remains in the Secretary's office under my charge, and, in conformity to the decree of His Excellency, I deliver the present, in St. Augustine, of Florida, 28th July, 1812.

THOMAS DE AGUILAR. 
DECREE.

St. Augustine, 28th July, 1812.

In consequence of those proceedings, and of the information of the Comptroller of the Treasury, relating to the acquisition of the schooner, proposed by John Russell to the Government in exchange for vacant lands, it is hereby declared, that the said Russell is lawfully and absoJutely proprietor of 675 acres of land, to be in the vacant lands west of the river Halifax, bounded north by lands granted to Mr. Farquhar Bethune, and south, by others also granted to Mr. Patrick Dean; according, the said number of 675 , to the family which Russell now presents, at the rate of 50 acres to himself, and the same number to his wife, both being head of family, and 25 acres for every one of his five children and eighteen slaves, according to the customary rule observed in granting lands; and a reserve will be made, but no grant will be given of 2,050 acres, which will be the complement for the one hundred slaves which he said he would import; which reserved lands will be granted in proportion to the number of hands he will import. Said reserve will have its full force for the space of ten months, after the conclusion of the present war between Great Britain and the United States of America; and, in the case of John Rtssell, in the specified time, had not imported more hands, then the Government will be at liberty to dispose of said lands as they please. It is also hereby declared, that John Russell is equally absolute proprietor of the 4000 acres of land mentioned in my decree of the 16th instant, situated between the Matanzas and Tomoca rivers. And, in case that, at the time the surveyor will go and survey them, the said number of acres will not be found, let it be completed in that uncleared tract called Truelve Miles Swamp; and, after ascertaining the measurement and boundaries, which cannot be known now, the title of property will be granted to John Russell, and, in the interim, the certificates he solicits will be to him as an equivalent of the titles in form, and he will receive said certificate from the witness and assistant, Don Juan de Entralgo and Don Bernardo. Jose Sequi, as the only notary of the Government of this City and Province is very sick. Let this determination be made known to John Russell, in order that. in virtue thereof, he deliver the schooner to the officers of the Royal Domain, and with her, all her appurtenances, of which the Treasury Department will receive due notice. Let it be understood, that said schooner will henceforward becalled the Barbarita, and will be manned by a captain, a pilot, a boatswain, and three sailors. Let a consultation take place to determine the precise salary of every one of them; and let this be communicated to the officers of the Royal Treasury, that they may carry it into effect.

KINDELAN.

(Here this part of the record contains irreievant matter.). 


\section{PETITION.}

To His Excellency the Governor:

Mr. Joln Rinssell, a new settler of this Province, respectfully represents to your Excellency, that, as he is entitled to 4000 acres of land, situated between the rivers Matanzas and Tomoca. which the Government thought fit to grant him, in exchange for a schooner, to him beionging; and, also, to 675 acres of land west of the river Halifax, correspending with the number of persons composing his family, and which he manifested in his oath when he was admitted as a new settler, with the reserve that said grant would be increased after completing the introluetion of his slaves; and, as he wishes to have the said two tracts surveyed, and as there is no surveyor general in this place to do it, he begs your Excellency may be pleased to authorize to that effect Mr. William Lawrence, who is acquainted with the profession, and has performed the duties of it in the case of other persions; and the petitioner doubts not that he will receive this favor from the well known justice of your Excellency. St. Augustine, of Florida, 19th February, 1812.

JOHN RUSSELL.

DECREE.

St. Aggustine, 1st March, 181 S.

Let the Comptroller's Office inform on the subject.

KINDELAN.

\section{INFORMATION.}

In the decree of your Excellency, dated on the 28th of July, 1812, it was ordered to give to Mr. John Russell, a copy of the whole proceedings relating to the mentioned lands, in order that the said copy should serve him as an equivalent of the titles of property which would be given to him in due form, as soon as the said lands conld be surveyed, the measurement and boundaries being unknown at the said date; in the same decree, it was ordered to keep in reserve, for the use of John Russell, until ten months after the conclusion of the present war between Great Britain and the United States of America, as much land as corresponded to the complement of one hundred negroes, whom he declared he woull import; after which, the Government was to be at liberty to dispose of said lands, in case that the petitioner should not then have brought a greater number of hands. Considering the alove circumstance, and considering also, that every time Russell would bring in more hands, the survey should be repeated, it appears, that, as the copy he has obtained is equivalent to the title itself, the want of which cannot be prejudicial to him, as in such a case the Government should interfere in his behalf, it is proper to wait until the said epoch of ten months after the conclusion of the war between the mentioned powers, and then at once survey and assign the bounda- 


\section{[Doc. No. 115.]}

ries of such lands, as the petitioner will be then entitled to; and let a copy of this, and of the decree which will follow, be given to him, if he requires it, in order that he may at all times prove his desire to obtain the titles. But your Excellency will determine as you think proper, whether the survey ought to take place now, or be delayed, so that the interested party be best satisfied, as the 'Treasury Department is deficient in the knowledge of these particulars.

St. Augustine, 10th March 1813.

\section{MANUEL LOPEZ.}

\section{DECREE.}

St. Augustine, 10th March, 1813.

I.t it be done, in conformity to the opinion of the Comptroller, therefore let the copy called for by the officer, be drawn by Don Juan Entralgo, and Don Jose Bernardo Sequi, who, after having accepted the commission, and sworn to the fulfilment of it, will serve as witnesses and assistants, in lieu of the Notary; and all this being done, let it be annexed to the former proceedings, and delivered to the interested party.

KINDELAN.

\section{PETITION.}

\section{Petition to His Excellency the Governor.}

Don Josc Mariano Hernandez, a planter, of this Province, with due respect to your Excellency, represents, that, for reasons which may be important to him, it is necessary to him that the annexed document in the English language, should be translated into the Spanish idiom, and to that effect he begs your Excellency to be pleased to order the translation to be made by a capable person; after which, that the original be returned to him, and he will promptly defray the expenses attending it, This favor he expects from the justice of your Excellency.

St. Augustine of Florida, 31 st January, 1820.

JOSEPH M. HERNANDEZ.

\section{DECREE.}

\section{St. Augustine, 1st February, 1820.}

The presentation of the annexed document is acknowledged, and as there is no public interpreter, let it be translated by Don Bernardo Sequi, who is capable to do it: let his acceptation and oath be previously received before the present Notary; and after it is done, let the information of it be given.

COPPINGER.

Before me, Juan de Entralgo, Notary of Government, St. Augustine, on the same day, month, and year, I notified the preceding decree to Don Jose Mariano Hernandez; to which I certify.

ENTRALGO. 
NOTLFICATION AND OATH OF THE INTERPRETER.

On the same day, I notified to Don Bernardo Sequi the appointment of interpreter, given to him in said decree, who, after having taken cognizance of it, said he accepted, and did accept it, promising under his oath, legally taken, to exercise well and faithfully the functions of his charge to the utmost of his understanding and knowledge, and signed the same-to which I certify.

Before

BERNARDO SEQUI. JUAN DE ENTRALGO.

\section{POWER OF ATTORNEY.}

TRANSLATION.

\section{$\left.\begin{array}{c}\text { Georgia, } \\ \text { Glyinn County. }\end{array}\right\}$}

Be it known that I, Mary Russell, of the State and County aforesaid administratrix of John Russell, formerly an inhabitant of the Province of East Florida, in virtue of various causes and considerations, which move me thereunto, have appointed, ordained, authorized, and elected, and by this do appoint, ordain, authorize, and elect, Mr. Jose M. Hernandez, of the Province of East Florida, my true and legal attorney, in order that for me, and in my name, and for my personal use and benefit, may ask, demand, present himself to collect and receive all such sums of money, debts, and other claims, that might be due to the estate of my deceased husband, and to make use in my name of all the means the law requires to obtain the recovery of the same, to attach if necessary, or to compromise and liquidate with the corresponding and sufficient discharge; and in order that he may proceed for me in all my affairs and legal acts, with the necessary latitude, in the same manner as if I was personally present, appoint attorneys under him and revoke them as he thinks fit; and give to the said my attorney, the most ample faculties which in right belongs to him as such. In testimony thereof, I sign and seal the present power, on the 16th December, 1819, and in the 44th year of the Independence of the United States of America.

MARY RUSSELL.

Acknowledged, signed, and sealed, in our presence,

GEORGE MARCH, Justice of the Peace.

T. ABRAHAMS, Notary Public of Glynn County.

The preceding translation is well and faithfully made, according to the best of my knowledge and understanding, and I refer to the original thereof; and i: conformity' to the superior mandate, I draw and sign it in St. Augustine of Florida, on the Sd February, 1820. 
DECREE.

St. Augustine, February sd, 1820.

I have seen the preceding translation, and let the same be communicated to the petitioner, for his legal purposes.

Before me, COPPINGER. JUAN DE ENTRALGO.

\section{NOTIFICATION.}

St. Augustine on the same day, month, and year, I notified the present decree, to Don Jose Mariano Hernandez, which I certify.

ENTRALGO.

\section{PETITION.}

Don Jose Mariano Hernandez, a planter of this Province, respectfully represents to your Excellency, that the documents and the translation thereof annexed, prove that he is fully authorized by Mrs. Maria Russell, widow and administratrix of Mr. John Russell, formerly an inhabitant of this Province, to attend to all the business which he left undecided in it, and as he must always have before him said instrument for the legal uses of his commission, and in order that the same may not be mislaid, the petitioner begs your Excellency may be pleased to order the present Secretary to give him a certified copy of the power aforesaid, and to record the original thereof in the public archives, there to remain safe against any accident; therefore, may it please your Excellency to provide in conformity $t$, this petition; which/ favor is expected from the known justice of your Excellency.

St. Augustine, sd F'bruary, 1820.

JOSEPH M. HERNANDEZ.

\section{DECREE.}

St. Angustine, 4th February, 1820.

Granted.

COPPINGER.

Before me, JUAN DE ENTRALGO.

NOTIFICATION.

St. Augustine, on the same day, month and year, I notified the preceding decree to Don Jose Mariano Hernandez, which I certify.

ENTRALGO.

It is conformable to the originals, which remain in the archives under my charge, and in obedience to superior orders, I seal and sign the present certified copy in St. Angustine of Florida, on the 5th of February, 1820.

JUAN DE ENTRALGO. 


\section{Petition to his Excellency the Governor.}

Don Jose Marian Hernandez, a planter of this province, in his capacity of attorney of Mrs. Maria Russell, widow and administratrix of Mr. Jolnn Russell, as it is proved by the power duly annexed, with due respect, represents to your Excellency, that, in the year 1812, the Governor admitted, as a new settler of this province, the said Russell, deceased: he brought to this place from the Island of New Providence, as part of his property, a schooner, which he proposed to convey to the Treasury Department, in exchange for 4000 acres of land, and the title of property to such as were granted to him in proportion to the number of his family and slaves, in his quality of a new settler; and the Governor having acceded to the said proposition, as it is proved by the documents recorded in the Secretary's office, he petitioned that the 4000 acres, granted for the consideration of said schooner, might be located and surveyed between the rivers Matanzas and 'Tomoco, which so essential a requisite did not take place, for reasons detailed in said proceedings, in which the Governor offers to interfere in his behalf, against any other claimant, in order that, in case a sufficient number of acres could not be found unlocated in the place aforesaid, he may be entitled to complete the same in the swamp called the "Twelve Mile Swamp." The said John Russell having taken sick and died in Fernandina, his widow met with many difficulties, to import the remainder of the slaves, whom she owned in New Providence, and lost by that, the hope of obtaining more lands than those which were granted to them at the time of their emigration to this province, and by the same reasons, was prevented from petitioning again for the location and survey of said lands; which location and survey are indispensable circumstances, although she considers herself as the absolute proprietor of said land, in virtue of the proceedings aforesaid. Therefore, she now petitions that the said location and survey may be carried into effect, in the place designated by the surveyor, Don George Clark, who is now in this city; and she begs your Excellency to order, in conformity to her petition; which act of justice she expects from the correct administration of your Excellency. "

St. Augustine, 8th of February, 1820.

JOSEPH M. HERNANDEZ.

\section{DECREE.}

Let the power of attorney which has been presented, be annexed to the proceedings referred to, and let the whole be presented agaii:.

Before me,

COPPINGER.

JUAN DE ENTRALGO, Notary of Government.

NOTIFICATION.

In St. Augustine, on the same day, month, and year, I notified the preceding decree to Don Jose Mariano Hernandez; which I certify. ENTRALGO. 


\section{DECRER.}

St. Augustine, 11th February, 1820.

Having seen, let the survey, as solicited, be made by the surveyor, George Clarke.

Before me,

COPPINGER.

JUAN DE ENTRALGO, Notary of Government.

\section{NOTIFICATION.}

In St. Augustine, on the same day, month, and year, I notified the preceding decree to Don Jose Mariano Hernandez; which I certify,

ENTRALGO.

\section{Petition to his Excellency the Governor.}

Don Santiago Russell, an inhabitant of this province, with due respect represents to your Excellency, that, for the purposes which may be convenient to him, he finds it necessary that, by the interpreter whom your Excellency may authorize to that effect, the annexed English document may be translated into the Spanish language; therefore he begs your Excellency may be pleased to order the same to be done, and he will pay the expense thereof.

Florida, 1 sth June, 1821.

\section{JAMES RUSSELL.}

DECREE.

St. Augustine, June 13, 1821.

The annexed document is presented, and as there is no public interpreter, let the translation be made by Don Bernardo Serui, after his having accepted and sworn to his commission; and when done, let it be brought forward.

Before me,

COPPINGER.

JUAN DE ENTRALGO,

Notary of Government.

NOTIFICATION.

In St. Augustine, on the same day, month, and year, I notified the preceding decree to $\mathrm{Mr}$. James Russell, to which I certify. 


\section{NOTIFICATION, ACCEPTATION, AND OATH.}

On the same day I notified to Don Bernardo Sequi the appointment iof interpreter given to him, and he said that he accepted it, and did accept_it, promising, under his legal oath, to exercise well and faithfully the functions of his commission, according to his best knowledge and understandiug, and signed. To which I certify.

\section{Before me,}

BERNARDO SEQUI. JUAN DE ENTRALGO.

TRANSLATION.

\section{IsLAND of BaHAMA, New Providence. $\}$}

In the name of God, amen : I, John Russell, of the island of St. Salvador, do give, make known, and declare this to be my last will and testament. I give, bequeath, and leave, all the property, real and personal, I may possess in these islands, in the State of Georgia, and any where else, to my consort, Maria Russell, and to my children, Isabel Russell, James Hunter Russell, William Edward Russell, Richard Henry Russell, Maria Amelia Anna Russell, and to any other child my consort aforesaid may have by me in future, for them or their survivors, to have and to hold said property in equal parts and proportions, subject to the directions, limitations, and restrictions, which will be detailed, to wit :

It is my will that all my property be united and managed under the directions of my executor or executors, who will be named, in the most advantageous manner, for the benefit of all my legatees aforesaid, until the youngest surviving child be twenty-one years old, if it is a male child, and eighteen years old, if it is a female, and then an equal division of my property will take place among the survivors; and should any of my children, during the minority of the youngest, marry, or should any other circumstance occur which would make it necessary to appraise sail property, I charge and authorize my executors, in behalf of my children, to pay the most prudent attention, so that every one may have their due proportion, and to that effect to appraise the peoperty according to the circumstances of the times; I leave undivided the remainter of the propicty belonging to the other legatees; and I declare that it is also my wish, that should any of my children die, and leave after them lawful heirs, the said heirs shall have the portion due to the deceased; otherwise, said portion will be added to the common stock, and belong to the surviving legatees. I do elect and appoint as my executors and executors of this my last will and testament, my consort aforesaid, my son, James Hunter Russell, and Robert Leach, of the State of Georgia ; and I do hereby revoke and annul whatever other disposition I may have made before this moment. In testimony of which, I, John Russell, testator aforesaid, do sign and seal this instrument on the 18th January, of the year of our Lord 1811. JOHN RUSSELL.. 
Signed, sealed, made known, and declared by John Russell, testator aforesaid, to be his last will and testament, in our presence; and at his request, in the presence of all of us, we have subscribed our names.

\section{John Armstrong, \\ David Bethel, $\}$ Witnesses. \\ J. T. Thомpson, $\}$}

Fernandina, 1st August, 1814.

The preceding will has been opened in our presence.

FELIPE R. YOUNGE, FARQUHAR BETHUNE.

\section{Secretary's Office, ? Glynn County. $\}$}

Registered in the book D, folio 16, this day, 31st of May, 1815 . T. ABRAHAMS.

\section{$\left.\begin{array}{l}\text { Georgia, } \\ \text { Glynn County. }\end{array}\right\}$}

Before me, P. Gibson, Magistrate in said County, personally appeared Mr. John Armstrong, of the islands of Bahama, now a resident in the State of Georgia, who, being duly sworn, declared that the said John Russell signed, sealed, made known, and declared the preceding instrument to be his last will and testament, and that witness, together with David Bethel and F. J. Thompson, subscribed their names thereto, having been called to witness the same. Witness also declares, that when the testator aforesaid executed said will, he was in a good state of health, and enjoying the mental faculties unimpaired.

JOHN ARMSTRONG.

Sworn to before me this 4th day of May, 1815.

P. GIBSON, $\boldsymbol{J}$. $\boldsymbol{P}$.

The preceding translation is well and faithfully made, according to my best knowledge and understanding, for which I refer to the original; and, in conformity to superior opders, I sign the present in St. Augustine of Florida, on the 14th June, 1821.

BERNARDO SEQUI.

\section{DECREE.}

St. Augustine, 14th June, 1821.

Let the preceding be delivered to the petitioner, who will use it according to right.

Before me,

COPPINGER. JUAN DE ENTRALGO.

\section{NOTIFICATION.}

In St. Amgustine, on the same day, month, and year, I notified the preceding decree to Mr. James Russell, which I certify.

ENTRALGO. 


\section{PETITION.}

Mrs. Maria Russel, a new settler of this Province, in the proccedings that have occurred before the tribunal of your Excellency, relating to 4000 acres of land, granted as an equivalent of the vessel which my husband, deceased, sold to his Majesty, for the public service of this place, which vessel was then called the Perseverance, and afterwards, the Barbarita, and to 675 acres, which were granted agreeably to the number of our family, and of the slaves whom we imported into this Province, in the most proper form my right may require, which right was acknowledged by the act of the Governor, dated 28th July, 1812, which comprehends the two grants aforesaid, appear before your Excellency, in the person of my Attorney, and say, that, in consequence of my petition having been acceded to, as appears by said act, dated 11 th February, 1820. I took the necessary measures, to ascertain the survey of the wooded lands to be found in the territory, situated West of the river Halifax, bounded North by lands belonging to Mr. Farquhar Bethune, and South by the lands belonging to Mr. Patrick Dean, where the 675 acres belonging to my family are to be located, and the 4,000 acres to be located from the head of the River Matanzas to the River Tomoco, as more minutely explained in said act, dated 28th July, 1812 ; but it happens, that after the Surveyor, Mr. George Clark, had taken the points my deceased husband fixed upon in conformity to the grants, that at all times they may serve as the basis of the survey which the superior decrees declare in the most ample manner ought to be favorably made in behalf of the grantee, I find. that within the limits of the points alluded to, the Governor has granted four tracts, to wit: one of 800 acres to Mr. Isaac Wicks; one of 1100 to Mr. P. Lynch: one of 500 to Mr. James Dailey, and another of a smaller size to Mrs. Mariana Wicks. Therefore, in addition, that these new grantees, in no case whatever, can or ought to prejudice my right, as their grants are subsequent to the conclusion of my contract with the Governor, and as my singular, extraordinary, and privileged requisition, cannot have any relation, or meet with any competition, with any of them, except that they ought to be ejected from their assumed points; I will offer to your Excellency other short reflections, by which your Excellency will see, that in the case I should wish to occupy the vacant lands they have left, my acquisition would be illusory, as said lands are of no value whatever, as it appears that these new grantees have located their grants in the only spots that would give a value to mine, which, without doubt or equivocation, is to consist of wooded lands, for which very reason, the Governor, in case $\mathbf{I}$ should not find the complement of my lands in the wooded parts of it for the cultiration L-tween the two rivers aforesaid, gave me the right of completing my said grant in the wood known by the name of Twelve Mile Swamp, in order that my contract with the Governor might be fulfilled in all its parts.

Neither the series of vicissitudes which have prevented to carry 
into effect the survey and ixing the boundaries as it is indicated in various parts of the proceedings, can, it appears to me, interrupt my rights to said wooded lands, and this is proved sufficiently without ad lacing others by the two particulars already exposed, which I consider as decisive, as they cannot be contested by the four new grantees neither do I consider that against both exceptions, the right sense of justice which distinguishes your Excellency, can oppose a determination which may be contrary to the acts of your worthy predecessors. Therefore, with due reverence I beg your Excellency be pleased to acknowledge this my presentation, together with a draft, simple, but conformable to the original. which shews that the boundaries which correspond with my grant, comprehend within them the possessions aforesaid, in order that in consideration thereof, and of all that has been exposed. your Excellency be pleased to order that the grantees aforesaid yield to my right; and in order to obtain this end. I hope that your Excellency will have the goodness to order, with a view that the interested parties may have the shortest notice of it, that the Secretary of this Government do notify a certification of the royal order obtained in approbation of $\mathrm{my}$ said contracts, the whole of which appears to me agreeable to justice in general. and in particular to that which distinguishes your administration; and 1 swear that I do not proceed from malice, \&c. Morcover, in order to legalize my lawful representation as it ought to be, 1 beg your Excellency be pleased to order the notary in this cause, who is the only one employed in this Government to annex to the proceedings a certificate of the substitution of power granted by Don Jose Mariano Hernandez, and also to acknowledge the presentation of the certificate of the will which is duly annexed to it. I claim justice ut supra.

JAMES H. RUSSELL.

DECRER.

Let it be communicated to the Auditor of War.

St. Augustine, 14th June, 1821.

Before me, JUAN DE COPPINGER.

NOTIFICATION.

In St. Augustine, on the same day, month, and year, I notified the preceding decree to Mr. James Russell, which I certify.

ENTRALGO.

PETITION.

Mr. James Russell, an inhabitant of this Province, in his capacity of a lawful heir and executor of Mr. John Russell, deceased, in continuation of the proceedings, the object of which is to claim certain lands alloted to his father aforesaid; and in order to proceed in other particulars in the best legal form, appears before your Excellency, 
and says, that, in order to produce a greater proof of what is asserted in the proceedings, although the survey of said lands has been prevented by a variety of circumstances, which have been mentioned, still I can do it now with propriety, in observing when I take possession, to draw a line north and south, on the road which, west of this place, leads to the territory of Mosquitos, stopping on the N.N. W, to the S.S.E. and re-marking a pine tree, north, on the boundary line of Mr. Francis Pellicer, and another, south, on the boundary line of Mr. Ormond's land, from which two points, both marked B. R. the lines had to run east, in order to embrace Mr. John Russell's property ; therefore, I hope your Excellency will be well pleased to order the admission of such witness as I am ready to produce, who under their legal oaths, will declare whether or no, whatever I have related is certain, from which the spoliation, the grantee has suffered in his absence, will evidently appear; und in consideration of all which, your Excellency will be pleased the restitution be made to me in toto: Therefore, I supplicate your Excellency to provide, in conformity to my petition, the object of which is a necessary requisite which ought to precede the issuing the titles of property which are wanting, as a matter of form. I claim justice, moreover, as some witnesses are to be examined who are not acquainted with the Spanish language, I pray your Excellency to be pleased to appoint an interpreter, to make the necessary translations. I claim justice, \&c.

St. Augustine, 16th June, 1821.

JAMES RUSSELL.

\section{DECREe.}

St. Augustine, 16th June, 1821.

As to the first and principal point of the petition, let the information offered, be admitted acrording to law, and lét the witnesses appear and make their declaration before the Auditor of War, and according to the merits of the case, I will dispose what is most convenient; and, as to the second point, as there is no public interpreter, let Don Bernardo Sequi be appointed, he having previously accepted the oath of office.

Before me,

COPPINGER. ARREDONDO. JUAN DE ENTRALGO.

\section{NOTIFICATION.}

On the same day, month and year, I notified to Don Bernardo Sequi, the appointment of Interpreter given to him, on which he said that he accepted and he did accept it, promising on his oath legally taken, to exercise well and faithfully, the functions of his commission, according to the best of his knowledge and understanding. And - signed, which I certify.

Before me,

BERNARDO SEQUI.

JUAN DE ENTRALGO. 


\section{Declaration.}

In the city of St. Augustine, Florida, on the 16th of June, 1821, before Don Juan de Arredondo y Santilices, Auditor of War of this place and Province, appeared Mr. Robert McHardy, an inhabitant and planter of the same. married, who in the hands of the Auditor, before me, Notary, and through the organ of the interpreter, Don Bernardo Sequi, made oath in a legal form and promised to tell the truth in all he might know, relating to the questions that will be put to him, respecting the case and the meaning of the representation which precedes, and said, that, in the year 1813, he accompanied Mr. James Russell when he went with some of his slaves to take possession of the lands which this Governor had given him, in consideration of the Schooner Barbarita, and in his capacity of new settler, between the rivers. Tomoco and Matanzas, in which place Russell himself designated the limits, by marking some trees with letters, which still exists, and affirmed that what he has said is the truth; that he is forty five years old; that the law exceptions which have been made known to him, do not affect him; and his declaration having been read to him he affirmed and signed it, together with the Auditor and the Interpreter, which I certify.

ROBERT MCHARDY,
BERNARDO SEQUI.
Before me,
JUAN DE ENTRALGO.

\section{DECLARATION.}

In continuation appeared Don Francisco Pellicer, an inhabitant of this place, married, who, in the hands of the Auditor, before me, the Secretary, took his legal oath, promising to tell the truth in all what he might know relating to what he may be interrogated upon, relating to the same business, said, that he has seen the marks of letters which are found on two trees, one on tie East, and the other on the West, which two points embrace the wooded land which is situated between the rivers Matanzas and Tomoco, where this Government granted lands to the deceased Mr. John Russell, which marks, as witness has been informed by his own children, were made by $\mathrm{Mr}$. John Russell himself, as a mark of the limits and boundaries which were to enclose said granted lands: that this act of John Russell is of public notoriety, as well as his going personally with his slaves to do it. Witness says, that what he has deposed is the truth; that he is sixty-seven years of age; that the law exceptions do not affect him; and he signed his deposition. The Auditor affixed his flourish, which I certify.

Before me, A flourish.

FRANCISCO PELLICER. JUAN DE EN'TRALGO.

\section{DECLARATION.}

In continuation appeared Don Jose Mariano Hernandez, one of the members of the Constitutional Council of this place, who, before me, 
the Secretary, took his legal oath, promising to tell the truth, in all he might knew upon which he might be interrogated, relating to the representation of Mr. James Russell, and said that, on the wooded lands situated between the rivers Matanzas and Tomoco, he has seen some trees marked with initials, which operation, he knows, from public notoriety, was made by the deceased Mr. John Russell, at the time that he went with his slaves, to mark the limits and take possession of the lands which he obtained from this Government in exchange for a schooner which he sold to the Revenue Department and of those lands which were awarded to him as a new settler; and witness has no doubt; that the deceased John Russell, aforesaid. went on the mentioned lands, with said intent, and that this happened immediately after he was declared the owner of said lands, and witness says, under his oath, that all this is the truth; that he is thirty-three years of age, and signed his deposition; and the Auditor put his flourish, which I certify.

One flourish.

Before me,

JOS. M. HERNANDEZ. JUAN DE EN'TRALGO.

ACT.

St. Adgustine, 18th June, 1821.

Seen the preceding, and Mr. James Russell having proved that he is a lawful son and heir of the deceased Mr. John Russell, and of the age of twenty-five years, lie is hereby considered as a party in this, and as such, can represent what he will think convenient in all, and whatever rights belonging to his deceased father; the renunciation of Don Jose M. Hernandez is accepted, and the mentioned James Russell, having sufliciently proved the spoliation of the land which the Treasury Department sold to the deceased, in consideration for the schooner which was bought of him for the service of this place, and of the lands which were granted to him as a new settler, as appears in the proceedings entered into to that effect, and by which this process begins, as appears, also, in the documents he has presented, and the declarations taken of witnesses. First of all, let the possession which he claims be restored to him, with the reserve of the respective right which the actual possessors may consider themselves to hold, in order that they may make use of it, should they think proper so to do; in virtue of which, in order that the restitution may be carried into effect, let Don Francisco Jose Fatio be commissioned for that special act, with all the faculties the law requires, in consideration of the physical impossibility in which the Auditor and only Notary of this Province are of going personally to execute said act of restitution, which impossibility is occasioned not only by the great distance of said lands, but also because said officers cannot for one moment leave this capital, in this critical epoch of the delivery thereof to the Government of the United States-this most important event claiming 
all their attention: let the necessary orders be given to said commissioner, in order that he may, assisted by witnesses, discharge the duties of said commission, of the result of which he will make his report.

COPPINGER. ARREDONDO.

Before me,

$$
\text { - JUAN DE ENTRALgo. }
$$

\section{NOTIFICATION.}

In St. Augustine, on the same month and year, I notified the preceding act to Mr. Janes Russell, which I attest.

\section{ENTRALGO.}

Note. - On the same day, the order aforesaid was issued and delivered to Mr. Francisco Jose Fatio, which I certify.

\section{ENTRALGO.}

\section{PETITION.}

I, James Russell, an inhabitant of this province, in continuation of the proceedings relating to the claim of lands belonging to the estate of my deceased father, and in consequence of the decree issued this day, in which it is ordered that I be put in possession of said land, in the most legal form, I expose to your Excellency, that as the Alderman, Don Francisco Fatio, has been appointed by your Excellency as a Commissioner to carry said decree into execution, I beg your Excellency be pleased in order to make the survey and fix the boundaries of said lands, in conformity to the tenor of the decree, dated 11 th February, 1820, and agreeable to the grant and restitution which is made, to order that Don George Clarke, the Surveyor General, go on the spot to execute the said survey. I, therefore, beg your Excellency be pleased to order, in conformity to my petition-l claim justice.

\section{JAMES H. RUSSELL.}

DECREF.

St. Avgustine, 12 th June, 1821.

Granted, assessor's fees \$S. Let the costs occurred, be regulated and paid.

COPPINGER, ARREDONDO.

Before me,

JUAN DE ENTRALGO.

NOTIFICATION.

In St. Augustine, on the same day, month, and year, I notified the preceding decree to Mr. James Russell, which I certify.

ENTRALGO.

Axother.-On the same day, I notified the same to Don George Clarke, which I certify.

ENTRALGO. 
ORDER.

Don Jose Coppinger, Colonel of the National Armies, Military Governor, Political Chief, and Ultra-marine Sub-delegate of this place and province, \&c. by these presents :

I confer unto Don Francisco Jese Fatio, all the faculties required by law to the effect, that with the two assistant witnesses whom he will appoint, in due form, to assist him in this commision, he trans. port himself on the lands which were by this Government sold to the deceased John Russell, and on those lands which were granted to the same as a new settler; said land situated between the rivers Matanzas and Tomoco, and there put Mr. James Russell, a lawful son and heir of said John Russell, deceased, in possession of said lands, which are hereby restored to him, in consequence of what has been represented and proved in the proceedings relating thereto; with the reserve of the respective rights which the actual occupiers may consider to possess in the lands aforesaid, in order that they may make use of said right if they think proper, and after putting down in writing the result, said Commissioner will make his report, as it is already ordered in my decree of this day, which I issued in conformity to the petition of Mr. James Russell, aforesaid, with the consultation of the Auditor of War.

St. Augustine of Florida, 18th June, 1821.

JOSE COPPINGER.

By order of his Excellency,

JUAN DE ENTRALGO, Notary of Government.

\section{APPOINTMENT OF WITNESSES.}

I, Francisce Jose Fatio, an inhabitant of St. Augustine, of Florida, having repaired to the plantation called the "Good Retreat." in order to carry the preceding order into execution, did appoint, as assistant witnesses. Don'Jose Simeon Sanchez and Don Francisco Pellicer, who accepted the office, and promised under their legal oath, to proceed well and faithfully to the discharge of their duty, and signed-

\section{FRANCISCO PELILER, JOSE SIMEON SANCHEZ, FRANCISCO FATIO.}

\section{REPORT.}

In Tomoco, on the 21st June, 1821. In conformity to the tenor of the preceding order, I Francisco Jose Fatio, accompanied by the witnesses assistants, who subscribed this, and by Mr. James Russell, we went to the place aforesaid, riding about on horseback, and taking said James Russell by the hand, I put him in possession of the lands referred to in my commission, there he called aloud, pulling up the grass, threw up sand in the air, broke branches of trees, and 
did other things indicating possession, which he took quietly and peaceably, and without contradiction; and in proof thereof, I make this report, which I sign together with the witnesses and the interested party.

FRANCISCO PELLICER, FRANCISCO JOSE FATIO, JOSE SIMEON SANCHEZ, JAMES H. RUSSELL.

\section{Decree.}

St. Augustine, 25th June, 1821. ACTs.

Before me,

Two flourishes. JUAN DE ENTRALGO.

\section{NOTIFICATION.}

In St. Augustine, on the same day, month, and year, I notified the preceding decree to Mr. James Russell, which I certify.

ENTRALGO.

ACT.

St. Augustine, 26th June, 1821.

Seen the above-I approve all that the law admits. The proceed. ings of the Constitutional Alderman, Don Francisco Jose Fatio, and in consequence thereof, I declare Mr. James Russell to be in possession of the lands, the restitution of which he has claimed, and in which he will be protected; let the costs latterly incurred be regulated, and let the abovementioned Russell pay the same.

COPPINGER. ARREDONDO.

\section{NOTIFICATION.}

St. Augustine, on the same day, month, and year, I notified the preceding act to Mr. James Russell, which I certify.

ENTRALGO.

PETITION.

To His Exceltency the Governor.

I, James Russell, an inhabitant of this Province, with due respect, represent to your Excellency, that the survey being concluded and the boundaries fixed, of the 4,675 acres of land, which $\mathrm{I}$ have claimed from this tribunal, as being of right the property of my deceased father, whom I, as his heir and executor, represent according to 
the tenor of the proceedings relating to that affair; and as said survey is proved by the two draughts certified and annexed, I hope from the justice of your Excellency, that after admitting the presentations of the same, you will be pleased to order it to be annexed to the act, and registered in the archives of this Government ; and that the present Notary deliver me the certificates of the whole proceedings. I therefore beg your Excellency to order in conformity to my Petition; which favor $I$ expect to receive.

JAMES H. RUSSELL.

Florida, 28th June, 1821.

\section{DECREE.}

St. Augustine, 28th June, 1821.

ACTs.
Before
Two flourishes.
JUAN DE ENTRALGO.

NOTrYication.

In St. Augustine, on the same day, month, and year, I notified the preceding decree to Mr. James Russell, which I certify.

ENTRALGO.

DECREE.

St. Augustine, soth June, 1821.

Seen-granted in every particular.

Before me,

COPPINGER, ARREDONDO.

JUAN DE ENTRALGO.

\section{NOTIPICATION.}

In St. Augustine, on the same day, month, and year, I notified the preceding decree to Mr. James Russell, which I certify.

\section{ENTRALGO.}

This copy is conformable to the originals which remain in the archives under my charge, to which I refer; and in obedience to the superior order issued at the request of the interested party, I seal and sign the present certificate, contained in forty-seven leaves of common paper, as stamped paper is not used here.

JUAN DE ENTRALGO, Notary of Government, \&c.

St. Augustine, July 6, 1821.

Don Gabriel W. Perpall, Don Jose M. Hernandez, and Don WilJiam Travers, Mayor, and Aldermen, Constitutional Members of the Council of this City, certify that Don Juan de Entralgo, by whom the 
preceding certificate appears to be sealed and signed, is the Notary of the Government, and of the Treasury Department, as he styles himself; that he is the only one in that capacity in this place and Province; that he is faithful, legal, and trusty; and that a full faith and credit has always been given to those who have filled the said two offices, and in proof thereof, and at the request of the interested party, we sign the present in St. Augustine, Florida, the 6th of July, 1821.

\section{GABRIEL W. PERPALL, JOSEPH M. HERNANDEZ, WILLIAM TRAVERS.}

Don George Clarke, Lieutenant of the militia of the city of St. Augustine, of Florida, and Surveyor General by the appointment of the Governor of said place and province :

I certify that, in consequence of the superior order issued on the 19th of June, 1821, relating to the proceedings made at the request of Mr. James Russell, claiming 4000 acres of land bargained for with the Governor by his deceased father, I have made the survey and marked the boundaries of 3486 acres of land as part of the said 4000 , in the place called Graham's Swamp, situated between the rivers Matanzas and Tomoco, the particulars of which are conform to the following draught and to the original which remains in my possession.

\section{GEORGE J. F, CLARKE.}

St. Augustine, 25th June 1821.

\section{[Here follows a plat of the survey.]}

Don George Clarke, Lieutenant of the militia of St. Augustine, Florida, and Surveyor General appointed by the Governor of the said place and province :

I certify that, in consequence of the superior order issued on the 19 th June, 1821, relating to the proceedings made at the request of Mr. Jaunes Russell, claiming 4000 acres of land which his deceased father bought of the Governor, I have made the survey and fixed the boundaries of five hundred and fourteen acres, on the West side of the river Kalifax, which, with $\mathbf{3 4 8 6}$ acres already surveyed on Graham's Swamp, make the complement of the 4000 acres aforesaid; which said tract of 514 acres is conform, in all its particulars, to the following draught and the original thereof which remains in my possession.

St. Avguștrine, 25th June, 1821.

GEORGE J. F. CLARKE.

[Here follows a plat of the survey.]

Don George Clarke, Lient. of Militia of St. Augustine, Florida, and Surveyor General, appointed by the Governor of this place and province:

I certify that I have made the survey and fixed the boundaries of 
675 acres of land, in favor of Mr. James Russell, which lands were granted to his deceased father, on the 28th of July, 1812, and which, in every particular, are conform to the following draught, and the original thereof, which remains in my possession.

G. J. F. CLARKE.

St. Avgustine, 25th June, 1821.

[Here follows a plat of survey.]

I certify that the foregoing is a translation from a document in the Spanish langùage.

$$
\text { F. J. FATIO, S. B, L. C. }
$$

Here follows a deed of conveyance from Mary Russell, James H. Russell, William E. Russell, Richard H. Russell, Mary E. A. Russell and Thomas Philson, heirs of John Russell deceased, to claimant, dated 1st August, 1821.

\section{St. John's County, ss.}

This day appeared before the subscriber, a Justice of the Peace, Joseph Delespine, who being duly sworn to give testimony in the above case, doth despose and say that he knew John Russell who had a grant made to him by the Spanish Government for the lands above mentioned, that the said John Russell is dead, that the heirs of the said Russell sold the said land to Charles W. Bulow, that Russell left a widow Mary Russell, daughters Eliza and Mary, sons James, Edward, and Henry; that these persons, so far as this deponent knows and believes, are the only legal heirs of the said John Russell.

\section{JOSEPH DELESPINE.}

Sworn to before me this 24 th day of July, 1824.

$$
\begin{aligned}
& \text { THOMAS H. PENN, } \\
& \text { Mayor of St. Augustine. }
\end{aligned}
$$

DECREE BY THE BOARD.

Charles $\boldsymbol{W}$. Bulow's Ex'rs. ?

The United States. $\}$ do 675 do

The Board ascertain the abore to be valid Spanish grants, and recommended them to Congress for confirmation.

September, 21. 
No. 11 .

\section{$\left.\begin{array}{c}\text { Fernando de la Maza Arredondo, } \\ \text { vs. } \\ \text { The United States. }\end{array}\right\}$ Claim to 15,000 acres of land.}

\section{MEMORIAL.}

To the Honorable the Commissioners appointed to ascertain claims and titles to land in East Florida.

The petitlon of Fernando de la Maza Arredondo, respectfully sheweth, that your memorialist claims title to a tract of land consisting of fifteen thousand acres, situated on the West side of Lake George, in East Florida, bounded and beginning at a palm tree marked $\triangle$ in the margin of Lake George, thence, South $65^{\circ}$ West, 400 chains, to a pine: thence, North $25^{\circ}$ West, 400 chains; thence, North $65^{\circ}$ East, 400 chains, to a palm tree on the banks of said lake; thence, along the meanders of said lake to the beginning. Which tract was surveyed by Andres Burgevin, the 5th August, 1819. Which title your memorialist derives from a royal title made to him, the 9 th of August, 1819, by Governor Coppinger, in virtue of the royal order of 29th March, 1815. A concession of which was made to memorialist the 24 th of March, 1817, as will be seen by a certified copy of royal title herewith submitted. And your memorialist further sheweth, that he is legally in possession of said land, that he is a citizen of Spain, and resident of Cuba. All of which is respectfully submitted.

\section{F. M. ARREDONDO.}

\section{TRANSLATION.}

\section{To the Governor:}

Don Fernando de la Maza Arredondo, inliabitant of St. Augustine, and actually residing in the city of Havana, through his son of the same name, residing in this place, to your Excellency sheweth, that he has the honor of having served his majesty in different employments and destinations, and particularly in the department of Commissary of the Indians, without any salary or any other emolument whatever, for more than twenty years. having discharged the duties of that office with the utmost exactitude to the satisfaction of all the Governors of this place; contributing thereby to the peace and harmony which existed with those savages, with which commission, and that of Controller protem. of the Royal Military Hospital of this town, which he likewise discharged for many years, without any salary or emolument which meritorious services liave saved to the royal revenue many thousand dollars, as is well known to your excellency, and to the public authorities of this place. Latterly after obtaining a discharge from the different employments, he separated himself from the service of his majesty to attend to the discharge of his duty towards his family: he engaged himself in the fatiguing service of patroles, and Aid de Cainp 
to the Governor Estrada, in consequence of the invasion of the province in the year 1812, and for want of officers for that service, in which he was occupied until the year 1813 , when having been elected by a majority of votes, with all the necessary committees on the occasion, elector of the parish and district of this said province, he was obliged to go to the city of Havana, and remain there as one of the Deputies of the Provincial Junta; to discharge the said duty, he was under the necessity, as a loyal subject, to expend large sums, which he actually did, in the service of his King and conntry, being well persuaded that he would be rewarded for it at a future period.

He has been informed, that the royal order of His Majesty of the 29th March, 1815, directs that a memoration of grants of lands be given to all individuals who were armed in the defence of their country, during the insurrection which began in 1812; and as the petitioner is one of them, and is entitled, for this reason, to said gifts, as also, being one of the oldest settlers, and having augmented his family and negroes ever since the cession of this province to His $\mathrm{Ma}$ jesty, and one of those whom the royal ordinances and laws recommend that they may be attended to, both in quality of first settlers; as also on account of his distinguished services, that he be preferred in the partitions of lands. He, therefore, prays your Excellency will be pleased to grant him, in absolute property, 30.000 acres of land; to say, 15,000 acres to the Southwest of the Lagoon, known by the name of lake George, which survey may be so made that a creek of salt water, situated in that place, may occupy the centre of the front thereof, and the remaining 15,000 acres, on the West side of the St. John's river, the measurement of which to commence frem the old Indian Chamchatty Path, opposite the site on which the farm of Panton and Leslie had their store established, known by the name of Upper Store, being at the Sonth side of the Great Lagoon, known by the name of lake George, and thence, in line, to run Southerly; and it completes the number of acres; and, as the actual circumstances of the Province do not perınit, at present, the measurement and chaining of said land, and at the same time as the survey could not take place for want of Surveyors, as Don George Clarke, named by this Government, has other occupations which give him no time to atfend to it, he, therefore, hopes, from the justice of your Excellency, that you will be pleased to suspend the acknowledgment of the titles of the property, whilst the memorialist does not obtain the plats of said lands, in orzier that their situation and limits may be specified with exactness for perfecting the location and situation of the same. In the mean time, the grant which your Lordship may think fit to make him, may serve as a title under your decree, in continuation for it, is the will of the memorialist, that when the sathe be given him, that it may have all requisites necessary - a favor which he hopes to receive from. the justice of your Excellency.

FERNANDO DE LA MAZA ARREDONDO.

St. Augustine, 1st March, 1817. 
St. Augustine, 24th March, 1817.

In attention to the services which this party specifies, which are manifest and notorious, and making use of the power conferred on me by the laws and the royal will, I grant, in the name of His Majesty, and the royal justice which I administer, to Don Fernando de la Maza Arredondo, the senior, the 30,000 acres of land he solicits, in absolute property, in the places he has designated, without prejudice to a third person, of which titles of dominion will be given as soon as the plats, to be made by the Surveyor, be presented; surveying, in the mean time, this decree, and an equivalent in all its parts, which, with the foregoing petition, will be filed in the archives of the Notary of Government and Royal Finance, from whence the interested will be furnished with a certified copy of the proceeding, properly authenticated, and in due form, in order that this concession may be duly credited, and that he may be able to make use of lands, and to dispose of them as he may think proper.

Before me,

\section{COPPINGER.}

$$
\begin{aligned}
& \text { JUAN DE ENTRALGO, } \\
& \text { Notary of Go' } t \text {. }
\end{aligned}
$$

I certify the foregoing to be a true and correct translation from a document in the Spanish language.

$$
\text { F. J. FATIO, S. B. L. C. }
$$

DECREE BY THE BOARD.

In this case we find that the claimant obtained a concession without condition, for 30,000 acres of land, from Governor Coppinger, dated 24th March, 1817, the 15,000 acres being included in said concession, and its location set forth in claimant's memorial to the Buard. In consideration whereof, we recommend the same to Congress for confirmation.

June 5 th, 1824.

Note. For further particulars please to refer to the case of Moses F. Levy, for 14,500 acres, reported to Congress the first session.

No. 12.

$\left.\begin{array}{c}\text { Suan De Entralgo } \\ \text { vs. } \\ \text { The United States. }\end{array}\right\}$ For 4,000 acres of land.

MEMortaI.

To the honorable the Commissioners appointed to ascertain claims and titles to lands in East Florida:

The petition of Juan De Entralgo respectfally sheweth: That youx 
memorialist claims title to a tract of land, consisting of 4,000 acres, situated on Black Creek, and is bounded on the south by Governor's Creek, first line runs South $45^{\circ}$ W. 170 chains, to a pine tree, marked thus $\equiv$ : thence South $45^{\circ}$ E. 250 chains, to a cypress tree, marked thus $\equiv$, which title your memorialist derives from a royal grant made to F. M. Arreclondu by Governor Coppinger, in virtue of the royal order of 29 th March, 1815 , who sold the same to your memorialist ; a copy of the said grant is herewith filed. as is the deed from Arredondo to your memorialist; and your memorialist further sheweth, that he is in actual possession of said lands; that he resided in St. Augustine at the change of flags, and is now in Cuba.

\section{JUAN DE ENTRALGO, by GEORGE MURRAY.}

Translation of a concession for 10,000 acres, part of which is copied in a claim of John De Entralgo, for 4,000 acres, recommended for confirmation.

\section{TRANSLATION.}

Don Andres Burgevin, of this place, and private Surveyor:

II I certify, that by an order of this Government, made the 20th of August, 1819, I have measured in favor of Don Fernandina de la Maza Arredondo, Jun. a piece of land which contains 4,000 acres of land, which is situated to the West of the River St. John, on a creek known in English as Black Creek, being part of a greater quantity which was granted him on the 20th of March, 1814, and for its confirmation I give these presents, which I sign at St, Augustine, Florida, the 25th of July, 1820 .

[The plat precedes this.]

ANDRES BURGEVIN.

I certify the foregoing to be a true and correct translation from a document in the Spanish language, on file in the office of the public archives of St. Augustine.

$$
\text { F. J. FATIO, S. B. L. C. }
$$

TRANSLATION.

\section{Conveyance.}

Be it known, that I, Don Fernando de la Maza Arredondo, Jun. an inhabitant of this city, do declare, that I really sell to Don Juan De Entralgo, Notary of Government and the public domains in this city, four thousand acres of land, which I hold as my property in this province, situated to the West of the River St. John's, on a creek known in English as Black Creek, and having for a boundary another creek named the Governor, known under the following dimensions: The first line runs South $45^{\circ}$ West, measures 170 chains, and ends 
*ith a pine tree marked $\equiv$. Thé secorid rüns soutli $45^{\circ}$ eàst. measures 250 chairis, and ends in a cypress marked =; which 400 acres of tind, with another portion more, this Government granted me in absolute property and dominion, as a reward for services on the 20th of March. 1817, and for which a full title was given me on the 9th of August last, as appears in the archives of the said Notary ; andd I . seli the said 4,000 acres of land under the dimensions and other things which are explained, with all its entrances, outlets, uses, customs, rights, and services, which it has, and belongs to it, free of all incumbrance, at the price of four thousand dolla'rs, which the purchaser has paid me in ready money, which sum $I$ acknowledge as delivered to my will; I rennunce proof, laws of delivery, exception to money not countel, fraud, and every thing else in the case, for which I deliver a formal receipt, in virtue of which I separate myself from the right of property, possession, use, seigniory, and all other rights, real and personal, which I had or held to the said 4;000 acres of land; and I cede, renounce, and transfer them to the said Don Juan De Entralgo, and to whosoever shall represent his right, that, as their own, they may possess, sell, and alienate it at their will, in virtue of this writing, which I give in their favor as a mark of real delivery, by which it is seen that he has acquired possession, without occasion of other proof, from which I release him ; and I bind myself to the eviction and guaranteé of this sale in sufficient form, and as may be best In favor with the purchaser, with my jroperty, present and future, power and subimission to the tribunals of his Majesty, that they may force me to compliance with it, as by senterice confessed and passed in autliörity of an adjudged case, on which I renounce all laws, customs, rightht; and privileges in my favor, and formal exceptions which prohibit it; and I, the said Don Juan De Entralgo, being present, accept in my favor this writing, and by it receive as purchased the said 4,000 acres of land at the price and agreement upon which they were sold to me. and I acknowledge them as delivered to $\mathrm{my}$ will; I renounce proof laws of delivery, those of a thing not seen or received, fraud, and every thing else in the case, for which I deliver a formal receipt. In testimony of which, this is dated at St. Augustine, Florida, the 5th of Jaintary, 1821.

I, Jose Coppinger, Colonel of the national armies, Military Qovernor, Civil Chief, and Sub Delegate of ultra marine possessiơns, for this city and province, do certify that I know the parties who thus said, delivered, and signed in my presencé, and that of assistant witnesses whom I have chosen for this deed, Don Tomas De Aguilar and Don Antonio Alvarez, there being no other Notary in the entire province. The witnesses to this writing being Don Jose Mariano Fernandez, Don Bernardo Segui, and Don Jose Bernardo Reyes. Witnesses present, Coppinger, Fernando M. Arredondo, Juan De Entralgo, Tomas De Aguilar, Antonio Alrarez.

This is conformable to the original which exists in the archives of the said Notary of Gorernment; to which 1 refer; and, at the desire 
of the party, sign this present copy, with the assistant witnesses, on two leaves of common paper, stamped not being in use.

\section{Tomas De Agumar, \\ Antonio Alvakez.}

St. Augustine, Florida, 5th of January, 1821.

I certify the foregoing to be a true and correct translation from a document in the Spanish language, on file in the office of the public archives of St. Augustine.

JOSE COPPINGER.

$$
\text { F. J. FATIO, S. B. L. C. }
$$

\section{Detree.}

Juan De Entralgo,

The United States, $\}$ For 4,000 acres of land.

The Board having ascertained the above to be a valid Spanish concession, made previous to the 24th of January, 1818 , and this claim being part thereof, regularly conveyed to claimant, it is, therefore, recommended to Congress for confirmation.

soth of June, 1824.

No. 19 .

$\left.\begin{array}{c}\text { John Forbes, } \\ \text { vs. } \\ \text { The United States, }\end{array}\right\}$ For 4,000 acres of land.

\section{Memorial.}

To the honorable the commissioners appointed to ascerfain claims and title to land in East Florida. The petition of John Forbes respertfully sheweth, that your memorialist claims title to a tract of land, consisting of seven thousand acres, situated on little St. Mary's, and bounded as follows: first line commencing at a pine tree near Spell's Swamp, running North $10^{\circ}$ West, 246 chains to a pine, thence South $80^{\circ}$ West, 286 chains to a pine, thence South $10^{\circ}$ West, 246 chains to a pine, thence North, $80^{\circ}, 286$ chains, to the beginning, and containing within the said boundaries, 7000 acres, as appears by a survey matie by Geo. J. F. Clarke, and a plat of which is herewith filed, marked B.- which title your memorialist derives from a grant made to himself by Governor Kindelan, on the 28th day of July, 1814See Document marked A. filed herewith; and your memorialist further sheweth, that the said tract of land was surveyed by George J. F. Clarke above named, on the 23d October, 1816, as will appear by the paper marked B. Your memorialist further sheweth, that he is 
in possession of said lands; that at the change of Flags, he was a spanish subject and resident of Cuba.

JOHN FORBES.

\author{
A. \\ [TRAXSLATIOX.]
}

Memoriat.

Senor Governor-I Don Juan Forbes, partner of the house of Juan Forbes \& Co. successors of Panton, Leslie \& Co. merchants of this province, before your Excellency, with due respect, appear and say, That the aforesaid house of Panton, Leslie \& Co. obtained in the year of 1799 , a concession of fifteen thousand acres of royal lands, in the district of St. John's, to employ their negroes in agriculture, and pasture their cattle, as appears by the annexed certificate; but, at the end of a very little time, it was found necessary to abandon them, from their being of an inferior quality, having experienced what commonJy happens in this province, where the farmer does not succeed in his choice, until sad experience; and as it has been seen by many precedents, that the Government, attending to similar misfortunes and the injuries and expenses which have been incurred, has had the goodness to allow that they should select lands belonging to the King, always giving up the former concession. Finding myself in this case, and desirous to establish a plantation of rice, which, up to this time, we fiud ourselves obliged to bring from abroad, I make from now a surrender of the said fifteen thousand acres of land, in favor of his majesty, (whom God preserve) praying that you will be pleased to allow it, and in its place grant me the equivalent in the District of Nassau River, in virtue of which, he prays your Excellency to be pleased to command, that the formal surrender which I make shall be allowed, and that, in consequence. there be granted to me, ten thousand acres in the said District of the River Nassau, the survey of which I shall present as soon as the province becomes tranquil, and gives an opportunity to effect it, which I will receive as a favor, \&c.

JUAN FORBES.

\title{
Decree.
}

Let the report be made from the Comptroller's office.

KINDELAN.

\section{REPORT.}

As in this province, lands are given gratis, the Comptroller's office has not taken cognizance of their distribution, nor to whom, for which reason it is ignorant of the grants, and of the lands remaining vacant, and therefore cannot say any thing respecting the particular, which it is ordered to report. Nevertheless, it appears that the culture of rice crops is useful, for which, according to the statement of the inter- 
ested, the lands are irot fit, which were granted to him on the 7 th of August, 1799, with the expression of for pasture, as the accompanying certificate shews, given by the former Secretary of the Government, Don Juan de Pierra.

St. Augustine, (Florida, ) 27th July, 1814.

MANUEL LOPEZ.

St. Aquguștine, 28th July, 1814 .

Let this interested party be allowed the formal cession which he makes of the fifteen thousand acres of land, which the Document, accompanying this Memorial, comprises, and, in their place, let there be granted him, without injury to a third person, the ten thousand acres for the purposes which he solicits, in the district, on the margin of the river Nassau; and in consequence, let the correspondent certificate be issued to him, from the Secretary's office, that it may serve him for'a title in form, this party having to present the plat and demarcation, at his own time, and the proceeding be placed in the archives of the Secretary's office.

KINDELAN.

On this date, a copy of this proceeding was furnished to the interested; date as above.

\section{AGUILAR.}

I certify the foregoing to be a true and correct translation from a ducument in the Spanish language, on file in the office of the public ârchivas of St. Augustine.

$$
\text { F. J. FATIO, S. B. L. C. }
$$

\section{[TRANSTLATION.]}

Don George Clarke, Lieutenant of Militia of the cify of St. Augustine, Florida, and Surveyor General, appointed by the Governor of said place and Province:

I certify that I have measured and laid off for Don Juan Forbes, seven thousand acres of land; at the head of the little St. Mary's river, on the banks of the river St. Mary's, to complete ten thousand acres, which were granted to him in absolute property, by the Government, and conformation to tbe following plat and its copy, which I preserve in the book of surveys in my charge.

Ferpandina, 23d October, 1816.

GEORGE J. F. CLARKE.

[Here follows the plat.]

I certify the foregoing to be a true and correct translation from a document in the Spanish language.

F. J. FATIO, S. B. L. C. 


\section{$\left.\begin{array}{c}\text { John Forbes, } \\ \text { vs. } \\ \text { The United States. }\end{array}\right\}$ For 7000 acres of Iand.}

The above being a valid Spanish concession, made previous to the 24th of January, 1818, and this claim being part thereof, it is therefore recommended to Congress for confirmation.

July 13th, 1824,

$\left.\begin{array}{c}\text { John Forbes } \\ \text { vs. } \\ \text { The United States. }\end{array}\right\}$ Nor 3,000 acres of lami.

\section{Memorias.}

To the Hon. the Commissioners appointed to ascertain claims and titles to land in East Florida.

The Petition of John Forbes respectfully sheweth, that your memorialist claims title to a tract of land containing 3,000 acres, being a part of a tract of 10,000 acres granted to the said John Forbes, by Governor Kindelan, on the 28th day of July, 1814, in lieu of the quantity of 15,000 acres, abandoned by your memorialist, on the St. John's river. The said 3,000 acres situated in Cabbage Swamp, or near an arm of the little St. Mary's river, and is bounded as follows, as will appear by a survey and plat thereof, made by J. F. Clarke, filed herewith, marked B, and dated the 20th day of October, 1816, viz: beginning at a pine tree and running south $80^{\circ}$ west, 195 chains, to a pine tree south $45^{\circ}$ west, 35 chains to a pine; thence, west, 77 chains, to a pine; thence, north, 105 chains to a pine; thence, north, $80^{\circ}$ east, 299 cliains, to a pine marked oXIII-thence, south, 105 chains to the beginning. Your memorialist further sheweth, that he was a Spanish subject, residing in Cuba, at the change of flags in 1821.

JOHN FORBES.

[Here follows translation of a concession for 10,000 acres, to John Forbes, dated the 28th of July, 1814, copied in a claim for 7,000 acres.]

\section{Trasglation.}

Don George Clarke, Lieutenant of Militia, of the City of St. A4: gustine, Florida, and Surveyor General, appointed by the Government of the said City and Province:

I certify, that I have measured and laid off for Don Juan Forbes, 3, 000 acres of land, in Cabbage Swamp, near the River St. Mary's, in part of 10,000 acres which were granted him by the government, in absolute property, and agreeable to the following plat and its copy, 
which I keep in the Book of Surveys in my charge. Fernandina, 20th October, 1816.

GEORGE J. F. CLARKE.

[Here follows the plat.]

Decree,

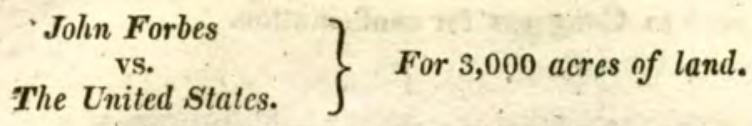

The Board having ascertained the above to be a valid Spanish concession for 10,000 acres, made previous to the 24th of January, 1818, do therefore recommend it to Congress for confirmation.

July 13 th, 1824.

No. 21.

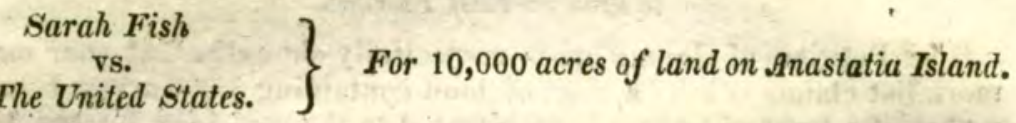

\section{MEMORIAL.}

To the honorable the Board of Commissioners appointed by Congress to try the validity of titles to lands in Fast Florida, the memorial of the subscriber respectfully sheweth :

1. That your memorialist claims title to the island lying in the front (i. e. to the east) of the city of St. Augustine, and running south about 18 miles, more or less, along the east bank of the River $\mathbf{M a -}$ tanzas. known by the name of the Island of St. Anasthatia, supposed to contain ten thousand acres, as belonging to her deceased husband, Jose Fish, Sen. in the year 1763.

2. That in the year 1792 , this island was sold at public sale by order of the Spanish Governor Quesada, when her son, the late Jose Fish, Jun. deceased, became the purchaser.

3. That the Spanish Governor Quesada, or his deputy, Morales, (from the indisposition of Governor Quesada, ) with the advice of the King's Attorney, Ortega, did then reserve a certain part of the quarry existing on said island, which reservation was made for the stake of the stone, only for the purpose of keeping in repair the King's fortification and other public buildings. The part so reserved has alwayg been known by the name of the King's quarry, and begins at what is called the King's road to the south, and as far as a small distance to the north of the light house, east and west no farther than where the quarry ends, as appears by stakes (if not taken away). which were planted at the delivery.

All the above explanations will appear by the annexed vouchers, 
delivery of said island with witness, (as a Spanish custom,) and receipt from the Treasurer for the money.

St. Augustine, s1st August, 1823.

SARAH FISH.

TRANStATION.

Florida, 1794.

Don Jose Fish, soliciting from the Governor that the ten thousand acres of land should be granted to him which his deceased father of the same name possessed at the plantation named the Orange Grove, which was sold at public auction.

Senor Govertiot and Commander in Chief:

Don Jose Fish, native and resident of this city, presents himself before your Excellency with the most profound respect; states that, at the public auction which was made of the property of his deceased father, for the payment of his creditors, the memorialist purchased the place called the Orange Grove, at $\$ 1,700$, which sum he only gave with a view to the fruit trees of said place, and the wood which is on the land belonging to it, as the lands are entirely useless for plantirrg; that he las observed that several residents are cutting the said wood, and therefore he humbly prays your Excellency to be pleased to declare him owner of the lands which his said father possessed, annexed to said place of the "Orange Grove," which, according to the deeds granted in the time of the British possession, amounted to 10,000 acres, according to what Don John Lutil and Don Manuel Solano can declare, it being well known to them, from their having been here at that time, whether it may be as a new settler of this province, or by the right which his deceased father had to them, since, if your memorialist does not obtain this favor from your Excellency, he will consider himself as at the loss of the greatest part of his purchase, because the lands will not produce crops of any kind, and a great number of the fruit are dried, which is likely to recur to the remainder of them. A favor which he does not doubt to enjoy from the justice of your Excellency.

JOSE FISH.

St. Augustine, Florida, 2d of Dec. 1796.

Let his Honor the Assessor General consult with me. Thus it is decreed and ordered, by Senor Don Juan Nepomuceno de Quesada, Brigadier of the Infantry of the Royal Armies, Governor Command. er in Chief, vice Regal Patron and Sub-delegate of the Royal Domain of this city of St. Augustine, Florida, and its Province for his Majesty, who signed it on the 15 th December, 1794, which I attest.

QUESADA.

Before me,

JOSE DE ZULEZARRETA, Notary of Government.

On the same day this was made known to Don Jose Fish, which $\mathbf{I}$ attest.

ZULEZARRETA, Notary. 
I have seen this memorial of Don Jose Fish, and if it directed itself to the setting forth that lie would prevent other persons from cutting wood on his lands, or to recover them, according to the titles of his property, and the injuries which it has caused, or might have caused him, I would consult on the interlocutory decree with your Excellency, according to law; but this memorial ending in making out for Fish the boundaries of the lands which his father possessed at the time of the British dominion, which he desires should be granted to him to the same number of acres, which he sets forth as annexed to the Orange Grove, which he purchased at public auction. held of the property left by the decease of his said fatirer, the said sale as the present Notary states, and setting forth the boundaries of those which this party purchased, when he did the Orange Grove : It remains with your Excellency to assign him those which he asks for, as a new settler, to which the possession of his father, alleged by him, gives him some right of preference, and the more if he prove it; or to distribute to him those which yoar Excellency thinks proper, and which may be withotat injury to another possessor, with which hearing in the case, it ought to be determined judicially. This is my opinion, which I sign' in' St. Augustine, Florida, 15th Dec. 1794.

\section{JOSEF DE ORTEGA, Licentiate.}

\section{St. Augustine, Florida, 15 th D̈ec. 1794.}

In confortaity with the foregoing opinion, lett the interested make the proof which he announcess before the present Notary, to whom it is committed, and on sight of it, the matter on which it treats shall be deciled upon, for which purpose let the proceedings be brought forward.

Before me;

JOSE DE ZULEZARRETA, Notary of Governient.

On the same day, month and year, the foregoing decree was made knowin to Don Jose Fish, which I certify.

\section{ZULEZARRETA, Notary.}

In the city of St. Augustine, Florida, the 22d of September, 1795, brfore me, the Notary, Don Jose Fish presented as a witness, for the proof which he was ordered to give, Don Johm Leslie, resident and merchant of this said city, from whom, in conformity with the commission which was conferred upon me, I received the oath which he made in all form of law, under which he promised to tell the truth to the best of his knowledge, in what should be asked him : and it being done so; in consequence of the aforesaid petition presented by the said Fish. That as the person who declares was one of those, who, in the time of the British Government, valued the lands, houses, and Jots, which Don Jose Fish, deceased, had in this Province, and amongst them was the plantation named the Orange Grove, which his son, of the same name, now claims, which he possessed with lawful titles, given in the time of the former Spanish Governor; and is 
is known to him that he had the 10,000 acres of land, a little more or less, according to the knowledge and belief of the deponent, in possession, of which he remained peaceably, while the British Government held this Province; and answers, that, what he has said is the truth, by virtue of the oath which he has taken; that he is over 25 years of age, and signed this, which I attest,

Before me, JOHN LESLIE. JOSE DE ZULIZARRETTA, Notary of Government.

In the city of St. Augustine, Florida, the 10th of February, 1795, the said Don Jose Fish presented as a witness Don Lorenzo Llanes, resident of this city and a native of it. from whom, I, the Notary, received the oath which he made by God and the holy cross, according to law, under which he promised to say the truth in what he knew and should be asked of him; and it being done so, in consequence of the foregoing petition he said, that as a native, which he is, of this city, and having lived in it both during the time of the old Spaniards, as well as the greater part of that in which this Province was governed by the British arms, he is certain of having always seen the deceased Don Jose Fish, the father of the memorialist, in possession of the Orange Grove, which, a little more or less, contains the 10,000 acres of land which is stated, which it is also weh known to him he possessed, with lawful titles from the old Spanish government; and he answers, that this is the truth under his oath; that he is of the age of 45 years, and signed this, which $I$ attest,

Before me, LORENZO LLANES. JOSE DE ZULIZARRETTA, Notary of Government.

In the city of St. Augustine, Florida, on the same day, month, and year, he presented as a wituess Don Manuel Solana, native and resident of this city, from whom I, the Notary, received the oath, which he made by God and the Holy Cross, according to law, under which he promised to tell the truth, to the best of his knowledge, in what should be asked him; and being so, as to the tenor of what the foregoing petition, presented by Don Jose Fish, contained, said that, as a native and resident of this said city, in which he has always resided, he is certain that Don Jose Fish, the person who brings him forward, has possessed, in the island called St. Anastatia, the plantation called the Orange Grove, in which he lived, since the time of the old Spaniards until they returned to take possession of this province, in the year 1784, and since that, until '90 or' 91 , when he died, and was buried in the same plantation; and from what the deponent has heard of the survey and valuation, which was generally made hefore the English had delivered this province to the Spaniards, of the real property of the said Fish, he knows that, at the said plantation, he possessed the 10,000 acres of land; and the deponent corroborates it, a little more or less, from what he has seen on the many occasions when he was at 
the said plantation; and he answers that this is the truth, by virtue of his oath; that he is of the age of forty-six years, and he adds that he recollects, that. at the time of the old Spaniards, the deponent went with the Notary, Don Jose de Leon, by command of the Government, to separate the King's Quarries, on the said island, in order to grant the remainder of it to Don Jose Fish, who solicited it, as it was actually granted to him after having made said separation. That after the Spaniards returned to take possession of this province by the treaty of peace with the English, who ruled it about twenty years, and the second year of possession, the Government commissioned him, that, with the Engineer Don Manuel de la Roque and two other workmen, they should designate the old quarries, which they actually did; and they set up four stakes to mark out the lands of the king on the said island, and Fish remained owner of the remainder, as he had seen until then. He did not sign it, as he said he could not write; which I attest.

Before me,

JOSE DE ZULIZARRETTA, Notary of Government.

\section{St. Augustine, Florida, 12th February, 1795.}

The foregoing proof being completed, and in order to the making a decree more fully, let the whole be submitted to the Collector of the Royal Treasury, that, as fiscal of it, he may represent as convenient in the discharge of his functions, and with what he may say let it be brought forward.

Before me,

JOSE DE ZULIZARRETTA,

QUESADA. Notury of Government.

On the same day the foregoing decree was notified to Don Jose Fish; which I atlest. ZULIZARRETTA, Notary.

On the same date it was communicated to Senor Don Gonzalo Zamorano, Collector of the royal treasury, as Fiscal of it. Which I attest.

ZULIZARRETTA, Notary.

The Collector of the Army and of the Royal Domain, as Fiscal of it, in the proceedings moved by Don Jose Fish, on which he was declared owner of the lands which his father possessed, annexed to the situation called the Orange Grove, which he bought at auction, and according to the decree of your Excellency, of the 12th of the present month, in which your Excellency/was pleased to order that they should be submitted to him, states, that, at the sale which was made of the said place of the Orange Grove, to Don Joseph Fish, son of the deceased of the same name, the boundaries of the land were not taken into consideration, and only the valuation of the trees within the precincts of the said Grove, without noticing the 10,000 acres of land annexed to it, according to the report of the Notary of Government and the Royal Domain; the Fiscal Minister is of opinion that, although Fish proves, by the proofs he has given in, that his father pos8 essed in the time of the British and Spanish Governments, all that 
land, he ought to have a right to nothing more than what he proves by the inventory, valuation, and sale, which was made of the said Orange Grove. That this land being laid off, the remainder, up to the 10,000 acres of land, ought to be sold as belonging to his deceased father, and for the benefit of the creditors of his estate, said Fish getting the preference for as much as another would give. That, for the better proof and elucidation of this proceeding, it seems fit to the Minister, that your Excellency should be pleased to order that there be annexed to the testimony the inventory, valuation, and sale, of the said Orange Grove, which was sold by auction to Fish, at the sum of 81605; and in case that Don Joseph Fish has occasion for public lands, without injury to a third person, the Fiscal Minister does not find any objection that your Excellency should grant them to him as a new settler, according to what $\mathrm{His}$ Majesty has commanded in this particular, which is all that offers itself to me for your Excellency's consideration, who will please to determine as appears most just.

\section{St. Augustine, Florida, 27th Feb. 1795.}

GONZALO ZAMORANO.

Let the testimonial, which is indicated, be placed in continuation, and with it these proceedings returned to the Assessor General, that he may consult with me as to what is proper as respects the other points to which the foregoing fiscal representation refers. It is thus decreed and ordered by Senor Don Juan Nepomuceno de Quesada, Brigadier of Infantry of the Royal Armies, Governor, Commander in chief, Vice Regal Patron, Sub-delegate of the Royal Domain of this city of St. Augustine, Florida, and its province, for $\mathbf{H}$. M. which he signed on the 6th of March, 1795, which I attest.

QUESADA.

Before me,

JOSE DE ZULIZARRETTA, Notary of Gov't.

On the same day the foregoing decree was made known to Don Jose Fish, which I attest.

ZULIZARRETTA, Notary.

On the same day it was made known to Don Gonzalo Zamorano, Collector of the royal revenue, as Fiscal of the same, which I attest. ZULIZARRETTA, rotary.

\section{Commission.}

Don Juan Nepomuceno de Quesada, Colonel of the Royal Armies, Governor and Commander in chief of this city of St. Augustine, Florida, and its province, for H. M.-Whereas, in the proceedings which took place in this tribunal, arising from the recovery of the estate which remained by the decease of Don Jose Fish, resident, that was of this city, for the payment of his debts, on which the proceedings be- 
ing opened, several creditors appeared, on the memorial of the de= fender, appointed for said estate. Don Fernando Arredondo, I have grunted permission that there should be valued and sold, at public auction, the lands which result in the said proceedings, to be the property of Fish, to avoid the deterioration some of them were about to experience, and which would ultimately result to the injury of the creditors, and, according to what was resolved in the decree of the 15th of December last, with the houses and lots of the same; wherefore, according to what has been decreed by me, under date of the 16 th instant, 1 have appointed, and do appoint, as said valuators, men skilled in such business, Don Manuel Solano and Don Roque Leonardy, the former a Justice of the Peace, and the latter Ensign of the local militia of it; that, taking into consideration the boundaries, and whatever else appears in said proceedings, wolich extract will be pleased, in continuation and in the presence of the said defender of the estate of Don Vincent Mexias, Don Fran. Rivera, as witnesses present, commissioned by the Government for the want of a Notary, let them pass to said places with proper justice and integrity, for which purpose let the said valuators previously appear before this Government. and then proceed to begin the commission in the following form: 9 th item. The place called the Orange Grove, which belongs to the deceased, although the title under which he enjoyed it, does not appear in the proceedings; and when concluded let it be returned with their account of what has been done, to this Go. vernment; to proceed further as they may think proper.

St. Augustine, 18th January, 1792.

\section{Valuation.}

Valuation and survey of the savannas, lands, and lots, belonging to the estate of the deceased, Don Jose Fish, made by the appraisers appointed, Don Manuel Solano and Don Roque Leonardy, in virtue of a commission by His Excellency the Governor and Commander in chief of this city and province, for his H. M., in presence of $D$. Vincente Mexias and Don Fran. Rivera, for want of a Notary, and the assistance of the defender, Don Fernando de la Maza Arredondo. 6 th item. The Orange Grove consists of 540 large orange trees which are of the best quality, and valued at three dollars, which amount to 1620 hard dollars; and said property answers to No. 9 of the commissioners,

Idem 300 small ones, bearing fruit, at 4 reals, 150 hard

$$
\text { dollars - } 15000
$$

Idem 250 orange trees to transplant, at 3 reals, 33 dollars 6 reals - - - - 9306

Idem 400 sour orange trees, at 4 reals, 200 hard dolls. $\quad 20000$

Idem 120 medlar trees, at 4 reals, 60 hard dollars $\quad-\quad 6000$

Idem 75 fig trees, at 2 reals, 18 dollars 6 reals $-\quad-\quad 1806$

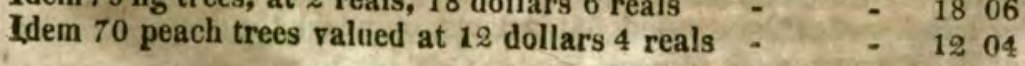


Idem 80 pomegranates, at 2 reals, 20 hard dollars Idem a plantation of lime trees, valued at

Which valuations the said appraisers appointed, declared that they had performed well and faithfully, to the best of their opinions. The first did not sign it because he said he did not know how to write; the second did it with the assistant witnesses and the defender.

\section{VINCENTE MEXIAS, ROQUE LEONARDY, FERNANDO DE LA MAZA ARREDONDO, FRANCISCO RIVERA.}

\section{AUCTION. \\ In the city of St. Angustine, Florida, S1st January, 1792.}

I, the Governor, with the assistance of the Collector of the royal revenue, and defender of the estate of the deceased British subject Don Jose Fish. and the assistant witnesses, by whom it was despatched for want of a Notary, according to what is provided in the decree of said month and year, for the auction and sale of said estate which remained to be sold, at the sound of a drum and by the voice of the frunego, Francisco Blasco, who performed the duty of a crier, having called together a sufficient portion of the people, he began, in a loud and distinct voice, to declare the sale to the best bidder from eleven in the morning of the said day, stating that it was to be sold without reserve, and several bids and out bids having been made by the meeting, and called for by the crier, without more having been offered, which being finished, the auction, the hour having arrived which was pointed out, was concluded in favor of the individuals, and for the prices, which follow:

To Don Jose Fish the orange grove was bid off, which answers to No. 9 of the commission, for the sum of 1605 bard dollars, and there being no person who would offer a larger sum than the foregoing, the hour pointed out being finished, it was ordered that they should be bid off in favor of the aforesaid, interposing the:ein my authority and judicial decree, as I can, and of right ought to do, in virtue of which he was declared the purchaser, and there signed with the Collector of the royal domain and defender of the estate, and the assistant witnesses, for want of a Notary.

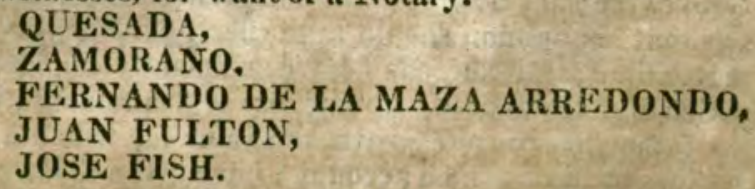

This is conformable to the commission, 9th clause of it, 6th of the valuation, and that of the auction which originated from the proceedings of the meetings of creditors, caused by the death of the English- 
man Don Jose Fish, which remain in the archives in my charge, to which I refer, and in obedience to orders I have caused the present copy, which I sign and seal in St. Augustine, Florida, the 12th March, 1795 .

\section{JOSE DE ZULIZARRETTA,} Notary of Gov't.

Having been seen it was passed over to Don Jose Fish, and was thus ordered and decreed by Senor Don Juan Nepomuceno de Quesada, Brigadier of the Infantry of the royal armies, Governor, vice regal patron and Sub-delegate of the royal domain of this city of St. Augustine, Florida, and its province, for His Majesty, who signed it with the opinion of his honor the Assessor General, on the 26th of March, 1795. Which I attest.

QUESADA. LICENT. ORTEGA.

Before me,

JOSE DE ZULIZARRETTA, Notary of Gov't.

On the same day, month, and year, the foregoing decree was notified to Don Jose Fish. Which $I$ attest.

ZULIZARRETTA, Notary.

On the same day it was communicated to Senor Don Gonzalo Zamorano, Collector of the royal revenue. Which $I$ attest.

ZULIZARRETTA, Notary.

Don Jose Fish, a new settler in this province, and a subject of His Majesty, in consequence of the proceedings which I am following up, in order to have granted to me the 10,000 acres of land which my deceased father, of the same name, possessed at the place named the Orange Grove, which was sold at the public auction which was beld of all his property left at his decease, before your Excellency, in the manner most conformable with law, through the medium of the Public Eolicitor, appear and say, that said proceedings shall be delivered to me to answer the copy which was given me of the representation of the Fiscal, informed of the contents of which I, also, of the subsequent preceedings of the valuation and auction of the said Orange Grove, the said Senor Fiscal not giving a solid and convincing reason that his opinion should take effect, contrary to my right and just pretension; and whereas I have sufficiently confirmed it by the proof which I have adduced, proving, by it the amount of possession which my father had of said Grove, the same for which $I$ have always been anxious, and on which account $I$ have given the excessive price which the proceedings at auction, copied in the judicial proceedings, show ; which sum I would, on no account, have given for the trees alone, which have been valued much less for the lands which these occupy, 
in virtue of which, and submitting to the consideration of your Excellency, that $I$ have not enjoyed the least valuable article of the many which my said father left, as even by the possession to which $I$ aspire I injure my interest, giving more for it than it lawfully is worth, solely impelled by the great love $I$ have for that place, in which I have not only been born, but also brought up and educated, the ancient residence of my dear parents, and beloved sister's who are actually under my protection and charge, without any other help to protect them, which I also do for my dear mother, although with my limited meais, which can only be obtained from the few trees which have been sold at auction, and to which space the Fiscal only pretends to restrict me; wherefore, and hoping that whatever else may be said in my favor will be taken into consideration, as I cannot express myself properly from the little knowledge $I$ have in these matters, and for want of directors in them, I ask and pray your Excellency to be pleased to grant me the said islands, as I have solicited, which favor I hope for from the justice of your Excellency, swearing that I do not proceed from malice, and what is necessary, \&c. Furthermore, to prove the little value and estimation which the place I claim and bought, had, and also my intentions, and that $I$ had given such a large sum, not alone for the trees, but for the land which $I$ have solicited, I pray your Excellency to be pleased to order that the present Notary place in continuation a copy of the deed which he presented, asking for the island, for a valuation, which are united to the principal proceedings of the meeting of the creditors of the estate of my deceased father, and that he may so certify at foot; as, although before it was brought to public sale and auction, there was nothing offered, that all may produce the corresponding effects. I demand justice as above.

\section{JOSE FISII,}

BARTOLOME DE CASTRO Y FERRER.

The copy which is solicited in the note, being placed in continuation, let the whole be passed over to the fiscal representation. It is thus decreed and ordered by Senor Don Jose de Ortega, Advocate of the Royal Council, Lieutenant Governor, Auditor of War, and Assessor General of this city of St. Augustine, Florida, and its province, for H. M., who signed it in consequence of the illness of the Governor and Commander in chief, the 17 th of April, 1795. Which I attest,

LICENT. ORTEGA.

Before me,

JOSE DE ZULIZARRETTA, Notary of Gov't.

On the same day the foregoing decree was made known to Don Jose Fish. Which I attest,

ZULIZARRETTA, Notary. 
On the same day it was communicated to Senor Don Gonzala Zamorana. Collector of the royal revenue, and Attorney of the same. Which I attest,

\section{ZULIZARRETTA, Notary.}

\section{Representation.}

Senor Governor and Commander in chief: Don Jose Fish, with the greatest respect, states to your Excellency. that, at the auction which was yesterday made of the property of my deceased father, there was no person who would bid for the island of the Orange Grove, and that being the place which his father inhabited during his life, the possession of it would be the greatest satisfaction to your memorialist, obliging himself to deliver for it \$1,605 in Government bills, in consideration of which, and said island being abandoned, losing much of its value every day, he prays your Excellency to have the goodness to order that he be placed in possession of it, a favor which he hopes for from the benevolence of your Excellency.

\section{Florida, 22d March, 1792.}

JOSE FISH.

This is conformable to the original which is in folio 135 of the proceedings of the meeting of the creditors of the deceased Don Jose Fish, to which I refer, certifying, as I do certify, that, at the auction which was made on the S1st March, 1792, which runs to leaves 129 of the said proceedings, it does not appear that the Orange Grove was brought forward to public out-cry and auction; but from the various memorials which were presented since said auction, soliciting the purchase of some lands, and the plea of the defender of the estate of the said Fish, which runs up to leaves 142, it is evident that said lands and the Orange Grove had no bidder at that sale at auction; and, in conformity with orders, I sign and seal these presents in St. Augustine, Florida, the Soth of April, 1795.

JOSE DE ZULIZARRETTA, Notary of Goo't.

The first officer of the Chief Comptroller's Department of the army, who performs the duties thereof from the occupation of the Collector, who is charged with the administration and judicature of the royal revenue, from the illness of his Excellency the Governor, and as Attorney Fiscal of the royal revenue. in proceedings moved by Don Jose Fish, in order that he should be declared owner of the lands which his father, of the same name, possessed. annexed to the situation called tie Orange Grove, which was sold at auction, and in consequence of the preceding decree of the 17 th of the month before, in which orders were given that he should examine them, states that, by the copy annexed to this proceeding, it is proved that Don Manuel Solano and Don Roque Leonardy were named as appraisers; that, taking into consideration the boundaries which appear in the testa- 
mentary proceedings of the deceased Don Jose Fish, that possession which belonged to him, was valued in presence of the defender of the estate, Don Fernando de La Maza Arredondo, of Don Vincente Mexias and Don Francisco Rivera, as assistantwitnesses, for want of a Notary; that, in consequence of this, the said appraisers proceeded only to the valuation of the trees of the said Orange Grove, which amounted to $\$ 2,180$, without ascertaining boundaries, nor the number of ac es of land which these valued trees occupy, much less made mention of 10,000 acres of land as belonging to the estate of the deceased Don Jose Fish ; but what does not admit of doubt, is, that, in virtue of that valuation of trees, the sale of them at auction was proceeded to, and was made to Don Jose Fish, son of the deceased of the same name, for the sum of $\$ 1,605$, a little more than two-thirds of said valuation; and consequently, the reason of the Fiscal Attorney, in his opinion of the 27 th of February last. is well founded, in considering Don Jose Fish as owner unly of the land and trees which the said valuation occupy, which is what was lawfully sold at auction'; because until then nothing appeared of the number of acres of which the said Orange Grove consisted-a defect, in truth, very easy to be remedied by the appraisers, since it having been premised to them, that they should lay off the land, they should have done it, with the particular designation of the land which properly belonged to the deceased Fish, from which defect this new appeal arises. Under these circumstances, the Fiscal Attorney thinks that, in virtue of the proof which Fish has made in these proceedings, he proves that the land or site named the Orange Grove, consisted of 10,000 acres of land, and that his intention was, when he bought it, without doubt, under the impression that the 10,000 acres of land which his said father enjoyed, would be included in said sale, because, separating the land occupied by the fruit trees which were valued, the remainder is not fit for planting; and as respects the defect or negligence of the appraisers, Don Manuel Solano and Don Roque Leonardy, in laying off the boundaries of said land, he considers that it ought not to prejudice the right which favors Don Jose Fish. From all these reflec. tions, to which this proceeding gives rise, the Fiscal Attorney concludes, and it appears to him, that your Excellency may order that the boundaries be marked, which correspond to the Orange Grove, to the number of 10,000 acres, of land which he proved belonged to his father, and are annexed to the said Orange Grove, or your Excellency will determine what you may think most proper, with your usual justice.

\section{JOSE ANTONIO DE Y GUINES.}

\section{St. Augustine, Florida, 4th of May, 1795.}

Having examined the proceedings, it was thus decreed and ordered by Senor Don Bartolome Morales, Colonel of the Infantry of the royal armies, Commandant of the third battalion of Cuba, which garrisons this city of St. Augustine, Florida, and Political and Military 12 
Governor of it and its province, from the indisposition of the Grovernor, who signed it on the 16th of May. 1795. Which I attest.

MORALES,

LICENTIATE ORTEGA.

Before me, JOSE DE ZULIZARRETTA, Notary of Gov't.

On the same day the foregoing decree was made known to Don Antonio de y Guinez, for his official cognizance, which $I$ attest. ZULLIZARRETTA, Notary.

On the same day it was notified to Don Jose Fish; which I attest. ZULIZARRETTA, Notary.

St. Augustine, Florida, 13 th of June, 1795.

To decree more fully, let notice be given to the defender of the estate of Don Jose Fish, and have the prnreedings returned.

MORALES.

LICENTIATE ORTEGA.

Before me,

JOSE DE ZULIZARRETTA, Notary of Govt.

Don Rafael Saavedra de Espinosa, attoruey general of this city, and defender of the estate of the deceased Don Jose Fish, who was a resident of this city, and in consequence of the proceedings commenced by Don Josef Fish. son of the aforesaid deceased, appear before your excellency, and in the manner most conformable to law, state, that I have examined, with all the attention my little capacity allows me, what the son of the said Fish sets forth in favor of his right; and I find that up to this time he proceeded inadvertently to the time when he purchased the place called the Orange Grove, at auction, since be ought, at that time, to have shown clearly and distinctly to what his petition referred; notwithstanding which, he now endeavors to remedy his inadvertency by the proof which he has adduced in said proceeding. For all which reasons, and agreeing with the well-founded exposition of the first officer of the royal comptroller's office, Don Jose Anto. de y Guinez, who performs the functions of his honor the fiscal attorney, which exposition is in F 47, in which reference is made to the want of precaution with which the appraisers. Don Manuel Solano and Don Roque Leonardy, proceeded, who ought to have shewn, at that time, the boundaries which that land had, by adverting to which they would not only have given full effect to their commission. but also obviated the present litigation; and, consequently, it wonld have operated with entire effect in the present case, and without waiting for the injury done both the estate and the mover of these proceedings, for which reasons, (it appears to me, ) that your excellenoy may grant to Don Jose Fish the 10,000 acres 
of land which his deceased father, of the same name, possessed: and especially your excellency will decree according to what is every day exhibited in your judicious decrees. This being all $I$ have to say, as defender of said estate, in compliance with the discharge of my duty. RAFAEL SAAVEDRA DE ESPINOSA.

St. Augustine, Florida, 17 th June, 1825.

Having examined those proceedings, and seen the proof adduced in them by Don Jose Fish, it appear's, not only that his father, of the same name. possessed, since the time of the old Spaniards, and in that of the British dominion, the 10,000 acres of land, possession of which he claims at the place called the Orange Grove, which he purchased at public auction, but also that he made a bid for the said land, under which his purchase ought to be understood, which defect, in not explaining it thus at that time, should not be prejudicial to him, and has given cause to this litigation, his excellency said, that, declaring it as he declared now, he ordered, in consequence, that, whether by the right which the burthensome acquisition of the said land gives Fish, which cost bim 1605 dollars. which it appears he paid for the purchase of the Orange Grove, or by the right which the ancient possession of his father gives him to the said 10,000 acres of land : or, finally, in consequence of the petition of Fish that they should be granted to him as a new settler, he be placed in possession of the said land, which it appears his said father possessed, and is already laid off, with the reserve of the quarries, and the remainder which was not granted to his said father, and which the King has reserved : renewing, in case of necessity, at the cost of the interested, the boundaries by the said appraiser. Don Manuel Solano, who, at the time of the old Spaniards, and at the new possession by them of the province, laid off, by order of the government, the aforesaid quarries, to give possession as is proven, to the father of the memorialist, of the land which he claims, and let them be granted to him on the terms above set forth ; the present notary, who is commissioned for the purpose, when with the said appraiser, and any other workman that may be necessary, he shall assist at making the boundary, at which also shall assist, to represent the royal treasury, the person whom the minister of the royal domain may depute for the purpose. All of which shall be made appear on the proceedings, with which, and the taxation of the costs, which the interested shall satisfy, this proceeding shall be held as concluded. It was thus decreed and ordered by Sen. Don Bartolome Morales, colonel of infantry of the royal armies, commandant of the third battalion of Cuba, which garrisons this city of St. Augustine, Florida, and political and military governor pro ten. of it and its province, from the illness of the governor, who signed this, with the opinion of his honor the assessor general, on the 19 th of June, 1795.

Which $I$ attest,

BARTOLOME MORALES, LICENTIATE JOSEF DE ORTEGA. 
In St. Augustine, on the same day, month, and year, the foregoing decree was notified to Don Jose Fish : which I attest.

ZULIZARRETTA, Notary.

On the same day it was intimated to Don Rafael Saavedra de Espinosa, for his coguizance.

ZULIZARRETTA, Notury.

On the same day, month, and year, it was communicated to the Collector of the Royal Domain for his fiscal cognizance.

ZULIZARRETTA, Notary.

Proof of Boundary and Possession.

Being at the plantation called the Orange Grove, on the island of St. Anastasia, on the 10th of July, 1795, in conformity with what is provided in the foregoing decree, we proceeded to the marking of the boundary of the land comprised in these proceedings, Don Manuel Solano, the appraiser appointed for the purpose, passing from said place, to where the quarries of the King and of individuals are situated, who, passing along the ancient boundaries with Don Jose Lorente, Chief Master of the Royal Works, who accompanied him to inform himseif, Don Fadeo Arrebas, Officer of the Royal Comptroller's Office, from the employment of the Collector for his fiscal cognizance, and 1 , the present Notary, went, fixing up stakes, to point out said boundaries, across the island, and separated the said quarries; saying that all beside them was what corresponded to Don Jose Fish, to whom, being also present, I, the said Notary, in discharge of the commission which was conferred upon me, put him in possession of the land pointed out, leading him into it by the hand, and riding together on horseback, by various places. until arriving at the dwelling house; all of which $I$ did as a token of said possession, which he took quietly, peaceably, and without contradiction. In testimony of which, and for the due proof $I$ have extended the present proceedings, which all signed, with the exception of Solano, who said he did not know how ; and all of which $I$ attest.

FADEO DE ARRIBAS, JOSE FISH. JOSE LORENTE.

Before me,

\section{JOSE DE ZULIZARRETTA,} Notary of Government.

I, Francis J. Fatio, Secretary of the Board of Land Commissioners for East Florida, do hereby certify, that the foregoing is a true and correct translation, from a document in the Spanish language, on file in the oflice of the public archives.

F. J. FATIO, S. B. L. C: 


\section{Transtation.}

Having seen that, of the justification set forth in these proceedings, by Don Joseph Fish, it not only appears that his father, of the same name, possessed, since the time of the Old Spaniards, and during the British dominion, the 10,000 acres of land, which possession he claims at a place called Vergel, which he purchased at public auction, but also he fixed a price to the said land, according to w hich the sale ought to have taken place, which defect, in not making it known at the time of the same, ought not to injure him, and which has given cause to this litigation; his Excellency said, that declaring it. as by these presents he does declare. and ordering, in consequence, by the right which the honorable acquisition of the said land purchased, in the sum of 1605 dollar's gives to Fish, as is proven by the sale, which he paid for the Vergel, or by the right given him by tire oid posession of his father, of the above mentioned 10,000 acres of land; or, lastly, in consequence of the petition of Fish, that it should be granted to him as a new settler, he is put in possession of the same land which is known his father possessed, and is already laid off, with the exception of the quarries, and. also, what was not granted to his said father, and was also reserved by the King; renewing, if thought necessary, at the expense of the interested, the boundaries, by the same skilful person, Don Manuel Solano, who, at the time of the old Spaniards, and their possession of these Provinces laid, off, by order of the Government, the aforementioned quarries, to give possession, as was effected by the fatlier of the memorialist, of said land; and he is granted on the same terms, as above set forth, giving him possesion thereof by the present Notary, who is commissioned for that purpose, whenever the skilful person named, and some other person that may be named, for the purpose of laying off the same, and, also, the Minister of the Royal Finance, who will attend as Representative of the Royal Exchequer, all of which will be made to appear in the returns, and which the valuation of the cust, which the interested will pay, these proceedings will be considered at an end ; being thus decreed and ordained by his Excellency. Don Bartoleme vorales, Col. of Infantry of the Royal Armies, Commandant of the $3 \mathbf{d}$ Battalion of Cuba, which garrisons this City of St. Augustine, Florida, and Civil and Military Guvernor, pro tem. of the same, and its Province, on account of the indisposisition of the incumbent; signing it with the advice of the Attorney General, the 19 th of June, 1795.

\section{I attest, \\ BARTOLOME MORALES, LICENTIATE JOSE DE OR'TEGA.}

Before me, 
Notification.-In St. Augustine, on the same day, month, and year, I notified the preceding decree to Don Jose Fish. I attest. ZULIZARRETTA, Notary.

On the same day, I advised Don Rafael Saavedra de Espinosa thereof, on account of bis agency. I attest.

\section{ZULIZARRETTA, Notary.}

On the same day, month, and year, I made it known to the Accomptant of the Royal Finance, Don Gonzalo Zamorano, as Attorney of the Exchequer. 1 attest.

\section{ZULIZARRETTA, Notary.}

Being on the plantation named Vergel, situated on the island of St. Anastasia, the 10th July, 1795, in conformity with what is ordered in the foregoing decree, the measurement of the land comprised in these proceedings, was proceedell to, and Don Manuel Solano, a skilful person, named for the purpose, proceeded to the place where the quar'ies of the King and private persons are situated, who, passing along the old boundaries, with Don Jose Lorente, master workwan of the Royal Works, who accompanied him for the purpose of being informed thereoni, Don Fadeo de Arribas, officer of the Royal Accomptant office, on account of the occupation of the Atcomptant as Attorney of the Exchequer, and I, the present Notary, placed the stakes, for the purpose of pointing out sail boundaries, according to the width of said island, separating the said quarries, making known that all the rest was what belonged to Don Jose Fish, to whom I, the said Notary, being likewise present, according to the commission conferred on me, gave him possession of the said land pointed out, taking him thereon by the hand, riding together on horseback, over different parts; all of which we done as a sign of having taken quiet and undisturbed possession of the same, without opposition. In testimony of which, and that it may be duly made known, I made out the present returns, which all signed, with the exception of Solano, who said he did not know how; and to all of which I attest.

\section{FADEO DE ABRIBAS, JOSEPH FISH, JOSEPH LORENTE.}

Before me,

\section{JOSE DE ZULIZARRETTA. Notary of Government.}

According to its original, pre-inserted in the proceedings on the subject, to which I refer, and at the request of the party, do seal and sign the present copy, on two leaves of ordinary paper, stamps not being used. St. Augustine. Florida. 29th March, 1798.

JOSE DE ZULIZARRETTA, [x. s.] Notary of Government. 


\section{Translation}

Don Bartolome Benitez y Galiez, Intendant elect, of the Province of $Y$ locos, in the Philippine Islands, and Treasurer of the Royal Finance in this City, received of Don Joseph Fish, resident of this City, 13,880 reals in specie, deposited in these Royal chests under my charge, being the amount of a lot opposite Pedro Garcin, and the plantation called The Vergel, appertaining to the will of his deceased father, which was purchased by him, as is communicated to me from the principal Accountant's Office, in an official letter of the 12th inst. And of the above 13,880 reals in specie, I take charge as a deposite, in virtue of this recoipt, of which an account will be taken by the Accomptant of the Royal Finance, with the approval of His Excellency the Governor, of this said City and Province, on account of the indisposition of the Treasurer, and as his substitute.

13,880 reals in specie.

St. Augustine, Florida, 19th of April, 1792.

\section{PHILIP DE AGUIRRE.}

I took an account of the same.

\section{GONZALO ZAMORANO.}

Approved. QUESADA.

A copy, from the original, on file in this principal Accomptant's Office; and this is made out that it may serve as a security to the interested.

St. Augustine, Florida, 19th April, 1792.

\section{G. ZAMORANO.}

I certify, the foregoing to be a true and correct translation, from a document in the Spanish language.

$$
\text { F. J. FATIO, S. B. L. C. }
$$

\section{Decree.}

The Board having ascertained the above to be a valid Spanish grant for the 10,000 acres of land, do, therefore, recommend it to Congress, for confirmation.

December 16 th, 1825.

Teresa Rodriguez,

The United States, $\}$ For 5,500 acres of Land.

\section{No. 22.}

\section{Memoriaz.}

To the honorable the Commissiomers appointed to ascertain the claims and titles to land in East Florida.

The memorial of Teresa Rodriguez, widow of Miguel Marcos, for and in behalf of herself, and as guardian to her children, the heirs of 
the said Miguel Marcos, respectfully sheweth: 'That your memorialist claims title to a tract of land, consisting of 5.500 acres, situated on the two margins of a creek, running from the west and empties into the river St. John's, about two miles north of a lake known by the name of Long Lake. The mouth of the above creek, is called Big Spring, which said tract of land was granted to the said Miguei Marcos, by Governor Estrada, on the 18th October, 1815, in virtue of varions royal orders, as appears by the original grant in the office of the public archives, in this city, kept by Wm. Reynolds, and a certified copy herewith presented, which land has never been surveyed. Your memorialist further represents, that Don Miguel Marcos, was a resident of this province for many years, in the service of his Christian Majesty ; and that he was legally possessed of said tract when this Territory was ceded to the United States.

\section{TERESA RODRIGUEZ.}

By her Attorney,

St. Augustine, Dec. 1, 1823.

\section{J. W. SIMONTON.}

\section{Transuation.}

Senor Goverxor : Don Miguel Mareos, first Sergeant and SubLieutenant, by brevet, of the corps of royal artillery detached to this city, with all respect, states to your excellency, that he has served his Majesty for forty-one years in this class, and always commissioned by his chiefs for duty of the highest consideration, which, from his capaeity and efficiency, have been placed in his charge; he has furthermore been in several actions, and particularly in the invasion of the year 1812, occasioned by the rebels of the Province, in which he gave the strongest proof of his valor, loyalty and patriotism, always exposing himself to the greatest risks in defence of his $\mathrm{King}$ and religion, in attention to all that is set forth, and availing himself of the royal bounty which his Majesty has been pleased to grant to all the Officers, Sergeants, and Soldiers, and others, who were under arms at that period of 1812 , as respects giving them lands gratis, in recompense for the proofs of valor and enthusiasm with which they have defended their country. For all which he prays your excellency, that, attending to all which has been set forth, and also that he is married and charged with children, you will be pleased to grant him, in absolute property, five thousand five hundred acres of land, which are vacant on the two banks of a creek, which comes from the west and discharges itself into the river St. John, about two miles to the north of the lake known as Long Lake, and the mouth of the said creek, called Big Spring; a favor which he does not doubt to obtain, from the strict justice which your excellency administers.

St. Angustine, (Flonida,) 18th October, 1815.

MIGUEL MARCOS. 
St. Augustine, (Florida,) 18th Oct. 1815.

Let there be granted to the interested on the terms which he solicits, the lands indicated in this memorial, in virtue of the several royal orders, which authorize to that effect, and that he may be able to prove this concession in any event, let the necessary certificate be delivered to him from the Secretary's oflice.

ESTRADA.

I certify the foregoing to be a true and correct translation from a document in the Spanish Language, on file in the office of the Public Archives.

$$
\text { F. J. FATIO, s. B. L. } 0 \text {. }
$$

DECREE.

The Board having ascertained that the foregoing is a valid concession for the 5500 acres of land, made to Miguel Marcos, do therefore recommend it to Congress for confirmation.

December 16, 1825 .

\section{No. 2 .}

John W. Simenton,

The United States. $\}$

For Callo Weso or Key West.

\section{MEMORIAL.}

To the honorable the Commissioners

Appointed to ascertain claims and titles to land in East Florida.

The memorial of John W. Simentun, a citizen of the United States respectfully sheweth,- That your memorialist claims title to a tract of land being the Island of Key West, known also by the title of Thompson's Islaud, containing about 700 acres of land, situated in East Florida, on the southern coast about the latitude of 24 degrees 27 minutes north, longitude 82 degrees 12 minutes west from London, which Island was granted to Juan P. Salas on the 26th of August, 1815 , in consideration of services rendered by him to the Spanish Government, the grant for which Island signed by Estrada, Governor of Florida, was made in virtue of various royal orders, and is deposited in the office of Public Archives, kept by Mr. Reynolds in the city of St. Augustine, a copy of which is herewith presented. And your memorialist further sheweth that he purchased said island for a valuable consideration of the grantor on the 20th of December, 1821 , as will appear by the deed of conveyance from Salas and his wife to your memorialist, recorded in the office of Public Records for the county of St. Johns, on the 2\$d of January, 1822; that under 13. 
the said conveyance your memorialist peaceably took posisession of the said Island on the 19th of January, 1822, when no living persons were on said Island, and has ever since held quiet possession of the same; that he has erected many buildings thereon, and made many improvements. All of which is respectfully submitted.

St. Augustine, 25th November, 1822.

By his Attorney, JOHN'RODMAN.

\section{[TRANSLATION.]}

MEMURIAL.

\section{Senor Governor:}

Don Juan P. Salas, Postmaster of this city, with due respect and submission, states to your excellency that in consideration of the merits and services which he has performed at different periods, both in the corps of royal artillery which garrisons this city as well as that he has voluntarily and without any gratuity served in the office of the Secretary of Government under the command of your excellency, all of which can be proved by legal documents in proper time, and which are well known to your excellency, in virtue of which he humbly prays your excellency to be pleased to grant him in absolute property, one of the Keys known as Cayo Hueso, situated to the south of Cape Florida, a favor which he does not doubt to obtain from the strict justice which your excellency administers.

St. Alugustine, Florida, 23d .August, 1815.

\section{JUAN P. SALAS.}

\section{DECneE. St. Augustine, Florida, 26th August, 1815.}

In virtue of the powers by which several royal orders have authorized this Government to distribute lands to the inbabitants, subjects of his Majesty, gratis, in this province, let there be granted to the interested, in absolute property, the Key named Hueso, included within the limits of this jurisdiction, without injury to a better right; and for a proof of this grant, at all times, let there be issued frotin the Secretary's oflice the necessary certificate.

ESTRADA.

I certify the foregoing to be a true and correct translation from a document, in the Spanish language, on file in the office of the public archives.

\section{FRANCIS J. FATIO, S. B, L. $U$. \\ United States' Commercial Agency.}

Be it known, that, on the day of the date hereof, before me, John Mountain, vice Commercial Agent of the United States of America, 
at Havana, personally came and appeared, Don Thomas de Aguilar, who being duly sworn according to law upon his solemn oath did depose, declare, and say, that he acted as secretary to the following named Governors of East Florida, viz: Don Enrique White, Don Sebastian Kindelan, Don Juan Jose de Estrada, and Jose Coppinger; that he was acting as the secretary of Don Juan Jose de Estrada, in the month of August, 1815; that some time in the said month of August, 1815, Don Juan P. Salas presented a memorial to Don Jose de Estrada, who was then acting as Governor of East Florida, requesting him, the said Estrada, by virtue of the powers vested in him as the Governor of that province, to grant him, the said Salas, the island called Cayo Hueso ; that. in conformity to the memorial of the said Salas, Governor Don Juan Jose de Estrada did grant the said island to the said Salas. some time in the said month of August, 1815 : that this deponent did put the same on file in the office kept for that purpose. This deponent further states that the consideration of the above grant was that the said Salas had in the year 1812, 1813, and 1814, rendered important 3ervices in the suppression of an insurrection in the province, and had afterwards faithfully served in various civil capacities, for which he obtained no other remuneration.

TOMAS DE AGUILAR.

Signed and sworn to before me, the said Vice Commercial Agent, to which $I$ have hereunto subscribed my name, and affixed the seal of my office at Havana aforesaid, the Soth October, 1824.

\section{JOHN MOUNTAIN.}

Know all men by these presents, that we, Juan Pablo Salas, late of East Florida, residing in the city of Havana, Island of Cuba, and Margareta Lorenti the wife of the said Juan, in consideration of the sum of two thousand dollars, to us in hand paid by John W. Simenton, of the State of New Jersey, in the United States of America, the receipt whereof we do hereby acknowledge, have bargained, sold, and quit claimed, and by these presents do bargain, sell, and quit claim unto the said John Watson Simenton, and his heirs and assigns, forever, all our and each of our right, title, and interest, estate, claim and demand, both at law and in equity, and as well in possession as in expectancy, of, in, and to, all that messuage or tract of land called Cayo Hueso or Key West, it being a Key or Island situated on the south coast of Florida, about the latitude of 24 degrees 27 minutes north, and longitude 82 degrees 12 minutes west from London, which Key or Island was granted to the said Juan Pablo Salas on the 26th of August, 1815, by his excellency Don Juan Estrada, then Governor of East Florida, as will appear by the following copy of a memorial and decree of the said Government, viz.

\section{Señor Gobernador,}

Don Juan Pablo Salas, Admr, de Correo de esta plaza ante V. S. con todo respecto, dice en atencion a los meritos y servicios que ba 
contraisdo en distintas epocas, tanto en el Real Cuerpo de Artilleria qui guarnia esta plaza, come en el estuvo voluntariamente $y$ sin gratificacion alguna en la Secretario de Gobierno del mando de V.S., como todo puede acreditarlo con legitimos documentos en tiempo oportuno, y que lo son constantes á $\mathbf{V}$. S. en esta virtudá V. S. rendidamente suplica que teniendo en consideracion lo espuesto se seria concederme en absoluta propriedad uno de los cayos conocido por Cayo Hueso, situado al sur de Cayo Florida ; gracia que no dieda alcanzas de la recta justicia que $\mathbf{V}$. S. administra.

St. Augustine de la Florila, 26 de Agosto de 1815.

\section{JUAN PABLO SALAS.}

Augustine de la Florida, 26 de Agosto, 1815.

En virtud de las facultades que auterizan á este Gobierno varias reales ordine sobre repartimiento de tierras grates á los habitantes vasallos de S. M. en esta provincia se le considere del interesado en absoluta propriedad el cayo nombrado Hueso, correspondiente á los limites de esta jurisdiccion sin perjuicio de mayor derecho y para que pueda hacer constar esta merced en todo tiempo se le despachara por Secretaria la necesaria certificacion.

ESTRADA.

I hereby certify that the foregeing is a true copy of the original which now remains deposited in the office of the Alcalde and Notary Public of the county of St John, province of East Florida, by Wm. Reynolds, the said Juan Pablo Salas, hereby declaring that himself nor any one for him, has ever disposed of to any person or persons, any right, title, or interest, ceded to him by the grant of the said Governor Estrada, of which a copy is herein before written, wi $b$ all and singular the hereditaments and appurtenances thereunto belonging.

In witness wherenf we have hereunto set our hands and seal, at Havanna, this 26th of December, in the year 1821.
JUAN P. SALAS.
Signed, Sealed, and Delivered, in the presence of
John Mountain.
JaMES BarnhaM.

\section{MARGARITE LORATE.}

\section{DECREE.}

The Board having ascertained the above to be a valid Spanish grant for the Isiand in question, made to Juan P. Salas, who sold and conveyed the same to claimant, do therefore recommend it to Congress for confirmation.

December $14 t h, 1825$. 
No. 25 .

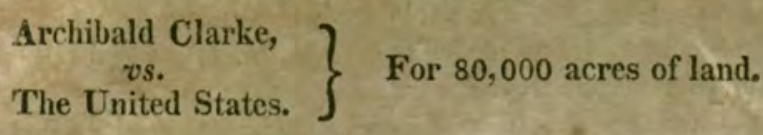

MEMORIAL.

To the Honorable the Commissioners appointed to ascertain claims and titles to lands in East Florida.

The petition of Archibald Clarke, of the State of Georgia, respectfully sheweth, that your memorialist claims title to a tract of land, consisting of eighty thousand acres. situated at or near Cape Florida, bounded on the east by the Atlantic ocean, on the south by Black River Creek, on the west by vacant land, and on the north by the Rio Nueva, as by reference to the plat, herewith affixed, with the evidences of title, will more fully appear. Which title, your memorialist derives from a grant, made to John Arramlide, by provincial deputation, at Havanna, Governor Apodaca presiding, on the 4th day of December, 1813. And your memorialist further sheweth, that he is at this time by his tenants, in actual possession of said lands, that he is a citizen of the United States, and resident of St. Mary's, Georgia. ARCHIBALD CLARKE.

St. Augustine, 17th May, 1824.

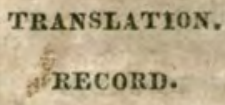

In the city of Havana, on the 12th of January, 1814, I, the undersigned, Notary Public of his Majesty, of the number of this city, in virtue of the orders of Don Ignacio Pedroso, Constitutional Alcade of the same, by a decree of this date, made to a memorial presented by Don Juan X. de Arramlide, I have recorded in continuation said memorial, with the documents accompanying it, which is another presented to the most excellent Captain General, superior political chief of the province, and president of the most excellent provincial deputation, asking for a testimonial of the certified act of the same, passed on the 4th December last, which testimonial appears placed in continuation of it, by the government Notary of this city, and to attest which and said document remaining recorded, I sign these presents. Don Vincente Perez, Don Manual Farnare, and Don Francisco de Silva, residents, being witnesses. JOSE LEAL.

\section{MEMORILL.}

\section{Senor Constitutional Alcade,}

Don Juan X. de Arramlide, a resident of this city, with due respect states, that, requiring that the annexed document be recorded in one of the public offices of this city, in order that the necessary testimonials may be taken from it, he supplicates that your will please to

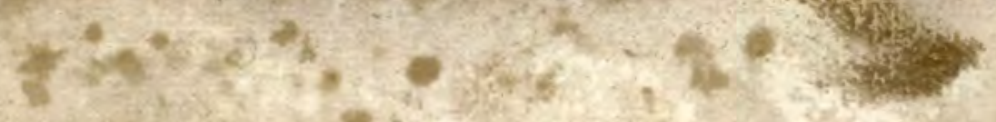


order that it be recorded in the notary's office where he presents it, and that the copies I require be furnished me.

\section{JUAN XAVIER DE ARRAMLIDE.}

Kavana, 12th of January, 1814.

As he asks for

Havana, 12th January, 1814.
PEDROSO, JOSE LEAL:

\section{MEMORIAT.}

Most excellent Sir, Captain General, superior political chicf of this island and the two Floridas, Don Juan X. de Arramlide and Goicocchea, native of Tuesto Real, and a resident of this city, with due respect states to your Excellency, that on the meeting of the most excellent provincial deputation, held on the 4 th instant, it was ordered, that the Fonorable Council of St. Augustine, Florida, should grant me, say two leagues to each cardinal point of the compass, in the territory of that province, for the ends contained in my memorial of the 28th of May of that year. Wherefore, I pray your excellency to be pleased to order the person, whose duty it is to furnish me with an authorized copy of that act, which he hopes for from the justice of your. excellency.

JUAN XAVIER ARRAMLIUE, Y GOICOCCHA.

Havana, 9th December, 181 s.

DECREE.

Havanna, 10th Des. 1813.

Let the memorialist receive a testimonial of the determination stated by him in his memorial.

APODACA.

\section{TESTIMONIAX.}

I certify, that at the session held by the most excellent provincial deputation, the day of the date hereof, presided over by his excellency the Captain General, superior political chief of the province, there was read the report of the commission presented on the 15th of the preceling November, on the solicitation of Don Juan X. de Arramlide, that there should be granted him in property, a certain extent of land in East Florida, with the object of establishing on it mills for saving timber, and of exporting 는 with respect to which, Senor Don Jose Ferregar said, that in the distribution of these Lands, the Letter of the Sovereign Decree of the 4th of January of this ycar, ought not to be observed, but rather, the Laws of the Indies on the matter, as that Decree applies to the division of vacant and Royal Lands in the Provinces already peopled, in which state the Floridas are not, since with the exception of a small part of their Coasts, the 
vemainder of which and the entire of the interior, which is of incalculable extent, remains uncultivated and desert-Arramlide ought, therefore, be considered as one of the settlers of whom the said laws treat; and consequently, the land granted to him in absolute property should not be limited to the small tracts pointed to in said Decree, and having sufficiently discussed the business, the most excellent deputation agreed that in virlue of the conformity manifested by the Council of St. Augustine, Florida, in its act of the 16th of August last, with which the deputation resolved in this case, after having consulted the Captain General, superior political chief of that province, with a certified copy of the present act, the most excellent Deputation were pleased to state to that Council that they grant in property to Don Juan X. de Arramlide, two leagues square to each cardinal point of the compass of the land he may choose, from the mouth of the Rio Nueva, (New River, ) which discharges itself on the Coast of East Florida, and through Punta Larga on the South part, following the same course to the sea shore, permitting him to cut timber without the square set forth, and when the boundary lands are not granted to other inhabitants, prohibiting him from burning them, and offending the Indians, returning the proceedings to the Commission, that they may propose the best mode of distributing the remaining lands, conforming as nearly as possible, to the said Decree.

Havana, 4th of December, 1813.

THOMAS ROMEY, Secretary.

At foot.-This is conformable to the original, which I returned to the office of the Secretary of Government, to which I refer, and in obedience to orders I put these presents.

Havana, 14th December, 1813.

MIGUEL MENDEZ.

This is conformable to the originals, which are recorded with the public instrument in my Archives, to which I refer, and in compliance with orders in the Decree made to the Memorial first copied, 1 give these presents.

Havana, 13 th January, 1814.

JOSE LEAL.

We attest that Don Jose Leal, by whom the foregoing copy appears authenticated, is Notary Public of his Majesty, of the number beionging to this City, faithful, lawful, of entire confidence, and to persons such as him, full faith and credit is given both in law and equity, and to confirm it we agree to give these presents, which we sign and seal with that of our College.

MAURICIO PERRAS PITA, Notary of War. JOSE LORENZO RODRIGUEZ. CUETAN ESQUINEZ. 
I certify, the foregoing to be a true and correct translation of a document in the Spanish Language.

$$
\text { F. J. FATIO, S. B. L. C. }
$$

The most excellent Captain General, states to me under date of the 10th of December last, that which I copy, "Don Juan Xavier Arramlide having solicited that a certain extent of land should be granted him in East Florida, for the reasous and object which he sets forth, I enclose to your excellency a copy of the opinion given me by the most excellent Provincial Deputation on the subject, which $I$ have agreed to, to the end that on your part it may have due course and completion.

Which I pass over to your Honour for your information, and consequent ends, accompanied with a certified copy of the opinion mentioned, receipt of which you will advise of. God preserve you many years.

St. Angustine, the 16 th of March, 1814.

SEBASTIAN KINDELAN.

To the Gentlemen of the Council :

I certify the foregoing to be a true and correct translation, from a document in the Spanish language.

F. J. FATIO, S. B. L. C.

\section{Bahama Islands.}

Know all men by these presents, that I, John Arramlide, of East Florida, but now in Nassau, New Province, have made, ordained, constituted, and appointed, and by these presents do make, ordain, and appoint, James Bixby, of Georgia, (one of the U. S. A.) my true and lawful attorney, for me, and in my name and stead, and to my use, to sell all, or any part or parts, of my tracts of land in East Florida, wherein I reside, containing 90,000 acres, or thereabouts. and $I$ do further empower and authorize my said attorney, to transfer, by deed, whatever he may sell as aforesaid, promising and engaging to ratify and confirm whatever my said attorney may do in the premises. In witness whereof, I have hereunto set my hand and seal, at Nassau, New Providence, this 15th day of July, in the year of our Lord 1817, and in the 57th year of his Majesty's reign.

Signed, sealed, and delivered in presunce of JOHN ARAMLIDE. JOSEPH BIXBY.

\section{STATE of Georgia, \\ County of Camden, $\}$}

This Indenture, made the 1st day of December, in the year of our Lord, 1817, and the Independence of the United States of America the 42d, between James Bixby, of Camden County, attorney in fact for Jean Arramlide, of Havana, in the Island of Cuba, of the onc 
part, and Archibald Clark, of the County and State aforesaid, Attorney at Law, of the other part, witnesseth: 'That the said James Bixby, Attoney in fact, as aforesaid, in hand well and truly paid, the receipt whereof is hereby acknowledged, and thereof, and of every part and parcel thereof, doth acquit, exonerate, and discharge, the said Archibald Clark, his heirs, executors, administrators, and each and any of them. We, the said James Bixby, attorney as aforesaid, and by virtue of the special powers in him, by power of attorney vested, dated and executed on the 15th day of July, 1817, hath granted, bargained, sold, alienated, conveyed, and confirmed, and by these presents doth grant, bargain, sell, alien, convey, and confirm, unto the said Archibald Clark, his heirs and assigns, forever, 80,000 acres of land, being part of that tract of land situated on the coast of East Florida, on the New River, containing 90,000 acres, be the same more or less, bounded Eastward by the Atiantic Ocean, Westwardly by vacant lands, at the time of the issuing of the Royal Grant for the same, a description of the aforesaid tract of land being hereunto annexed, and is intended to form a supplementary part of this Indenture, and which said grant stands on record in the office of the Screvanu, in the town of St. Augustine, in East Florida, aforesaid : to have and to hold the aforesaid 80,000 acres of land, part of the above described tract, with all the improvements, rights, hereditaments, to the same belonging, or in any wise appertaining, unto the said Archibald Clark, his heirs and assigns, forever. And the said James Bixby, an attorney as aforesaid, for him, the said Jean Arramlide, doth hereby warrant and defend the premises aforesaid, the claim or claims of him, the said Jean Arramlicle, his heirs, executors, or assigns, and against the claim or claims of all and every person or persons whomsoever, by virtue of these presents.

In witness whereof the said James Bixby, as attorney as aforesaid, hath hereunto set his hand and seal, at St. Mary's, in the State and county aforesaid, this 1st day of December, in the year of our Lord 1817 , and the 42d year of the Independence of the United States of America.

\section{JOHN ARRAMLIDE, by his. Att'y. in fact, \\ JAMES BIXBY.}

Signed, sealed, and delivered, -in presence of

ANDREW ATKINSON,

R. HOLCOMBE.

\section{DECREE.}

The Board having ascertained the above to be a valid Spanish grant, for the 80,000 acres, made previous to the 24 th January, 1818, do, therefore, recommend it to Congress for confirmation. 
No. 26.

$\left.\begin{array}{c}\text { Joseph Delespine, } \\ \text { vs. } \\ \text { The United States. }\end{array}\right\}$ For 92,160 acres of land.

Memortat.

Territory of Florida, ? East Florida. $\}$

To the Honorable the Commissioners appointed to ascerlain claims and titles to lands in East Florida.

The memorial of Joseph Delespine, respectfully sheweth, that your memorialist claims title in fee simple absolute, in and to ninety-two thousand one hundred and sixty acres of land, situated and being in East Florida aforesaid. Your memorialist shews, that, on the 15th day of November, in the year 181s, one Juan Xavier de Arrambide, a Spanish subject, applied to a certain body or committee, called the "Provincial Committee," then established in the city of Havana, in the Island of Cuba, whose business and duty it was to consider, consult, advise, and determine, as to the most proper and advantageous distribution and disposition of the public lands in the Island of Cuba, and also in the Provinces of East and West Florida, over which its authority in this respect, extended for a grant in absolute ownership and property, of two leagues of land to each point of the compass, for the purpose of erecting saw mills, making rosin, \&c. That the said Committee at its session on the aforesaid 15th day of November, 1813, at which its President, his excellency the then Captain General of the Island of Cuba and of the two Floridas, was present and presided, resolved that the lands solicited by the said Juan Xavier de Arrambide, should be granted to him in complete and absolute ownership and property ; and that bis excellency the said Captain General, at the sairl session of the said Committee, directed that the act or proceedings of the said Committee at their said session, in relation to the said grant of land, should be transmitted to their governor and chief civil magistrate of East Florida, in order that the corporation of the said Province might make a grant to the said Juan Xavier de Arrambide of two square leagues of land to each point of the compass, on the spot which he the said Juan Xavier de Arrambide might choose, from the mouth of the Rio Nueva, which empties itself on the coast of Florida to the Punta Larga, on the south side, running said side up to the sea shore. Your memorialist further shews, that at a regular meeting of the corporation of East Florida, held at St. Augustine, on the 22d day of March, 1814, at which presided his excellency Don Sebastian Kindelan, then governcr and chief civil magistrate of East Florida, a memorial of the said Juan Xavier de Arrambide, dated at the Havana on the first day of February, in the year 1814, was presented, accompanied by an authenticated copy of the aforesaid resolution and act of the said provincial committee, and of the aforesaid order of the 
Captain General, in which memorial, the sail Juan Xavier de Arrambide, after referring to the said proceedings of the provincial committee, and of the Captain General, solicited a grant of the said two leagues of land to each point of the compass, to the north of the river de los Marinies, which lies on the north-west of Cayo Viscayno; that the said corporation, at its said meeting, resolved to grant, and did grant, to the said Juan Xavier de Arrambide, the said lands then solicited by him in full and absolute property, and directed that a copy of this act and proceedings in relation to the claim of the said Juan Xavier de Arrambide, together with his memorial to the said corporation, should be duly authenticated by their secretary, and be directed to him, the said Arrambide, for his security, and as a title to the said land, which was accordingly done; all which will fully and at large appear by a reference to certified copies of the proceedings and acts hereinbefore mentioned and set forth, now here submitted and filed, and marked exhibit A. Your memorialist further sheweth, that immediately after the completion of the said grant, the said Juan Xavier de Arrambide entered upon and took actual possession of the lands embraced by it, and carried a number of persons with him from the island of Cuba, for the purpose of settling the said lands, and of promoting and proceeding in the purposes he had in view in obtaining the said land; that the said Arrambide for several years prosecuted the settlement and improvement of the said land, and the making of tar and rosin, and the cutting of timber thereon, when he was drven from it and compelled to abandon his plans founded on the possession of it, by the hostility of the Indians and fugitive negroes who infested that part of the country; that the said Juan Xavier de Arrambide, by his agent lawfully authorized in that behalf, sold and conveyed the said lands in absolute property to one George J. F. Clarke, a Spanish subject, according to the formalities required by the Spanish law on the 29th day of April, 1820. as will appear-by a certified copy of the said conveyance herewith submitted, and filed and marked exhibit B ; that after the purchase of the said George J. F. Clarke, that is to say on the 7th of May 1821, he applied for and obtained from the then Governor of East Florida an order for the survey of the said land, which will appear from a certified copy thereof herewith submitted and filed, and marked exhibit C. That after the appointment of the surveyor to execute the said order, his acceptance thereof, and preparations made to execute the said survey, it was found that it could not with any safety be attempted on account of the decided and open hosility of the Indians to the whites just at that period; in consequence of which, the design to survey the said land at that time was laid aside ; that, on the 4th day of January, 1822, the said George J. F. Clarke, sold and conveyed the said lands to one John B. Strong, as will appear by his original conveyance thereof herewith submitted, and filed and marked exhibit $\mathbf{D}$; and that the said John B. Strong, for a large and valuable consideration paid to him by your memorialist, sold and conveyed the said lands and their appurtenances to your memorialist in fee simple absolute on the 25th of 
February, 1822, as will appear by the original conveyance thercof to your memorialist, now here submitted and filed and marked exhibit E. Yous memorialist further avers and shows that there are a number of families and settlers established on the said land under the title of your memorialist, at the present time, some of whom as your memorialist believes are persons placed on the said land by the aforesaid Arrambide, at the time he attempted to establish himself on it as aforesaid; and that considerable improvement has been made thereon by clearing and cultivating the ground and erecting buildings. All of which is respectfully submitted by your memorialist.

\section{JOSEPH DELESPINE. By lis Attorney, \\ JNO. DRYSDALE,}

TRANSTATIOK.

RECORD.

In the city of Havana, on the 12th of January 1814, I the undersigned, Notary Public of His Majesty, of the number of this city, in virtue of the orders of Don Ignacio Pedroso, constitutional alcalde of the same, by a decree of this date, made to a memorial presented by Don Juan Xavier de Arrambide, I have recorded in continuation said memorial with the document accompanying it, which is another presented to the most excellent captain general, superior political chief of this Province, and President of the most excellent provincial deputation, asking for a testimonial of the certified act of the same passed on the fourth of December last, which testimonial appears placed in continuation of it by the government Notary of this City, and to attest which and said documents remaining recorded, I sign these presents, Don Vincent Perez, Don Manuel Fornari, and Don Francisco de Silva resident, being witnesses.

JOSE LEAL.

\section{MEMORIAL.}

\section{Senor Constitutional Alcade:}

Don Juan Xavier de Arrambide, a resident of this city with due respect states that requiring that the annexed document be recorded in one of the Public Offices of this city, in order that the necessary testimonial may be taken from it, he supplicates that you will please to order that it be recorded in the Notary's office where he presents it, and that the copies I require be furnished me. Havana, 12th January, 1814.

Havana, 12th January, 1814,

JUAN $\mathbf{X}$. DE ARRAMBIDE.

As hẹasks for

As hęasks for

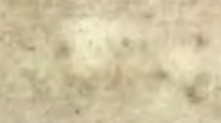

PEDROSO. JOSE LEAL. 
MEMORIAI.

Most Excellent Sir:

Captain General, superior political chief of this Island and the twe Floridas, Don Juan Xavier de Arrambide and Goiwehea, native of Puerto Real, and a resident of this city, with due respect states to your excellency, that, on the meeting of the most excellent provincial deputation held on the fourth instant, it was ordered that the honerable Council of Saint Augustine of Florida, should grant me, say two leagues to each cardinal point of the compass in the territory of that Province, for the ends contained in my memorial of the 28th of May of that year. Wherefore I pray your excellency to be pleased to order the person whose duty it is, to furmish me with an authenticated copy of that act, which he hopes from the justice of your excellency.

Havana, 9th December, 1813.

JUAN XAVIER DE ARRAMBIDE \& GOICOCHA.

\section{DECREE.}

Havana, the 10 th of December 181 s.

Let the memorialist receive a copy of the decision stated by him in his memorial.

APODACA.

cOPY.

I cerify that, at the session held by the most excellent Provincial Deputation, the day of the date hereof, presided over by his excellency the Captain General, superior political chief of the province, there was read the report of the commission presented on the 15 th of the preceding November, on the solicitation of Don Juan Xavier de Arrambide, that there should be granted him in property, a certain extent of land in East Florida, with the object of establishing on it mills for the purpose of sawing timber, and of exporting resins : With respect to which, Senor Don Jose Ferriques sail, that, in the distribution of those lands the letter of the sovereign decree of the 4th of January, of this year, ought not to be observed, but rather the laws of the Indies on the matter, as that decree applies to the division of racant and Royal lands, in the provinces already peopled, in which state the Foridas are not since, with the exception of a small part of their coasts, the remainder of which is of incalculable extent, remains uncultivated and desert. Arrambide ought, therefore, be considered as one of the settlers of whom the said law treats, and, consequently, the lands granted to him in absolute property should not be limited to the small tracts indicated in said decree; and having sufficiently discussed the busi-" ness, the most excellent Deputation agreed, that, in virtue of the conformity manifested by the Council of St. Augustine, Florida, in its act of 16 th of August last, with which the Deputation resolved in this case, after having consulted the Captain General, superior political 
chief of that province, with a certified copy of the present act, the most excellent Deputation were pleased to state to that Council that they grant, in property, to Don Juan Xavier de Arrambide, two leagues square to each cardinal point of the compass, of the land he may choose from the mouth of New River (Rio Neuv) which discharges itself on the coast of East Florida, and the Long Point (Punto Largo,) on the South part, following the same course to the same shore; permitting him to cut timber without the square set forth, and when the bounding lands are not granted to other inhabitants, prohibiting him from burning them, and offending the Indians, returning the proceedings to the Commission, that they may propose the best mode of distributing the remaining lands, conforming, as nearly as possible, to the said decree.

\section{Havana, 4th December, 1813.}

THOMAS ROMAY, Secretary.

At foot. This is conformable to the original, which I returned to the office of the Secretary of Government, to which I refer ; and, in obedience to' orders, I put these presents.

Havana, 14th December, 181 s.

MIGUEL MENDES.

This is conformable to the originals, which are recorded with the public instruments, in my archives, to which I refer, and, in compliance with orders, in the decree, made to the memorial first copied, I give these presents.

$$
\text { [A Cypher.] }
$$

[A Seal.]

Havana, 17 th September, 1814.

JOSE LEAL.

I certify the foregoing to be a true and correct translation from a document in the Spanish language.

F. J. FATIO, S. B. L. C.

Don Juan de Entralgo, Secretary of the Honorable the Council of the city St. Augustine, East Florida.

I certify that, at an ordinary session, held the 22d of March last, at which met Senors Don Sebastian Kindelan, and O. Regan, Knight of the order of St. James, Brigadier of the National Armies, Military Governor and Political Chief, President; Don Jose Sanchez, Constitutional Alcade ; Don Francisco Pons, and Don Pedro Rodriques de Cala, Regidores, and Don Jose Bernardo Reyes, Syndic: They resolved, amongst other things, the following act :

"Resolution. At this Session, the Secretary of the Council has presented a representation, directed to this honorable body by Don Juan Xavier de Arrambide, under date of the first of February last, enclosing a copy of the resolution of the most excellent Provincial Deputations, respecting the concession of two leagues to each point of the compas3, which were made to him, with the consent of the most 
excellent the Captain General, Political Chief of the Island of Cuba and both Floridas, in the Territory of the South side of this Province, soliciting that this honorable body do despatch to him the title of property of the said two leagues of land to the North of the River Miamies, which are on the North west side of Cayo Biscayno ; and the gentlemen agreeing, having in view the said determination of $\mathbf{H}$. E. with an authenticated copy from the said most excellent Deputation, which was communicated to this Council by the President, H. E. the Governor, in obedience as well to the resolution of the aforesaid Deputation, as to the approval of the most excellent Captain General, they determined to grant the favor solicited by Don Juan Xavier de Arrambide, for which ends and that he may be able to prove the title of property which he claims, let the present Secretary deliver to him an authenticated copy of the said representation, and this act, which shall be given him for his security, as a title for the grant which is made to him, with the exception of every thing which, according to the laws, this body ought to know of the business.

\section{Representation.}

To the Honorable the Council :

Don Juan Xavier de Arrambide, with due attention, lays before your Honors, that, it having been determined by this Provincial Deputation, as appears from the act of the 4th of December, and is confirmed by the annexed copy, to grant me in property two leagues to each peint of the Compass, in the Territory on the South part of that Province, for the purposes set forth in my petition of the 28th of May of last year, and what appears likewise from the said act, leaving to my choice the place where I should settle myself, and desiring to effect it two miles to the North of the River of Miamies, which is at the Northwest side of Cago Biscayno, I pray your Honors to be pleased to expedite to me the corresponding title of property, for the two leagues of land to each point of the Compass, agreeably to this situation, reserving to myself to produce the plat of the said lands, and what is made known on the subject, as soon as I find myself prepared to take it out to commence the establishment, which $I$ am to effect.

\section{Havana, the 1st of February 1814.}

JUAN XAVIER DE ARRAMBIDE.

This is a Copy.

JUAN DE ENTRALGO, Secretary. St. Augustine, Florida, the sd June, 1814.

Don Manuel Lopez Garcia, Ministerial Officer, and Royal Collector of the National Chests of the City of St. Augustine, Florida, and Don Jose Antonio Yguines, Treasurer, pro tem. of them.

We certify, that Don Juan de Entralgo, by whom the foregoing certificate is signed, is Secretary of this honorable Council, as he styles himself, a Notary pro tem. of the Government, in this City, 
the only one in it-and in its Province,-and to such persons as him, full faith and credit is given, both in Iaw and equity.-To confirm which, we sign these presents at the request of the party, in this City.

MANUEL LOPEZ,

JOSE ANTONIO YGUINEZ.

St. Augustine, Florida, the 6th of June, 1814.

I certify the foregoing to be a true and correct translation, from a Document in the Spanish language.

F. J. FATIO, S. B. L. C.

\section{TRANSIATION.}

POWER.

Be it known, that I, Don Juan Xavier de Arrambide y Goicocha, resident of this City, declare that I give my power, full and sufficient, as may be required and necessary in law, to Mr. Jobn B. Strong, a citizen of the United States of America, general that he may charge, defend, liquidate, sell, and finish whatever affairs may appertain to, or concern him in the said States, with a revocation of every other power, paticularly that granted in favor of Don John Forbes, as $\boldsymbol{I}$ declare of no value, whatever document may have reference to it, and especially for the sale of the lands I have in East Florida, delivering the respective writings which he may make, valid and firm, as if $\mathbf{I}$ myself were present in person, and in case of necessity, sue with writ. ings, witnesses, proofs, other documents and papers which he may take possession of, wherever they shall be found; make protests, citations, and summonses, demand executions, captions, discharges, detention, and releasing of property, sale, sale to pay debts, and auction of what he would take possession of, should it be adjudged to him, and for every kind of proofs, the necessary terms, and renounce them, power to delegate warrants to comply, precepts, and commissions, which he may cause to be read publicly, and made known to whomsoever and wheresoever he finds it necessary. He may see and examine witnesses presented and sworn on the adverse side, make objections to find defects in them, be surety for persons, and vouch for depositions, make oaths and recusations, hear and bring to a conclusion judicial decrees, and interlocutory and definitive sentences, consent to what is favorable, and petition and appeal from what is adverse, instruct and direct appeals, and whatever competent legal courses he can and ought to pursue ; finally, to proceed, act, and do all other matters, judicial, and extra judicial, required in any of my affairs, for which, and all incidences and dependencies, $I$ give this jower without limitation, with free and general administration, power of commencing suits, swearing, sustaining them, and concluding them himself, in compromising them through arbitrator's, juries, or friendly referces, and exonerating the parties in form. For the firmness and accomplishment of what he shall perform in virtue of this, I bind present and future property, poiver of tribunals, and renunciation of 
laws. In testimony of which, this is dated in this City of Puerto Principe, the 17th of January, 1820, I, the Notary of the Council, attest, that I know the granter, who said as is set forth, and signed this, there being witnesses present : Don Pedro de Sespedez, Don Rio de Evia, and Don Ramon de la Torre.

JUAN XAVIER DE ARRAMBIDE, \& GOECOECHA.

Before me.

JOSE RAFAEL CASTELLANOS.

This is conformable to the original, to which I refer, and at the desire of the party, caused it to be written.

Puerto Principe, the 20th January, 1820.

JOSE RAFAEL CASTELLANOS.

This is conformable to the original, which exists in the archives in my charge, to which I refer, and by desire of the party sign and seal the present copy on two leaves of common paper, the stamped not being in use.

St. Augustine, (Florida,) 20 th of April, 1820. JUAN DE ENTRALGO.

I certify the foregoing to be a true and correct translation from a document in the Spanish language.

$$
\text { F. J. FATIO, S. B. L. C. }
$$

TRANSIATION.

CONVEYANCE.

Be it known, that I, John B. Strong, citizen of the United States of America, at present a resident of this city, and attorney of Don Juan Xavier de Arrambide Goicoechea, resident of Puerto Principe, in the Island of Cuba, as appointed by him, before the Notary of that Council, Don Jose Rafael Castellanos, the 17th of January, of the present year, a copy of which shall be added in continuation, and is sufficient for what shall be said, I declare that I really sell to Don George Clarke, an inhabitant of this Province, Surveyor General in it, two leagues of land, to each point of the compass, which is in square in the Territory on the south side of this Province, situated about two leagues to the north of the river Miamies, which is in the northwest side of Cayo Biscayno, and is between the mouth of Rio Nuevo, (New River,) which discharges itself on the coast of Florida, and the Long Point on the south side, following the same course to the sea shore, which land was granted to me in full property by the Constitutional Junta of this city, by an act passed the 22d of March, 1814, in virtue of the determination of the most excellent Captain General of the Island of Cuba and both Floridas, communicated with an authenticated copy of the 
opinion of the most excellent Provincial Deputation. And I sell him the said two leagues to each point of the compass, on the terms and under the circumstances on which they were granted to my said principal Don Juan Xavier de Arrambide Goicoechea, with its pastures, woods, water entrances, outlets, uses, customs, rights and services, in the manner which corresponds to him, and that he may use it for himself and his successors, free of all incumbrance (as I the Notary certify from the result of my search of the Book of Mortgages, in my charge, which I have made for the purpose) at the price of $\$ 20,000$, which the purchaser has paid me in current money, which I acknowledge as delivered to my will. I renounce proof, laws of delivery, exception to money not counted, fraud, and every thing else in the case, for which I deliver a receipt in form, in virtue of which, I separate my principal from the right of property, possession, use, seigniory and other actions, real and personal, which he had and held to said lands, as I cede, renounce and transfer it to the purchaser and his representatives, that as his own he may take possession in the manner most convenient to him, by virtue of this deed, by which he may dispose at his will, of the thing acquired without occasion for further proof, from which I relieve him. And I bind my principal to the execution and guarantee of this sale, in sufficient form, and as may best suit in favor of the purchaser, with the goods of my principal, present and future, power, and submission to the tribunals of this Domicile, that they may compel him to its performance, as by sentence consented and passed in authority of an adjudged case, in which I renounce all the laws, customs, rights and privileges in his favor, and the general law in form which prohibits it; and I, Dou William Travers, being present, by order of the purchaser, Don George Clarke, accept in his favor this deed, and by it receive as purchased the said lands at the price and agreement on which they have been sold to him, which he gives as delivered to his will, with a renunciation of proof, laws of delivery, those of a thing not seen or received, fraud and every thing else in the case, for which I deliver a receipt in form.

In testimony of which, this is dated in this city of St. Augustine, Florida, the 29th of April, 1820.

I, the Notary, attest that the parties said thus and signed it, there being witnesses Don Bernardo Sequi, who served as interpreter, there being no public one, Don Pedro Miranda and Don Fernando de la Maza Arredondo, jun. inhabitants, present.

JOHN B. STRONG, WHLLIAM TRAVERS.

As Interpreter, Bernardo Sequi.

Before me,

JUAN DE ENTRALGO, Notary of Government.

I certify the foregoing to be a true and correct translation from a do. cument in the Spanish language.

F. J. FATIO, S. B. L. C. 


\section{State of South Carolina.}

Know all men by these presents, that I, John B. Strong, of the city of St. Augustine, in East Florida, but at present in Charleston, in the State aforesaid, for and in consideration of the sum of 20.000 dollars, to me in hand paid, by Joseph Delespine of the same place, but at present in the city of Charleston, in the State aforesaid, have granted, bargained, sold and released, and by these presents do grant, bargain, sell and release, unto,the said Joseph Delespine, all that certain piece or parcel of land, situate, lying, and being in the southern part of the Province of East Florida, of two leagues of land to each point of the compass, on the northern part of the river de los Maimes, which lies to the northward of Cayo Vescayno, or Key Biscayno, and which said tract of land contains 92,160 acres, be the same more or less, and which said tract of land was granted to Juan X. de Arrambide, by the Captain General of the Island of Cuba and of the two Floridas, and confirmed by the Governor and Corporation of East Florida, and was sold to me by the said Arrambide, in Puerto Principe in the Island of Cuba, in the month of July, 1819, and for a more particular description of said tract of land, and every thing relating thereto, more particular reference may be had to the original grant made to the said Juan X. Arrambide-together with all and singular the rights, members, hereditaments, and appurtenances to the said premises belonging or in any wise incident or appertaining-To have and to hold, all and singular, the premises before mentioned, unto the said Joseph Delespine, his heirs and assigns forever. And do hereby bind myself, my heirs, executors, and administrators, to warrant and forever defend all and singular the said premises unto the said Joseph Delespine, his heirs and assigns, against myself and my heirs, and all other persons lawfully claiming or to claim the same or any part thereof.

In witness my hand and seal, this 25th day of February, in the year of our Lord, 1822, and in the 46th year of the Independence of the United States of America.

Signed, sealed, and delivered, in the presence of

\section{JOHN B. STRONG.} Wм. W. CоRмick, THomas W. HoLWELL.

\section{DECREE.}

The Board having ascertained the above to be a valid Spanish grant for the 92,160 acres, made previous to the 24th January, 1818, do therefore recommend it to Congress for confirmatiou.

December 14.

\section{Georgia, Camden County:}

This indenture, made this 4 th day of June, 1822, between George J. F. Clarke, of the Province of East Florida, on the one part, and John B. Strong, of said Province, on the other part, witnesseth; that 
the said George J. F. Clark, for and in consideration of the sum of one dollar, to him in hand paid, at and before the sealing and delivery of these presents, the receipt whereof is hereby acknowledged, hath granted, bargained, sold, and conveyed, and, by these presents, do grant, bargain, sell, and convey, unto the said Strong, a quantity of land lying in the Southern part of said Province, situated two leagues North of the river Miamie, which lies to the Northwest of Key VIscayno, and containing two leagues measurement to each wind, as will more fully appear by the grant thereof, made by the Spansh Governor to John X. Arrambide, which said quantity of land was sold to Clarke by said Strong, as the Attorney of said Arrambide, as per an instrument executed on the records of St. Augustine, East Florida, on the 29th of April, 1820. To have and to hold, unto him, the said John B. Strong, his heirs and assigns, the said lands, in the same state that he, said Clarke, received them from him. And the said George J. F. Clarke, for himself, his heirs, executors, and administrators, unto the said John B. Strong, his heirs and assigns, will forever warrant the said bargained premises only against themselves.

In witness whereof, the said Clarke hath hereunto set his hand and seal, the day and year above written.

Signed, sealed, and delivered, in the presence of

GEO. J. F. CLARKE. James BenthaM, Thos. H. MmLer, J. J. C. C. C.

No. 11.

Francis P. Fatio, \&c.

The United States. $\}$ for 10,000 acres of land.

\section{Memoriat.}

To the Honorable the Commissioners appointed to ascertain claims and titles to lands in East Florida.

The petition of Francis P. Fatio, for himself and his sister Louisa Hallows, heirs of F. P. Fatio, deceased, respectfully sheweth : That your memorialist claims title to a tract of land consisting of ten thousand acres, situated on the East side of the river St. John's, about sixty miles from its mouth, and thirty miles from the city of St. Augustine, bounded on the North by Wm. Harvey's lands; on the Sonth by F. M. Arredondo, Senr.'s lands ; on the East by vacant pine lands ; and on the West by the river St. John's. The first line commences at a stake at the edge of the said river, marked with a cross, and runs S. 45 E. 22 chains, and ends at a pine with the same mark. The second line begins at the last, and runs N. 45 E. 80 chains, and ends at a stake with the same mark. The third line begins at the 
last metioned and runs S. 45 E. 320 chains, and terminates at an oak, with the same mark, on the banks of said river; thence, along the meanders of the river, binding thereon, to the beginning; as is seen by a plat and certificate, made by Pedro Marrot, and dated November 25,1791 , and marked A, which title your memorialist derives from a British grant, made to Francis P. Fatio, deceased, by Governor J. Grant; that the British titles to said lands were lost during the troubles in the province, in the year 1812, when memorialist's houses were burnt, and himself and family were obliged to fly, being robbed of considerable property and negroes. And your memorialist further sheweth ; that he is in actual possession of said lands ; that he is a citizen of the United States, and resident at Florida. All of which is respectfully submitted.

\section{F. P. FATIO.}

\section{Transhation.}

Don Pedro Marrot, Captain of the Sd Battalion of the Infantry Regiment of Cuba, and Judge, commissioned by the Governor and Commander in Chief of this Province of East Florida, for the surveying and laying off lands ordered to be distributed by command of His Majesty.

I certify that, at the plantation called New Switzerland, there have been measured three hundred caballerias of land, which, as appears by the titles of his Britannic Majesty, which have been exhibited to me, consists of ten thousand acres, belonging to Don Francisco Philip Fatio. The first line begins and runs to the South 45 degrees East, and contains 22 chains, beginning by a picket marked with a cross, on the bank of the river St. John's, bounding in part with the lands belonging to Hannah Moore, and ends with a pine tree of the mark of a eross; follows on the North 45 degrees East to a lightwood stake marked with a cross, and the survey contains 80 chains. The second line runs and begins with said stake to the South 45 ciegrees, to the Erast to a pine tree marked with a cross, and its survey contains 320 chains. The third line runs South 30 degrees West, begins with said pine and ends with an oak marked with a cross, on the bank of the river St. John, and its measurement cousists of 318 chains; its front runs on the bank of said river. Agreeably to the orders which I have, the interested signed this, with the Surveyor, Don Samuel Eastlake. And for its confirmation, and that it may serve for the information of the Secretary of this Government, to whom the interested will have to apply for their respective titles, I give these presents at Switzerland, river St. John's, the 25 th of November, 1791.

PEDRO MARRO'T.

SAMUEL EASTLAKE.

[Here follows a plat of the land claimed.]

I certify the foregoing to be a true and correct translation from a document in the Spanish language.

F. J. FATIO, S. B. L. C. 


\section{DECREE BY THE BOARD.}

In this case, we find that Pedro Marrot, by order of the Spanish Government, surveyed the land on the 25th of November, 1791, for F. P. Fatio, father to claimant, (as per plat and certificate of survey, that, on division of the estate of F.P. Fatio, deceased, this tract was allotted to claimants ; that Francis P. Fatio took the oath of allegiance to His Catholic Majesty, and was in possession of the land until his death. The Board ascertain this to be a valid claim; they, therefore, recommend it to Congress for confirmation.

September 15 th.

\section{Francis P. Fatio, \\ United States. $\}$ For 10,000 acres of land.}

Francis Marien being duly sworn, says that he knows the above tract of land, and has known F. P. Fatio, Senior, to have resided on the said tract upwards of twenty years. Witness has been frequently on the said plantation, and that there were some very fine buildings thereon, until they were burnt by the Indians and Patriots in the year 1812. And witness further states, that it is well known to all the old inhabitants of this Territory that claimant was in possession of said land, since the cession of this Province to Spain.

Before the Board in Session, ?

\section{FRANCISCO MARIEN.}

September 1st, 1824. $\}$

William Reynolds being sworn, states that he believes the signature of Pedro Marrot, which is attached to the Document exhibited to him in this case, is the same as that which is attached to the original documents in the office of the Public Archives of St. Augustine under his charge.

Before the Board in Session,

September 15, 1824.

WILL. REXNOLDS.

St. Augustine,

January 1st, 1826.

\section{Honorable Richard Rush,}

Secretary of the Treasury, Washington.

SIR: Since our last report the claims to lands in East Florida, accompanying this communication, have been investigated and decided upon by the commissioners. With the greatest diligence and industry our Secretary, (and the two additional clerks appointed by authority of the law of the sd of March last) have not been able to translate 
and copy the whole of the claims filed before us. There now remains to be acted on five hundred and twenty-eight.

From an inspection of the documents now forwarded, you will readily perceive that no want of industry has been manifested by the efficers of the Board. We last year urged the propriety of our being allowed by Congress the privilege of employing clerks and translators at discretion, at a rate for every hundred words written or translated. This however was denied, and hence the business before the commissioners is not yet completed.

For the principles on which the Board have acted, they beg leave to refer to the former reports made by this Board, as they have not in any material degree varied from thein in the cases now reported.

Register No. 9, embraces a class of cases rlifferently situated, in some respeets, from any yet reportel, for, at the time of the cession they were not found amongst the records of Government, the only proper place for them; those circumstances have, in some cases, been explained, or an effort at explanation has been attempted, that the evidence introduced, although perfectly competent by the legal rules of evidence, we feel bound to say that it has not always been of that clear disinter. ested character which is calculated to carry conviction to the mind.

Most, if not all the witnesses, have been interested in the principle decided, although not interested in the particular case before the Board. We have forwarded the testimony as nearly in the phraseology of the witnesses as practicable. To that testimony, and that which relates to Tomas de Aguilar, one of the oflicers of the government, we beg leave particularly to refer. The cases which have been reported as finally acted upon, the commissioners have been as particular as the reason of the cases would justify, and have generally demanded strict proof of the right of the party, so far as the United States are interested, but in the arrangement of title we have not been particular, as our decisions can in no case prejudice the rights of individual claimants, and where a clear equitable right against the United States has been proved by one claimant, we have considered ourselves at liberty to relax in the rules in behalf of a second claimant for the same land, otherwise, (if our decision be correct,) we might have done justice, but would not have given public satisfaction.

We have the honor to remain,

Your most obedient servants,

DAVIS FLOYD,

WM. H. ALLEN.

\section{STATEMENT.}

Claims remaining in the office not yet translated, . ...

Claims translated but not prepared, because the claimants have not adduced their testimony, ......

Donation claims undecided, _. _........

British claims undecided,

Total claims in the oflice, . . . . . 528 
Recapitulation of Claims acted on this Session.

Confirmed under 1000 acres, - _ - . - . - 173

Reported for confirmation over 1000 acres, $\quad-\quad-\quad-\quad 10$

Reported under the donation act, - - - - - - - 13

Confirmed under the donation act, _. - . - . - 10

Rejected, - . . . . . . . . . 21

Undefined in quantity and reported, . . . . . 64

233

\section{To the Honorable Rrcrino Rush,} Secretary of the Treasury.

The undersigned commissioners, for ascertaining claims and titles to lands in East Florida, report, that, in the discharge of the duties assigned them, they have examined and disposed of the claims herein set forth, in the manner, and upon the principles exhibited in the following nine classes, numerically arranged :

Number one, is a class of claims, as per Register transmitted herewith, to lands not exceeding 3,500 acres in quantity, and which have been confirmed by the Board. This class of claims is founded on Royal titles, and on concessions, some of which are unconditional, and others conditional. A Royal title is the highest order of title known by any law, usage, or principle, in the Province of East Florida; titles of this description were designed to convey the fee simple to the grantee; they were usually made by the acting Governors of the Province in the name of the King; they decided the grant to be in "perpetuity ;" and, also, the specific metes and bounds of the land, although it is believed there were a few exceptions. This title may be said to correspond in character with that of a patent issued by our Government. Concessions, without condition, are understood to differ from a Royal title only in this, that most of the latter recite the metes and bounds, whereas, the unconditional concession, although definite in quantity and location of the land, is still subject to a survey, which, when made, was followed up by maturing the concession by a Royal title. In concessions with conditions, it was always expected, by the Spanish authorities, that the grantee was to comply with them, and not until then, could he obtain a Royal title; yet, on proof of conditions performed, it is believed that they were never very rigorous. Orders for survey were generally predicated upon concessions previously granted, yet a few have come before the Board that were not. but were made by the Deputy Governor, (as stated in his testimony, by virtue of a verbal order of the Covernor; in no case, however, has the 
quantity exceeded 640 acres, which has been confirmed; and then, not until the document proved that the grantee had been in the actual possession and cultivation of the land, at, and before the 22d day of February, 1819. In deciding on the cases comprehended in this class, the Board have, in all cases of Royal titles and concessions without condition, where the documents were found amongst the archives of the country, and no allegations on the part of the United States appearing against them, have considered themselves bound to grant certificates of confirmation to the claimants. And in all, exceeding 1000 acres, and not exceeding 3,500 , where the parties, in addition to the preceding qualifications, proved that they were in the actual possession and cultivation of the land, at the time of the cession, the Board have also consi lered themselves bound to grant certificates of confirmation, as well as in the cases of concession with conditi $n$, where the claimants, in addition to the qualifications mentioned, proved also the conditions to have been substantially performed.

Number 2 comprises claims not exceeding 3500 acres, which, although found to be valid Spanish grants, yet have not been confirmod from the want of proof of actual possession and cultivation at the time of the Cession : they consist of Royal titles and concessions, as in class No. 1.

Number 3 comprehends claims exceeding $\$, 500$ acres, the titles to which, were found amongst the public archives of the country, and are ascertained by the Commissioners to be valid Spanish grants, and reported accordingly to Congress, for confirmation. On this class the Commissioners think it necessary to remark, that, although the subject has continued to engage their attention, they have perceived no principle calculated materially to alter their rules of adjudication, as set forth in their first report. From the most correct information they have received, they are of opinion that the rules for granting lands were in East Florida different from those established in the other Spanish Provinces: In East Florida, the Governors seem to have exercised a discretion in granting lands for various purposes, to all such as made application for them ; but the Commissioners have been much perplexed in endeavoring to ascertain the limit of their authority ; hitherto their researches have been in vain. That this discretionary power was uniformly exercised by the Governors, is clearly to be inferred from their own acts ; for the first Governor, after the cession of the Province in 1783, made no grants of lands, or but few, and those only in small quantities; the one who succeeded him (Governor Quesada, ) established and published rules and regulations for the distribution of the Public Lands, one of which was the appointment of a Commissioner, who, with the assistance of a Surveyor, was specially entrusted with the distribution of the Public Lands, this they did in the following proportions : to the heads of family one hundred acres, and to each other member, of whatever age, sex, or color, fifty acres; nevertheless, it is found that Governor Quesada made grants in violation of those rules. His successor (Governor White,) established rules differing from those of Quesada, and reduced the quantity, to be

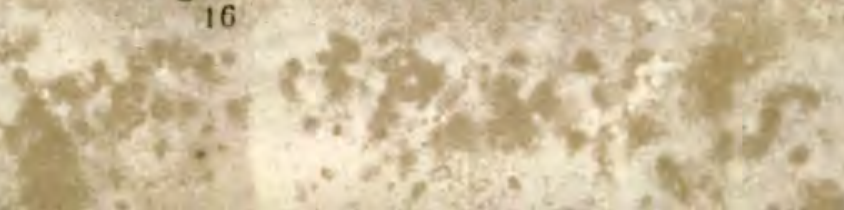


given to the heads, and other members of a family, ant added the condition of ten years possession, before the party should be entitled to a Royal title ; and White, also, is found to deviate in some cases from the rules established by himself, as well as those of Quesala. There is, also, a peculiarity in the phraseology of a Royal title; in all the grants of this nature, the legal right to grant the lands is asserted, firom which it is clearly to be inferred, that the Governors considered themselves entitled to, and did exercise a discretionary power to grant the public lands to those who might make application for them, in such quantites as they conceived might tend most to encourage the population and improvement of the country. By examining the correspondence between the King and the Intendants it will be found that they were particularly charged, and especially in East Florida, to promote the population and improvement of the province, by all the r prudential means in their power. To this end, the Commissioners find all the Governors giving grants of land for the declared purposes of agriculture, pasturage, grist and saw mills, as well as indemnity for losses, and for military services, each of which, seem to be embraced in the discretionary exercise of gubernatorial power. The Commissioners trace this exercise, with a few exceptions, up to the year 1814, about which period, whether from a change of policy as applicable exclusively to the Province, or connected with an expected transfer to the United States, a practice of distribution was introduced, differing from the former in the magnitude of the grants. Some of these grants favor the belief, that the gratification of individual cupidity may have had some influence in their formation, but how far they comport with the laws of Spain, and are entitled to confirmation, the Commissioners submit to the superior knowledge of Congress. There is one rule which the Commissioners suppose it would not be unreasonable to apply in the adjustment of these claims. In cases where an application shall have been made for a grant of land, as a remuneration for services, or other object, embraced in the policy of the Government, and the grant shall have been matle accordingly; if the same individnal shall have made a second application for remuneration for the same services, it would be no more than just to suppose that the first concession was full and ample, unless otherwise recited in the grant itself, and that the subsequent grant was an assumption of power not warranted by the laws and usages, nor the policy of the Government.

Number 4 comprehends claims under the donation act of May, 1824, and not exceeding 640 acres, and which have been confirmed by the Board, upon satisfactory proof that the claimant was twenty-one years of age, the head of a family, and that he had never received any written evidence of title, from either the British or Spanish Governments of East Florida, and furthermore, that he was actually settled on, and cultivating the land at, and previous to the 22d February, 1819, according to the requirements of said act.

Number 5 comprises a class of claims, reported to Congress, on the ground that the settlements were made between the 27 th February, 
1819 , and the 17 th July 1821 , the time of the cliange of Government, and originating under the aforesaid donation act.

No. 6 comprehends claims derived from the Spanish Government, by written evidence, and which have been ascertained to be valid Spanish grants, and have been reported to Congress on the ground that they were undefined in quantity.

No. 7 , comprises claims, not exceeding 3,500 acres, founded on British grants. which have been recognized by the Spanish authorities, and confirmed by the Board, upon proof of such recognition, and, in cases over 1,000 acres, on proof of actual occupation and cultivation.

No. 8 is a register of town lots and out lots, founded on actual occupation and cultivation previnus to $22 \mathrm{~d}$ February. 1819, and which have becn confirmed upon proof that they were actually in possession at and previous to the aforesaid day, by and with the consent of the Government.

No. 9 is a class of claims, differing from all the others in an apparent want of formality. The other claims were authenticated by documentary evidence, filed in the office, and were entitled to all the legal presumption in their favor, which applies to records in our Government ; but the claims of this class were found in the posses:sion of the claimants, and without any trace of evidence in the archives, and this circumstance, coupled with the equivocal character of the officer who verifies them, casts a shade of suspicion over the whole. In the investigation of these claims the Commissioners have required the parties to show reasons. why they were not on file in the archives. as well as to prove the execution; but, from the interested character of the witnesses produced, the evidence on these points has been hitherto inconclusive; thinking it probable. however, that some, if not many of these claims are good and valid. and being informed by the parties of their ability to remove the suspicion, the Commissioners have thought it due to justice, that their opinion be suspended, and that a reasonable time should be afforded for the production of testimony.

With the outline afforded by the preceding classification, the Commissioners transmit the documentary evidence, and their opinions thereon in each case in detail. This arrangement of their opinion was suggested by the act by which the Board was created, which dictated a minute transcript and investigation of the records, and a periodical accountability to the Secretary of the Treasury; and it was further enforced by the necessity of adjudicating on principles between which no summary can aftord an absolute or definitive line of demarkation; and if the documents transmitted should be considered voluminous, it will, at the same time, be perceived, that the features of the claims are various, and that the Commissioners in their operations have been guided by the injunctions of the law. These operations have been retarded by the labor which was unavoidable in translating and transcribing the original grants and mesue con- 
veyances, and the inadequate assistance afforded by the employment of three Clerks, for which number only the law provides.

The operations of the Board, independently of those contained in the first report, have resulted in the confirmation of 326 claims ; in the rejection of 61 ; and in a reference to Congress of 88 . Besides these claims, there are 528 undetermined, of which 233 are held under advisement for further proof, and, 295 although filed, have not been matured to translation; and the Commissioners being sensible, that the public interests demands an acceleration of the adjustment of these claims, have to suggest, as a mean of promoting this object, that the work of transcribing and translating be performed for a pro rata compersation.

All which is respectfully submitted.

Washington 31st January, 1826.

\section{DAVIS FLOYD, W. H. ALLEN.}

My friend and colleague, Mr. Floyd, having addressed the above letter to you previous to my arrival at Washingtinn; and approving highly of its remarks in general on the different Abstracts, I have signed the letter without requiring any alteration. But of course I should not be considered as participating in such remarks on Abstract No. 3, as are only applicable to the cases acted on by him and Mr. Blair previous to my being a Member of the Board.

Your's, respectfully,

Eionorable Rrchard Rush,

W. H. ALLEN.

Secretary of the Treasury.

LaNd OfFice, Western District,

Orleans Territory, October 16, 1812.

To the honorable Albert Galiatin, Secretary of the Treasury of the United States:

The undersigned, Commissioners appointed for the purpose of ascertaining the rights of the persons to lands within the District and Territory aforesaid, have the honor to report the following list of rejected claims; and beg leave to remark, in explanation of the said report, that the respective classes contemplated by the 8 th section of the act of the third of March, 1807, will be designated by the letters A, B and C ; to wit : to the first class, comprising "claims which, in the opinion of the Commissioners, ought to be confirmed in conformity with the provisions of the several acts of Congress for ascertaining and adjusting the titles and claims to lands within the Territory of Orleans and Louisiana," the letter A will be affixed. To the second class, comprising "claims which, though not embraced by the 
provisions of the said acts, ought, nevertheless, in the opinion of the Commissioners, to be confirmed in conformity with the laws, usages, and customs of the Spanish Government," the letter B will be affixedAnd to the third class, comprising "claims which neither are embraced by the provisions of the said acts, nor ought, in the opinion of the Commissioners, to be confirmed, in conformity with the laws, usages, and customs, of the Spanish Government," the letter C will be affixed. In the subsequent list of claims, such as have been entered with Deputy Registers, will have the letter D placed after the number, in the column of Registers' No. When that letter is omitted, it is to be understood that the claim was entered with the Register at the Land Office in Opelousas. To the list of claims reported for each county, will be subjoined explanatory remarks, with references to the reported numbers, containing the reasons of the Commissioners for reporting, and giving a schedule of the title papers that may have been filed in the several claims, and the substance of such oral testimo. ny as may have been taken for or against the claims. 
good title in Ledee. The evidence of Andre Martin, establishing the occupancy of the land, as required by law. The depth is unknown to the commissioners, not having been able to procure a survey of the land, and the operation under the Spanish government being confined, as is supposed, to a measurement of the frent, and giving the direction of the lines of depth as was the usage of the country, but of which no plat having been filed, the quantity of land must be determined hereafter by survey.

No. 3. Marie Babin, widow of Claude Martin, claims ten arpens of land in front, on each side of the Bayou Teche, with the depth of forty-two on the east side, and on the west with the depth from the said Bayou Teche to the Bayou Vermillion, by virtue of a grant in favor of Francois Ledee for a larger quantity, sold at vendue by parcels, and bought by Claude Martin at said vendue, as may be seen by papers filed in the claim of Pierre Brossard, in the Register's office. The notice of this claim is unaccompenied by any document of title. Louis Judice, before the board the 21st August. 1811, hath deposed. "that the land claimed is a part of Ledee's grant for a larger quantity, and hath been inhabited and cultivated for more than forty consecutive years preceding this day." This claim ought, in the opinion of the commissioners, to be confirmed for so much land as may, from resurvey, be fuund to be within the limits of the grant to Ledee.

No. 4. Placide Bossier claims 640 acres at a place called St. Maurice, purchased from the heirs of the deceased Peter Derbanne, who settled and possessed it from the year 1772 to the time of his death, 1796 The notice of this claim is unaccompanied by any document of title. Silvestre Bossie, aged 46 years, brfore the Board the $23 d$ February, 1813, hath depesed, "that the land claimed has been settled, inhabited, and cultivated, from the year 1786 until about eight or nine years ago. by the said deceased, Derbanne, and those claiming under him." Having stated in his notice that the land was purchased from the heirs of Pierre Perbanne, it was incumbent on the claimant to adduce the deed of sale. by which the quantity and situation of the land would probably have been explained. The commissioners are of opinion the claim ought to be confirmed for the quantity of land which shall appear to have been conveyed, not exceeding 640 acres.

No. 5. The legal representatives of Daniel Callaghan, deceased, claim 177 superficial arpens of land on the waters of Bayou Bellevue, by virtue of an order of survey in favor of said Callaghan bearing date the 3d of April, 1788, for six arpens front, by the depth of forty arpens; out of which order of survey there has been confirmed to Louaillier's brothers, twelve arpens, by commissioner's certificate B, No. 1900 ; to William McKoy, by certificate No. 1901, thirty-six arpens; and to the inhabitants of the county of Opelousas, fifteen arpens, by certificate B, No. 2278 , leaving the above quantity. 177 arpens, for which no regular entry has been filed. but of whicb the commissioners recommend the confirmation to the legal representa- 
To the Honorable Josrat Mergs, Commissioner of the General Land Office in the Treasury Department.

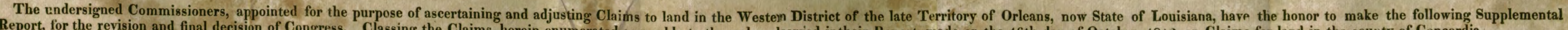

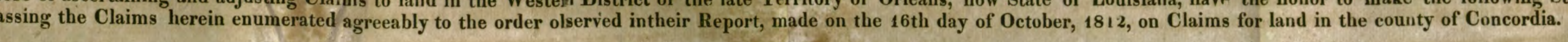

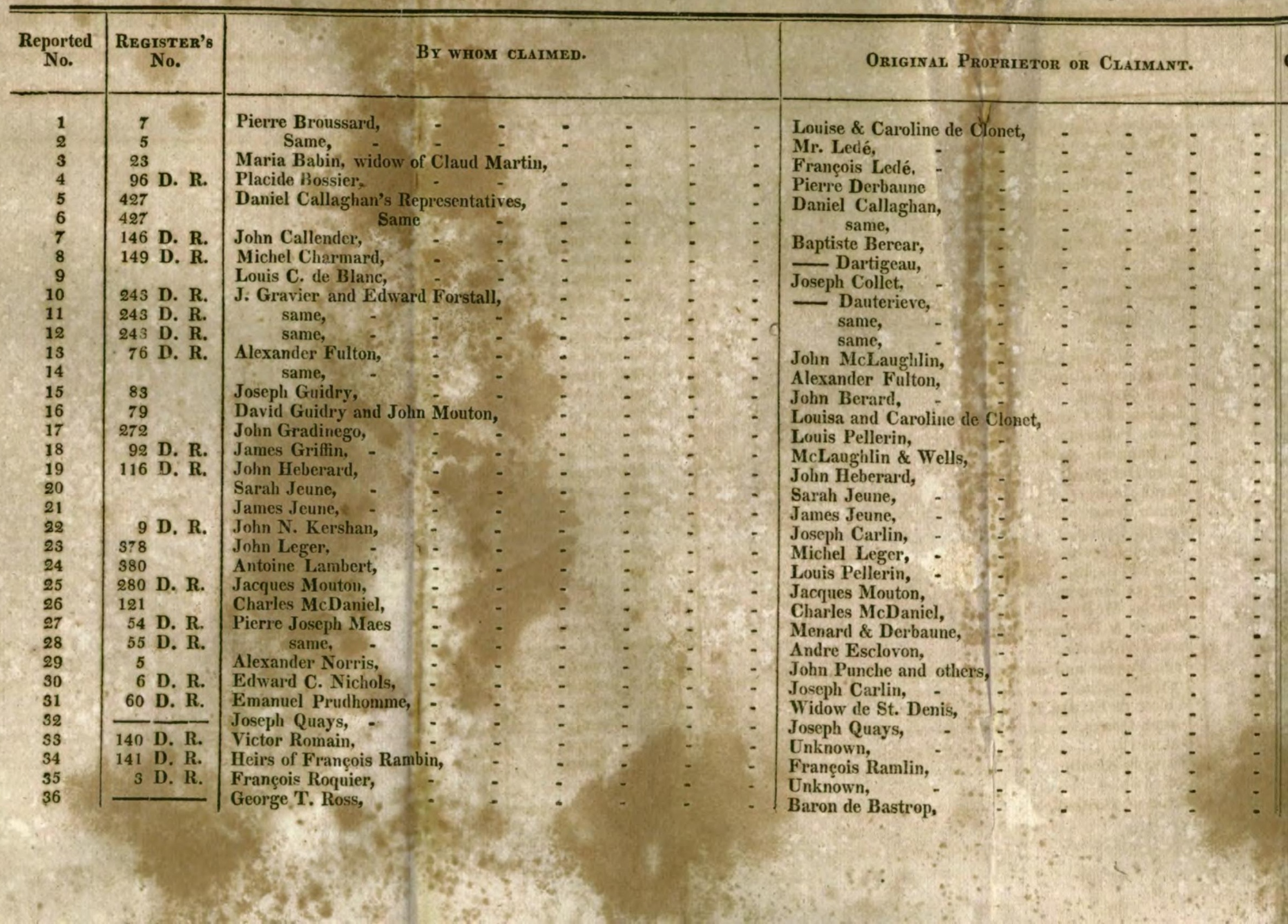

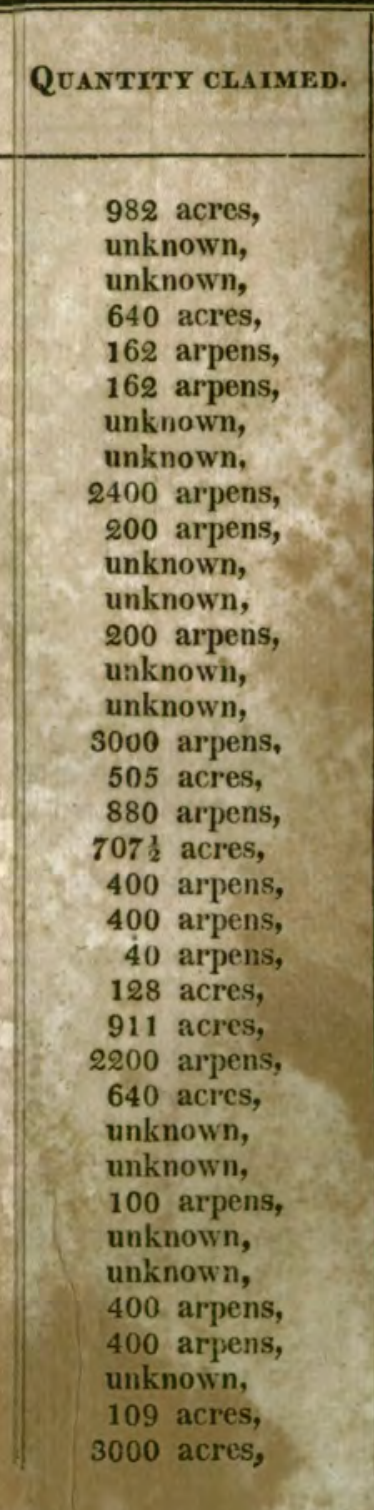
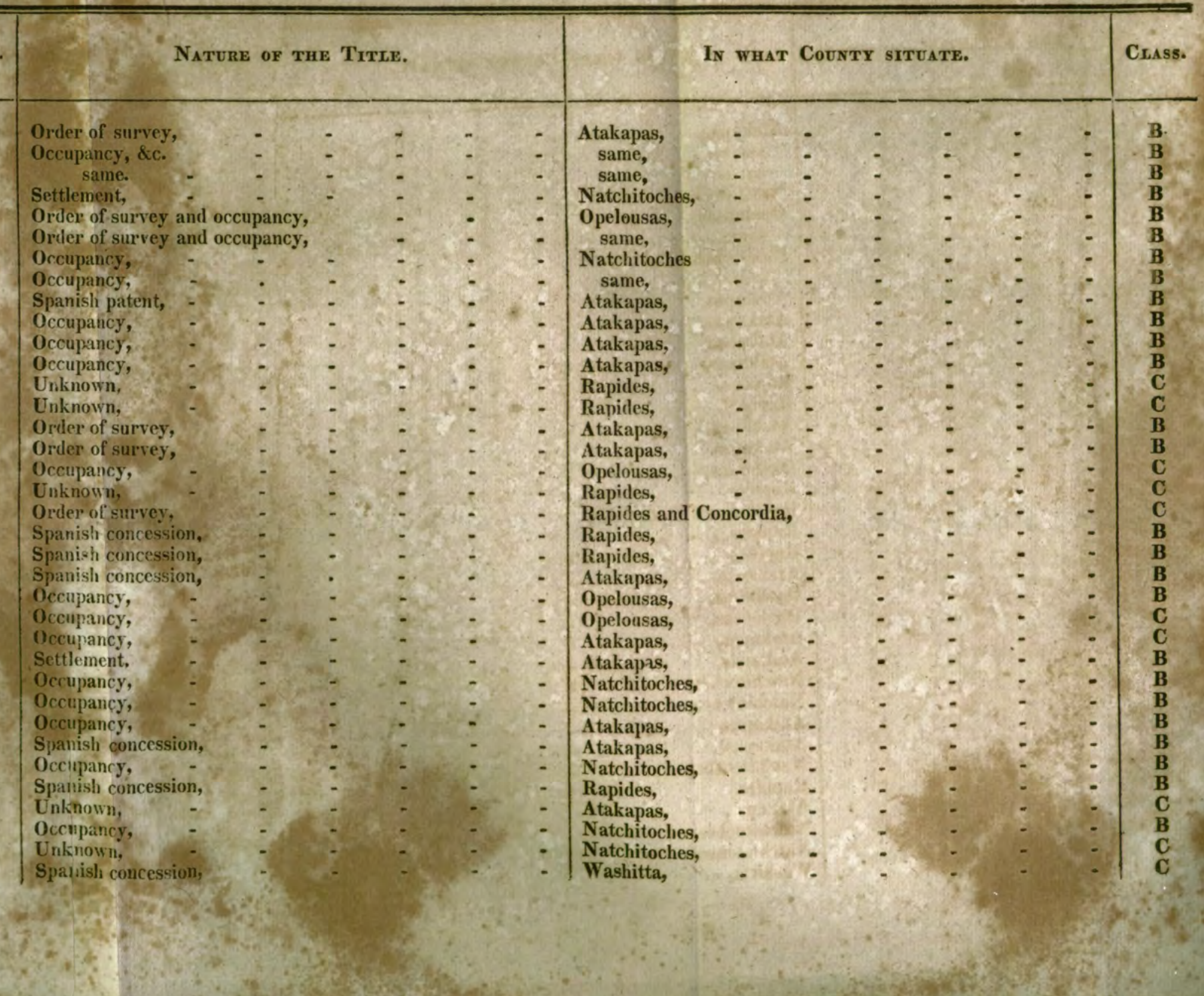
To the Honorable Josrat Mergs, Commissioner of the General Land Office in the Treasury Department.

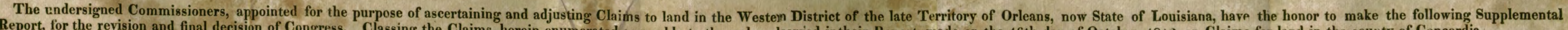

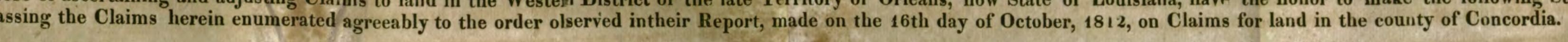

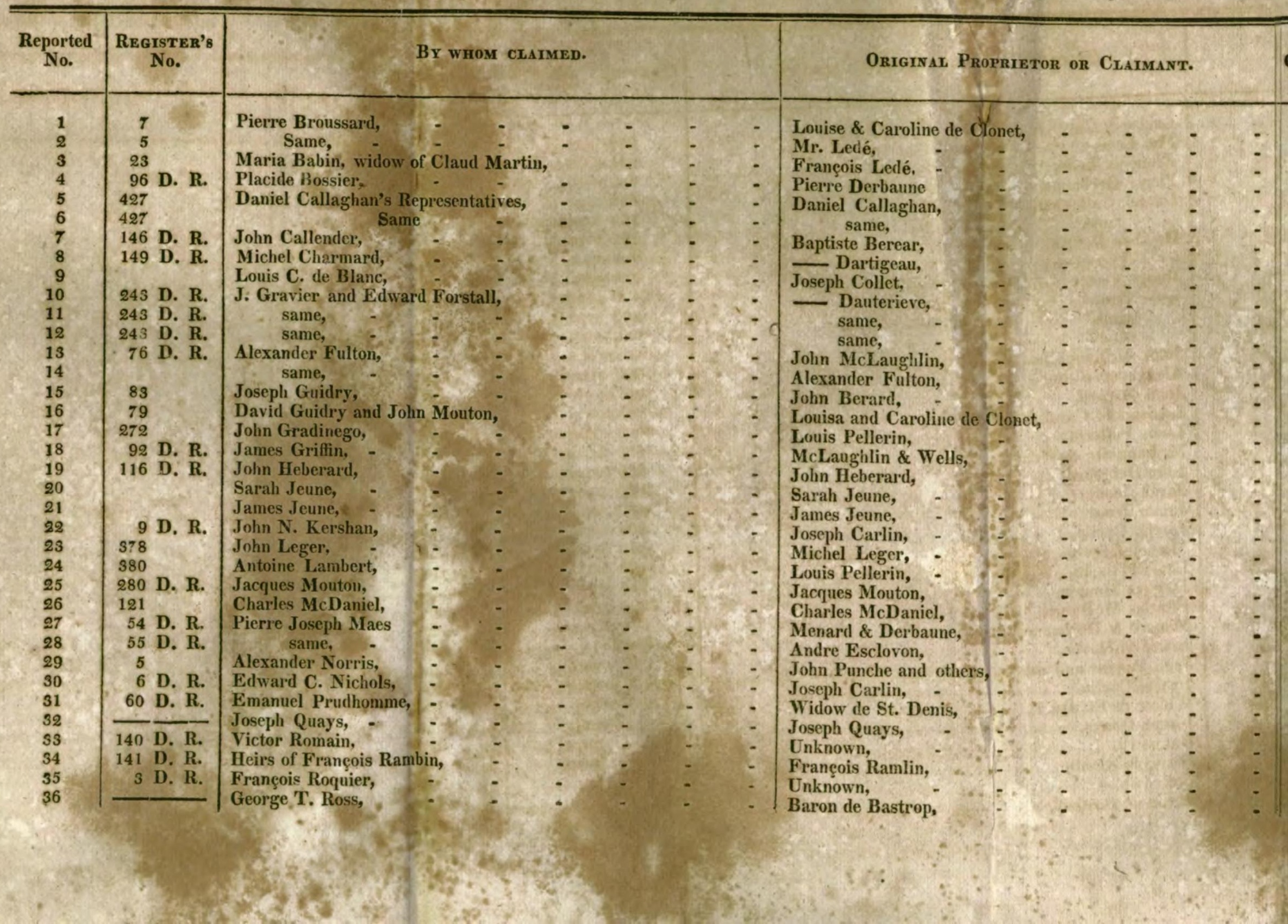

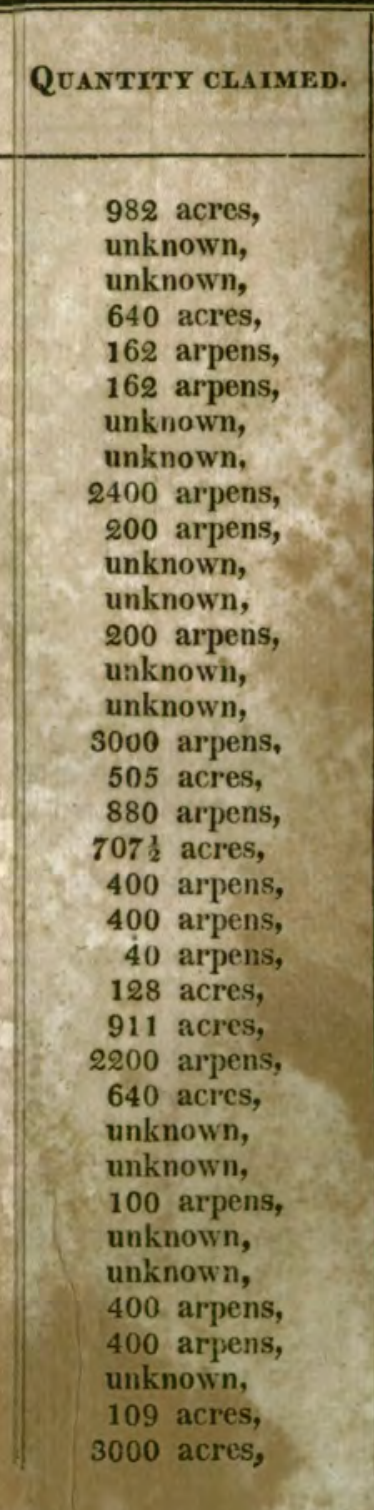
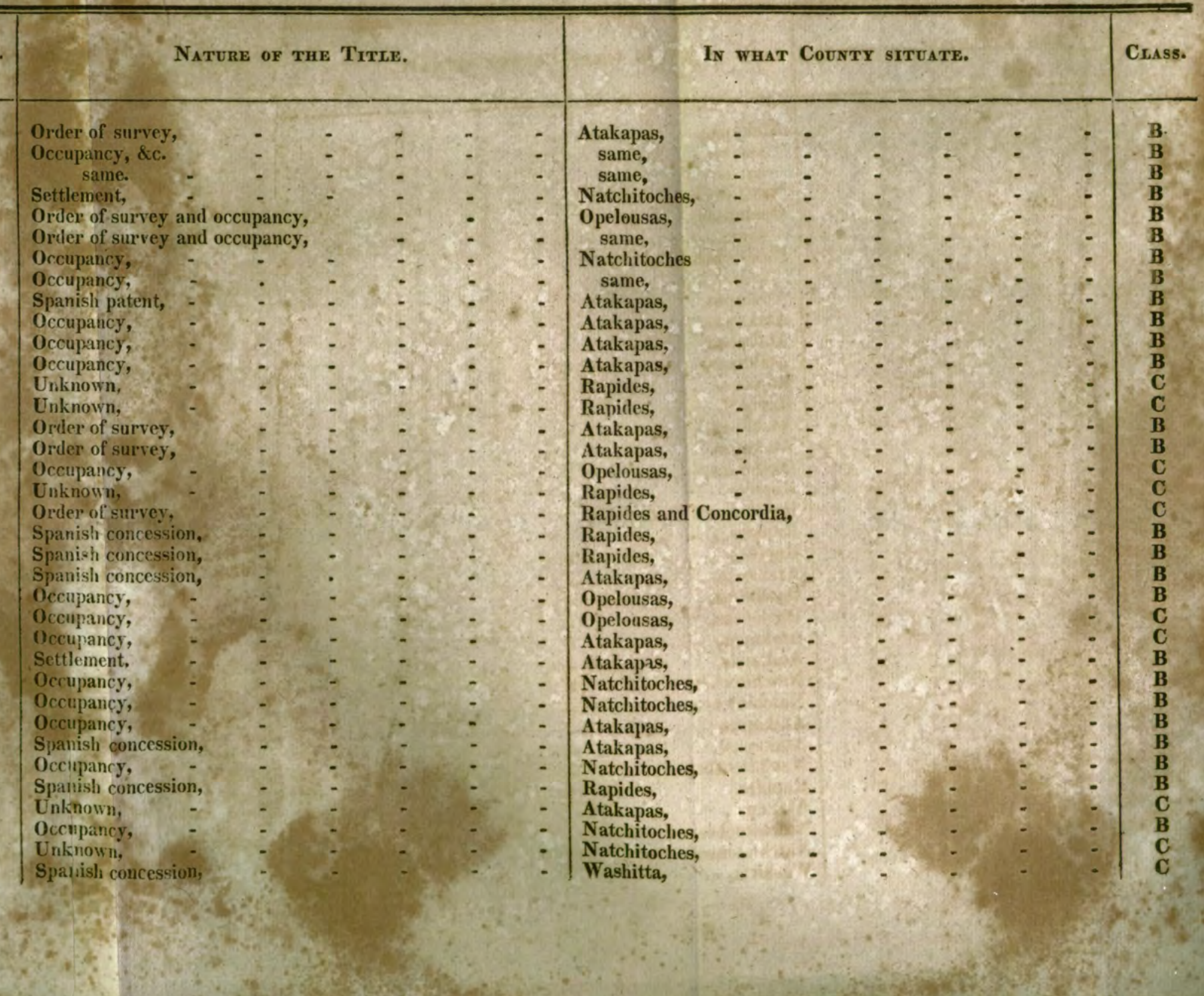
tives of Daniel Callaghan, to whom the land was conceded by the above order of survey of unquestionable authority.

No. 6. The legal representatives of Daniel Callaghan, deceased, claim 177 arpens of land, on the waters of the Bayou Bellevue, by virtue of an order of survey, in favor of said Callaghan, bearing date 24th September, 1789, for six arpens front, by the depth of forty arpens. The two first confirmations mentioned in the next preceding number, embraces equal quantities in each of the orders of survey, and the two claims being similarly circumstanced in other respects. This is likewise reported as one, which, in the opinion of the Commissioners, ought to be confirmed to the legal representatives of said Callaghan, for the above quantity of 177 arpens, remaining after deducting from the order of survey 15 arpens, embraced by certifcate B, No. 2276, to the inhabitants of Opelousas.

No. 7. John Callender, claims two lots of ground in the village of Natchitoches, of which the quantity is not set forth in the notice; and the title papers are said to be lost or mislaid. The notice of the claim is unaccompanied by any document of title. Gaspar Boudin, before the Board, the 15th June, 1812, hath deposed, " that the lands claimed, were inhabited about sixteen years ago, by one Baptiste Bercar, and that the same has been constantly inhabited ever since, by the said Bercar, and those claiming under him, until within the last two or three years of the present date. This claim is reported as one, which, in the opinion of the commissioners, ought to be confirmed on the occupancy; but for what quantity they are unable to say, because the claimant has adduced no document by which the quantity can be ascertained.

No. 8. Michel Chamard claims a lot of ground in the town of Natchitoches, of which the quantity is not set furth in the notice, fronting on Red River; bounded below by land of Francis Rouquier, senior, and above, by that of Francis Rouquier, juiior, and on the west side by the street held by purchase from Francis Rouquier, jun. Attorney for Mr. Dubois, and by cultivation. The notice of this claim is unaccompanied by any document of title. Francis Davion, before the Board, the 19th November, 1811, hath deposed, " that the said lot has been inhabited and cultivated, for more than thirty years ago, by one Mr. Dartigeau, and, every year since, by those claiming under him." The claimant having adduced no docu. ment of title, the commissioners can only report this as a claim which ought to be confirmed for the quantity, which may be found hereafter.

No. 9. Louis C. De Blanc. This claim is founded on a complete patent, granted by Governor Galvez, on the 5th January, 1777, to Joseph Collet, for 30 arpens front of land, on the west bank of the river Teche, in the county of Attakapas, with the depth of 80 arpens. The double depth being conceded, as appears from the papers, in consequence of the grantee having constructed his Indigo works, at the distance of 50 arpens from the front. On the abstract of complete patents, furnished for the use of the Board of Commissioners 
the one recorded in the name of Joseph Collet, and agreeing. as to date and other particulars, with the above, is entered as containing 2400 superficial arpens, which is the area that would be embraced by extending the lines of depth parallel to each other. The claimant has, however. presented with his patent, a plat of survey, in which the lines of depth are represented as diverging from each other, by an angle of 75 degrees and 30 minutes, including about 4200 arpens. The patent is unquestionably authentic, but the survey can add no dignity to the claim. It was made in 1805 , by Ferdinand V. Potier, unknown and unacknowledged by the surveying department, but who certifies that he was authorized to survey, by a commission from his excellency Governor Claiborne. When lands have been conceded by the Spanish government, for an equal depth on both sides of a water course, which, from the local situation, required that the lines of depth should close on one side, they have generally opened on the opposite. by which an area would be included on the two sides, equal to that which would be had by extending the lines of depth parallel to each other; and sometimes in grants lying wholly on one bank of a water course, where the calls are to adjoin other concessions above and below, the lines of depth have been made to diverge or converge, as the case may require, to correspond with the courses of the adjacent land. In the claim under consideration, howerer, it appears from the Requette of the claimant, that the land solieited, 30 arpens front, was bounded on one side by the land of Joseph Collet, and on the other side by the domain of the King. The order of survey requires, that the commandant should put the party in possession of the land as solicited; and the commandant, Chevalier De Clouet. certifies, that he had, on the 2sd of November, 1776, in virtue of the decree of the Governor General, established the party on the land petitioned for, thirty arpens front, on the west side of the Bayou Teche, with the depth of eighty arpens, at a place called the end of the "Fause Point," opposite the three Islands; bounded on one side by Mr. Collet, and on the other by the domain. The patent, or title in form, by Governor Galvez, dated 5th January, 1777 , is made conformably to the act giving possession by the commandant. No courses are specified as governing this concession, in any of the original documents of title. And the commissioners seeing no reason why the lines of depth should be run otherwise than parallel to each other, are of opinion, that this claim should be confirmed in such manner, as to confine the land claimed to that form, and the quantity which would thereby be included.

No. 10. Joh" Gravier and Edward Forstall, claim. five arpens front, by the depth of forty arpens on the Bayou Turtue, being part of a large tract granted to Mr. Danterieve. The notice of this claim is unaccompanied by any document of title. Andre Martin, before the Board, 20th August, 1811, hath deposed, "that the land claimed by Gravier and E. Forestall, of five arpens front by the depth of forty, on the east side of the Bayou Tortue, hath been inhabited and cultivated by the claimants, and those under whom 
they claim, for more than thirty years preceding this date, in regular succession." In this claim, it is incumbent on the claimants to produce the deed by which the title was transferred to them from Dantereive or his successors; and the claim is reported as oue, which, in the opinion of the commissioners, ought to be confirmed, on the production of the said deed or deeds, or an exemplification of them from record.

No. 11. John Gravier and Edward Forstall claim a tract of land of four arpens front, on the Bayou Tortue, and running in depth until it meets the forty arpens of depth from the Bayou Teche. This claim is unaccompanied by any document of title, but is set forth in the notice. to be a part of a grant of a league and a half front on both sides of the Bayou T'eche, to Mr. Danterieve.

Andre Martin, before the Board, 20th August, 1811, hath deposed, "That this tract, which is a part of the grant said to be given to Danterieve, hath been possessed by the claimants, and those nuder whom they claim, for more than forty years, and that the said land hath always been taxed for the public works, and the owners acknowledged as the proprietors."

It has not been attempted to prove that this claim has been settled, or cultivated. It has been possessed. as stated by the witness, by the several proprietors more than forty years, and acknowledged as their property, \&c. The claim is reported as one which, in the opinion of the Commissioners, ought to be confirmed for the quantity of land which may be found within the concession of $\mathbf{D}$ antereive, and for which the claimants may adduce satisfactory titles.

No. 12. John Gravier and Edward Forstall claim a tract of land of three arpens front on the Bayou Tortue, with the depth until it meets the forty arpens of depth from the Bayou Teche, being part of Mr. Danterieve's grant, of a league and a half front on both sides of the Bayou Teche. The notice of this claim is unaccompanied by any document of title.

Andre Martin before the Board, 20th August, 1811, hath deposed, "That the tract of land of three arpens front, on Bayou Tortue, with the depth to meet the forty arpens from the Bayou Teche, being part of the grant said to be given to Danterieve, claimed by J. Gravier and E. Forstall, hath been, by the claimants and those they claim under, possessed for more than forty consecutive yeors, and that they have always paid the public contributions to the present day."

This is claimed, also, as being within the concession to $D$ anterieve. It is, in all respects, similarly circumstanced with the claim next preceding, and, in the opinion of the Commissioners, ought to be confirmed for the quantity found from the survey to be within the grant, the claimants adducing satisfactory documents to establish their title.

No. 15. Alexander Fulton claims two hundred arpens of land situated in the county of Rapides, which is said to have been conceded by the Spanish Guvernment to John McLaughlin on the 8th June, 1798. Several deeds are referred to in the notice of this claim, as 
well as the concession to McLaughlin, none of which are found with the other papers of Mr. Fulton, and not appearing to have been enre gistered in the book kept by the Deputy Register of the district of Rapides, with whom the entry was made, and no evidence of occupancy having been adduced, the claim is presumed to have been withdrawn, and therefore, in the opinion of the Commissioners ought not to be confirmed.

No. 14. Alexander Fulton claims a tract of land on Bayou Trudeau, in the county of Rapides, by virtue of a grant from the Spanish Government, which he alleges was obtained about the year 1799, and lost or mislaid in the office of the Surveyor General, at New Orleans. The notice was filed with the Deputy Register at Rapides, and has been so chafed and defaced in transmitting the papers to Opelousas, that the quantity of land claimed cannot be seen. The claim is unsupported by any evidence; and therefore, in the opinion of the Commissioners, ought not to be confirmed.

No. 15. Joseph Guidry claims the quantity of land granted to John Berrard by order of survey, dated the 10th March, 1785, (except ten arpens front,) by virtue of a purchase made by the claimant from said Berrard. The notice of this claim is accompanied by the following documents, to wit: T'he requêtte of John Berrard, dated the 13 th January, 1785 , setting forth that, where his vacharie then was, he was bounded by the Coule Desnoix which crossed his land; and on account of the augmentation of his cattle, and the cattle of his children, prayed a concession of a continuation on the West side of said coule, for the quantity which should be ascertaired by the Surveyor. On the 15th February, 1785, the Chevalier De Clonet Commandant of Attakapas, certifies the verity of what is exposed by the petitioner. On the 10th March, 1785, Governor Miro orders the Commandant to establish the demandant, J. Bernard, on the forty arpens of land in depth, to be taken behind the vacharie mentioned in the writing on the other side, (this order being written on the same paper on which the requêtte is made,) and following the same courses of the racharie, that he may be provided with his title in form. On the 10th March, 1806, John Berrard, by deed in due form, sells to Joseph Guidery, the present claimant, the land conceded by the decree of the 10th March, 1785, with the exception of ten arpens front by the depth of forty arpens.

Andre Martin, before the Board, the 20th August, 1811, hath deposed : That the land in question, to wit : a tract of fifty arpens front on the first forty arpens West of the Vermillion, by an order of survey in favor of John Berrard, has been inhabited and cultivated on and before the 1st of October, 1800, and without intermission since, to the present date, the day on which his evidence was taken. The order of survey under which Mr. Guidery claims, is for no specific quantity. Berrard petitions for a continuation of the land he held on the West side of the river Vermillion, and the concession is for the land solicited. The claimant has had surveyed to him forty arpens front by the depth of forty arpens, on the back of a tract conceded to Berrard, one other tract conceded to Labbe, jun. and 
extending to a part of the back line of a tract conceded to Labbe Sen. To entitle the claimant to a confirmation of the claim as surveyed, it is necessary that he should adduce the deeds of sale, to esfablish that he was the proprietor of the lands granted to the two Labbes at the date of his requêtte, the 13th Jan. 1785. If it shall appear from the production of the deeds from the two Labbes. that Berrard was the proprietor of the tracts conceded to them at the date of his petition, for this continuation, the Board is of opinion that the claim ought to be confirmed for the quantity claimed, forty arpens front by the depth of forty arpens, leaving ten arpens front to Berrard But if, on the contrary, it shall appear from the deeds, that the lands were acquired from the Labbes subsequently to to Berrard's requêtte, the Board are of opinion that the confirmation should be confined to the quantity which may be immediately back of the tract conceded to Berrard.

No. 16. David Guidry and John Monton claim seventy-five arpens front by the depth of forty arpens, and such other depth as the original grant and conflicting claims will admit, lying on the river Teche, in the county of Attakapas, by virtue of a purchase from Alexander de Clouet to whose children the said land was granted. A deed of conveyence from Alexander de Clouet to the claimants, is the only documeet of title accompanying the notice of the claim.

Andre Martin, before the Board, the 16th January, 1812, hath deposed: That the land claimed was settled more than thirty years ago by the late Chevalier Alexander de Clouet, who continued to cultivate it for about twelve years, since which time it has been occupied and cultivated by Messrs. Martin Durald. Pierre Nezat. Joseph Pierre Nezat, August Nezat, Soleste Roy, Joseph Latiolet, Philip Dupletion, Pierre Boussard, Marcelle Pattin, Nicholas Thibeaudeau, Ceril Thibeaudeau, John Thibeandean. Pierre Guidry, Louis Guidry, Olevier Guidry, and others, by whom the occupancy and cultivation of the land, have been regularly and constantly maintained for the last thirty years, or more, and to the present date.

This claim is reported merely because the Commissioners have not been able to obtain information of its extent.

Several attempts have been made by the surveyors to survey the land, but all have failed, on account of an extensive swamp by which it is intersected. It is believed that the claim is wholly within the concession from the Spanish government to Louise and Carline De Clouet, which has been occupied and cultivated, as appears from the evidence of Andre Martin, more than twenty consecutive years before the transfer of Louisiana to the United States. The commissioners are therefore of opinion, that this claim ought to be confirm. ed for three thousand superficial arpens, equal to 2538.84 American acres, provided that so much shall be found within the limits of the concession, to Louise and Carline De Clonet, or for so much of the quantity short of the said three thousand arpens as shall be found by a correct survey, to be within the limits of said concession.

No. 17. The legal representatives of John Gradingo, claim 2707.92 acres of land at a place called "l'Isle a L'anglois," by purchase 
from Charles Vege, who bought from Francois Lemell, who purchased from Louis Pellerin the grantee. The notice is accompanied by a deed of sale from Louis Pellerin to Francois Lemell and Charles Vege dated 2 ist of A pril, 1780, for all the Island called L'anglois, with its appurtenances, as accorded to said Pellerin by the Spanish government, a deed of scle from Francois Lemell to Antoine Boisdore, dated 15th January, 1782, for the half of the Island called L'anglois, setting forth in the deed that the other balf had been given up to $\mathrm{Mr}$. Charles Vege, who by an arrangement, which appears to have been entered into before the commandant. dated 18 th February, 1782, stipulating for a divisional line, by which, after two years, the said Vege was to relinquish his claim to the upper or northern part of said Island, to said Antoine Boisdore, in exchange for the lower part; the said Vege retaining three arpens front in the said northern part, and reserving the privilege of removing, after the expiration of said two years, his houses, feuces, and fruit trees, from said northern part. A deed of sale. dated 27 th September, 1791, from Charles Vege to John Gradnigo, for bis right to said Island as he had it from Antoine Boisdore, with the exception of ten arpens front by the ordinary depth, which had been conveyed to Nicholas Rousseau and Mary J. Lemell. A platt of survey by an authorized surveyor, dated in 1806 , including the quantity claimed in the notice. In support of this claim, the following evidence has been adduced: John Baptiste Figuerant, aged sixty-nine years, before the Board 6th of August, 1811, hath deposed, " that, about twenty-three years ago, a man by the name of Vege, made an establishment on the land claimed; that the said Vege, about eighteen or twenty years ago, passed this land to John Gradnigo, in exchange for some other land ; from which time the said Gradnigo continued to inhabit and cultivate the said land, to the time of his death, which happened about two years ago. That he has frequently heard Chevalier De Clouet, the former commandant of the post of Attakapas and Opelousas say, that there was a complete patent from the Spanish government to Pellerin, former commandant of Opelousas, for said Island, and half a league around it. Being asked whether he was of opinion that it was intended that the half league should include any part of the woods, or be taken wholly in the Prairie, the deponent answers, that it is bis opinion, and he believes that it is the general understanding in the neighborhond, tiat the half league in depth should be taken wholly in the Prairie; that is, that the back line should in 10 part approacl, the woods of the Island, nearer than half a league. The deponent further saitb, that he never did see the title papers on which this claim is founded. but that he has heard others, as well as Mr. De Clouet, say, that there was a complete patent for it; and this appears to be the prevailing belief in the ueighborhood." Louis de la Houssay, by commission from the Board, before Woodson Wren, Justice of the Peace in Attakapas, 26th of November, 1811, hath deposed, in answer to the following interrogatories : Interrogation 1st. Do you know of a patent or any other description of tille, having issued by any Governor or other public 
functionary, under the French or Spanish government of Louisiana, to a Mr. Pellerin for a tract of land, embracing a body of woods called "l'Isle de L'angloise," in the county of Opelousas? Inter. 2. If you have any knowledge of the existence of such concession or grant, in whose hands have you seen it? Relate circumstantially any knowledge you may have of the tenor, \&c. of said concession. Answer to the 1st Interrogation. That about thirty years ago, as nearly as his recollection serves him, he was at Mr. Lemell's, where he found Mr. Louis Pellerin, the original proprietor of the land mentioned in the commission, and Mr. De Clouet the commandant. When Mr. Pellerin proposed to Mr. Lemell to purchase the abovementioned tract of land, which was done while at dinner, and immediately after the conveyance was passed by the commandant, he, this deponent, saw Mr. Pellerin deliver the original grant to Mr. Lemell, as soon as the conveyance or sale was signed and delivered, to which the deponent was a subscribing witness, but he did not examine the contents of said original grant, but was informed, and fully understood, that it comprehended the Island with the forty acres around it. The two following certificates given

2. by Martin Durand, have been filed in the claim, but do not appear to have been given under the solemnity of an oath.

\section{Translation.}

I, the undersigned, certify to have seen a concession of a place known by the name of "l'Isle a l'Anglois," situated in this post, granted to the deceased Mr. Pellerin, saying either half a league or forty arpens of Prairie all round said Island : on part of which Is. land, John Gradnigo inhabits, and where he has all his improvements. Given to be of use before whom it may appertain.

Opelousas, 17th Dec. 1805.

I, the undersigned, being questioned as to my knowledge of a concession for the Isle a l'Angluis, answer, that it was said at all times, that all that Island had been granted to Mr. Pellerin, deceased, with forty arpens of depth all round it; that I cannot affirm it as certainty, but $\mathrm{I}$ believe those titles to have been seen by me in the hands of the deceased Antoine Boisdore, or some others; what eonfirms me still more in the opinion that those titles did really exist, is, that in the transfer of that property from the deceased Frtancois Lemell to the deceased Antoine Boisilore, they are expressly mentioned and said to have been annexed to the said sale. This given to be of use where it may appertain.

Attakapas, August 9th, 1810.

Although the notice of the claim had been made for a specific quantity of land, conformable to the plat of survey, it has been contended by his representatives since his death, that the notice was so made without his fully understanding it; and that the claimant as well as his said representatives, and those from whom their title was 
derived, always contended that the Island was conceded by the Spanish government to Pellerin, with forty arpens of prairie in depth, all round said Island; and that having bought conformably to the concession to Pellerin, they are entitled to confirmation of their claim to that extent. The claimants, however, having failed to adduce the concession from the Spanish Government, or any record thereof, the commissioners have deemed it just to confine them to the quantity which they might hold under the act of Congress, allowing two thousand acres for occupancy ten consecutive years preceding the change of government. Considering the length of ocrupancy, as established by the most respectable testimony, and the probability that the concession, which appears to have been lost or mislaid, may have been for a larger quantity of land. the Board has decided, that, as two notices of claims had been regularly filed for said Island and its appendages, one under the claim of Vege. who beld the southern moiety, with an addition of three arpens front out of the northern, and one under Boisdore, who held the residue; that it would be correct to appropriate four thousand acres to the two claims. They have accordingly, by their certificates, No. 2234, confirmed to Antoine Lambert, who held under Boisdore the quantity of 1797 acres. To E. R. Lamorandier, by certificate No. 2232, 677 acres. To C. Voorhies, by certificate No. $2236,338 \frac{51}{100}$ acres; and to Louis Carrier, by certificate No. $2237,1178 \frac{4}{100}$ acres, making 4000 acres. The three last named persons holding under Gradnigo, who held under Vege, and the part which appears from the evidence to have been transferred to Nicholas Rousseau, leaving out of the claim of the heirs of Gradnigo, about five hundred and five acres, the title to which the claimants have failed to establish to the satisfaction of the commissioners, who are therefore of opinion it ought not to be confirmed.

No. 18. James Griffin claims 880 superficial arpens of land on Bayou Rapide, in the parish of Rapide, by purchase from Anselm Wells, brother and only heir of John Wells deceased. who purchased 480 arpens thereof, from James $M \cdot$ Laughlin, claiming the residue 400 arpens by a requette, in the name of the said John Wells, which is stated to bave been lost or mislaid, and on occupancy of both tracts which lie adjoining each other. The deed from M*Laughlin to John Wells, appears to have been executed before the proper Spanish rfficer, on the 26th May, 1801 ; and the evidence of occupancy being satisfactory as to that part of the land, the title to it has been confirmed by the Board of Commissioners, by their certificate B. No.942. The residue of the claim 400 arpens, ought not, in the opinion of the Commissioners, to be confirmed. The claimant having failed to establish the occupancy of that part of the land, or shew a valid title from the Spanish Government to himself or any former claimant.

No. 19. John Hebard has claimed 3200 superficial arpens of land on Black river, forty arpens front with the depth of forty arpens on the right bank of the river, in the county of Rapides, and a like 
front and depth on the left bank in the county of Concordia, near the junction of Washita with Black river. An order of survey conceding the land, as above described, dated 22d March, 1786, with the name of Estevan Miro, then Governor of Louisiana, subscribed to it, has been filed with the notice of this claim : from the appearance of this document, and comparing the signature with others of Governor Miro, the Commissioners have been induced to believe it a forgery, nevertheless the evidence introduced in the claim establishing very satisfactorily that the land in question has been inhabited and cultivated constantly, from the date of the concession more than 17 years before the delivery of Louisiana to the United States; and that, from the year 1791 or earlier, a public ferry has been kept at the place by the said Hebard, or those holding under him ; and as it appeared that the present claimants had paid fair prices for the land, and could not be considered as parties in the fraud, if any had been practised; the Commissioners have confirmed the claim to the full extent which might be claimed under occupancy for ten consecutive year's, to wit: two thousand acres, by their certificates, B. No. 1754 and 1755 , to Charles Miles and John Henry, each for one thousand acres, leaving out of the original claim about 1837 arpens, equal to about $707 \frac{1}{2}$ acres, the title for which, in the opinion of the Commissioners, ought not to be confirmed, unless, by a recurrence to records, the claimants may be enabled to establish that the concession is a genuine one.

No. 20. Sarah June claims 400 arpens of land on the Bayou Rapide, in the county of Rapide. The notice of this claim is accompanied by the petition of the claimant dated 6 th January, 1802. The certificate of the Syndic of the post of Rapide, Joseph Chevalier Poiret, dated 11th January, 1802, stating that the land solicited was of the Royal Domain. The decision of the Royal Fiscal, to whom the Requette was referred, dated at New Orleans the 15th November, 1802, followed by the decree of the Intendant General of the province, Juan Ventura Morales, in favor of the claimant, to uhich is annexed the plat of survey and certificate of Carlos Trudeau, then Surveyor General of the province, dated in $1 \$ 02$, representing a tract of four hundred arpens of land, fronting on the right bank of the Bayon Rapide, bounded on the one side by vacant land, and on the other side by the land of Joseph Quays, the surveys of which had been made, and a plat returned by his deputy, Hugh Coyle. The decree of Morales, late Intendant General, in this case differs from the form which was usual in granting orders of survey anterior to his administration of the Government of Louisiana, yet as the proceedings in the surveying department have given to it the effect of an order of survey, and as the survey of the land by an authorized surveyor is the best evidence of the claimant having been legally put in possession of the premises in question, although no evidence of actual occupancy has been adduced, the Commissioners are of opinion the claim ought to be confirmed, in conformity with the usages of the Spanish Governuent. 
No. 21. James June claims 400 arpens of land on the right bank of Bayou Rapide, bounded on one side by Jand of Joseph Quayes, and on the other side by the land of Michael Hootes. This claim being in all respects similar to the one reported under the next preceding number, is likewise reported as one which, in the opinion of the Commissioners, ought to be confirmed.

No. 22. John N. Kershaw, claims one arpen front, by the depth of forty arpens on the south side of Bayou Teche, in the vicinity of New Iberia being part of a complete title said to have been made to Juseph Carline, of ten arpens frout by the depth of forty arpens, on both sides of the said Bayou. The claimant having purchased from Francois Prevost six arpens front on each side of the Bayou, sold to Alexander Hebert six arpens front on the north side, and three arpens front on the opposite side to Mougenot and Myer, from whom the above one arpen front was purchased by William Collins, who sold it to the claimant, by deed bearing date the 10th October, 1805; which last mentioned deed of sale accompanies the notice, describing the said one arpen front, to be bounded on the lower side by land of Mougenot, and above by that of Williain Smith. No other docu. ment accompanies the notice, and no proof of occupancy. From the documents filed in the claim of Edward C. Nichols, which will be found reported under No. 30 , to which the claimant refers in his notice, the Commissioners are of opinion that this claim is a part of a tract conceded by the Spanish Government to Joseph Carline, at an early date and therefore, ought to be confirmed.

No. 23. John Leger claims 128 acres of land, in or adjacent to the Prairie Grand Coteaux, by virtue of settlement by Michel Leger, from whom he derives his claim. The notice of this claim is unaccompanied by any document of title, except a plat of survey, dated in 1806. The claimant sets forth that the claim is situate adjoining to, and at the back of, a tract which was conceded to Paul Boutin, who sold to Michel Leger, under whom the claimant holds. That when Michel Leger settled, he supposed his establishment to be on the tract conceled to Boutin, and it was not until he had the land surveyed about twelve months ago, (say in Dec. 1806, he discovered his mistake.) John Teller, before the Board, the 23d Nov, i808, hath deposed, "that the tract of land claimed, was settled upwards of 12 years ago by Michel Leger, who purchased it from Paul Boutin, the original grantee, and that it has been inhabited and cultivated ever since; that the present claimant was residing on it in the year 1803, and that he is a man above the age of 21 years, and the head of a family." The claim being for a small quantity of land, to cover the improvements which the claimant and Michel Leger, had erronenusly made on the public domain. and it not appearing that the claimant ever had any grant of land from the Spanish Government in his own name, the Commissioners are of opinion that the claim ought to be confirmed, and report it accordingly.

No. 24. Antoine Lambert, claims $=2707 \frac{92}{100}$ acres of land in the quarter de Pleasance, county of Opelousas, by purchase made by 
him at the vendue of the estate of the deceased Antoine Boisdore. In this claim, Jacques Dupre, aged forty one years, examined under oath before the Board, deposeth, that he is well acquainted with the land in question, being in the neighborhood of his nativity; that he recollects perfectly when $\mathrm{Mr}$. Charles Veger, a former proprietor, was residing on the said land, at the northern extremity of the said island, more than twenty years past; that the said Veger continued to inhabit and cultivate the said north end of the island for several years, and until, by an exchange with Mr. Antoine Boisdore, the said Veger transfer red his right to $\mathrm{Mr}$. Boisdore; since which time, the land in question has been constantly respected as the property of Mr. Boisdore, and the persons who have claimed under him to the present day, 16 th May. 1814. The Commissioners, refer to the claim of the representative of John Grarienigo, reported under No. 17, by which it will be seen that this claim is for part of the tract said to have been conceded to Louis Pellerin; that much of the evidence in Gradenigo's claim applies equally to this; that the Commissioners have issued their certificate to this claimant in confirmation of bis title to 1797 acres, in consequence of the long uninterrupted occupancy, and that the residue of the claim, being abont 911 acres, is unsupported by any legal document or evidence which might entitle it to confirmation, and therefore, in the opinion of the Commissioners, ought not to be confirmed.

Jacques Moulon, claims 55 arpens of land front, on both sides of the Bayou Teche, the land on the west side being claimed by virtue of a purchase of 80 arpens front, from Nicholas Forstall, that on the east or left bank claimed under occupancy ; the following testimony has been adduced in support of the claim :

John B. Senet, before John Thompson, Esq. late Register, 13th December, 1808, hath deposed, "That about three or four and twenty years ago, the tract of land claimed was settled by John Louis Drouet, for the present claimant; that he resided on the same for 13 or 14 years, and cultivated it; that when he left it, he put a family of free negroes thereon ; that the said claimant, not being satisfied with the free negroes residing on the land, sent up a mulatto man, slave to the claimant, to occupy the same, who resided thereon about six years, when he died; that, during the time he resided on said land, he cultivated it and took care of the cattle which the claimant had on that side of the Bayou ; that the said land has always been known in the neighborhood; for the property of the said claimant, and that the deponent would have applied for it himself, if he had not believed it to be his property ; that the said claimant, on the 20th December. 1803, was an old man and the head of a family, and that he resided in New-Orleans at that time; that he has always paid taxes for the same land, as the receipt which this deponent has in his possession will shew.

Andrew Martin, before the Board, 4th October, 1811, hath deposed "That the land claimed has, since the purchase made by said Moulon, and for more than twenty years, been known as the property of the claimant, who possessed it and paid the taxes for the same from the above said time. 
Louis Drouet, on the 11th November, 1812, before Judge Lislet, of New Orleans, under a commission from the Board, after being sworn and examined in this claim, hath answered as follows : Inter. 1 . Do you know the situation of the land in question, and where is it situated? Ans. That the land in question is situate in the lower part of the Bayou Teche, having 55 arpens front on both sides of the said Bayou, with the usual depth. Inter. 2. Was the said land inhabited and cultivated on the left side of the Bayou Teche, on the 20th day of December, 1803, if by whom, and how long previous to that time ? Ans. The said land has been permanently inhabited and cultivated on both sides of the said Bayou, by the negroes of James Moulon, of the city of New-Orleans, under the direction of either him, this deponent, or his brother, the late Nicholas Drouet, or of his brother-in-law, the late John B. Senet, or by some person employed by the said James Moulon, since twenty years and upwards, and until the year 1805, and even later. Inter. 3. Relate all you know with respect to said land ? Ans. He has stated all he knows with respeet to said land, but thinks it necessary to declare, that James and Nicholas Drouet, his brothers, as well as John B. Senet, his brother-in-law, are all dead. A receipt given to John B. Senet, by Wm. Moore, as collector of taxes for James White, Parish Judge of Attakapas, dated 19 th Feb. 1808, for nine dollars and sixty two cents, for the taxes due by Jacques Moulon, for the year 1807, without describing the property on which said taxes were paid, is filed with the notice, and is believed to be the receipt to which the said Senet has referred, in his evidence taken by the late Register. The claim for so much of the land as lies on the right bank of the Teche, has been confirmed to the claimant, under a complete Spanish patent, made in favor of Nicholas Forstall, by the certificate of the Commissioners, marked A. No. 1575. From the general terms in which the testimeny of John B. Senet is expressed, the Commissioners are in a great degree left to conjecture bis meaning. Nor is the evidence of Drouet, taken before the Parish Judge for the city of New-Orleans, as perspicuous as could be wished ; they both speak generally of the land on both sides of the Teche. The Board is induced to believe that the habitation of the persons who superintended for the claimant, must have been on that side of the Teche. to which his title was unquestionable, to wit: on the right bank, and if the negroes of the claimant, who had charge of his cattle, did sometimes cultivate on the Royal Domain, on the left bank, and should even sometimes have resided on that side, the Board are of opinion that this would not have constituted a title under the Spanish Government.

That it is not such a claim as was contemplated by Congress, in granting a right from ten consecutive years possession, by the ed section of the act of the $3 d$ March, 1807, and therefore ought not to be confirmed.

No. 26. Charles McDaniel claims whatever the Board may grant, not exceeding 640 acres, by virtue of a right of settlement within a survey made by order of William Biggs, on the Eastwardly side of the River Teche, about a mile above its confluence with the River Chafalja. 
The notice of this claim is unaccompanied by any document of title. John Henry, before the Board, the 6th May, 1812, hath deposed: "That, sixteen years ago, this deponent was employed by the claimant, to plough for him on the land claimed ; that from the appearance of the buildings and other improvements on the land. he supposes the claimant may have inhabited it for several years preceding the date at which the deponent was employed, as aforesaid ; and that the land in question has been constantly inliabited and cultivated ever since, until within the last two years." The land claimed, is acknowledged to be within the claim of William Biggs, reported No. 16, Attakapas claims, and conflicting with a claim for land occupied by permission of the proper Spanish authority, is reported for the consideration of Congress. The question of right, between the adverse claimants, ought to be left to the adjudication of the Courts of Justice. The Commissioners cannot judge as to the credibility of the witnesses, in the two claims, and report this as a claim, which, in their opinion, ought also to be confirmed.

No. 27. Pierre Joseph Maes, claims a tract of land in the Bourg of Natchitoches, containing such front as may be found between the land occupied by Charles Pavie, in the said Bourg, and the land sold by the claimant to a Mr. John Nancarrou, with such depth as may be found, suppose forty arpens, by virtue of his right as heir, and by intermarriage with Madam Widow Mary David, the daughter of Pierre Dartigeau, the said Dartigeau having purchased the same of a certain Mr. Marmillion, who held it by purchase at the sale of the estate of Pierre Derbaune, who purchased it from Louis Menard, who purchased from Matthew Monet, and Barbet Rachel, who purchased from Francois Mezier, who purchased from Gaspard Derbaune. The notice of this claim is acconipanied by the following deeds of sale : 1st. Deed of sale, from Mr. Mermillon to Pierre Dartigeau, dated 22d August, 1776, for two lots of ground, (suppose in the village of Natchitoches,) the lot formerly purchased from Pierre Derbaune, and another lot adjacent to the above, which the seller purchased at the sale of the estate of Louis Menard, and two lots composed of 14 toises and 11 feet front on the road, bounded South by Sorrel, a Blacksmith; North by Andre Esclovan; East by the River; and West by the hills. $2 d$. Deed of sale, from Louis Mienard to Pierre Derbaune, dated the 2d October, 1758, for one acre seven toises and five feet, on the ordinary depth, with the building, \&c. on the land, for the consideration of one thousand livres, and one cow and calf; sale executed in Natchitoches, and understood, from an endorsement on the back, to be for a lot in the town, since belonging to Marmilion. 3d. Sale, dated 28th December, 1756, from Matthew Monet and wife, to Louis Menard, for a lot, with the building and improvements, supposed to be the same sold by Menard to Derbaune. 4th. Sale, from De Mezier, dated 26th January, 1756, to Monet, for a house and lot, and plantation, on the other side of the River, such as he bought from Gaspard Derbaune. 5th. Sale, dated 2sd March, 1753, from Gaspard Derbaune, to Mr. De Mezier, for the land from Monet's fence to his ancient boundary : 
Antoine Prudhomme, before the Board, the 20th November, 1811, hath deposed-_. That tie land claimed has been constantly, and without intermission, inhabited and cultivated for thirty years, preceding the present date." The Commissioners not having been able to ascertain the quantity of land in this claim, repert, as one which, in their opinion, ought to be confirmed, for the quantity which may be found within the boundaries set forth in the deeds of sale, filed in the claim.

No. 28. Pierre Joseph Maes, claims a tract of land in the Post of Natchitoches, bounded on the North by land of Rambin, and on the South by land then occupied by Pierre Bartigeau, by virtue of a purchase from Pierre Gagnor, the 7th April, 1786, who purchased the same at the sale of the estate of the deceased Andre Escloven. The notice of this claim is accompanied by a deed of sale from Pierre Gagnor to Pierre Joseph Maes, dated 17th April, 1786, for a house in the village of Natchitoches, with a lot fronting on the woods. Bounded on the one side by Mr. Rambin, and on the other by Mr. Dartigeau, such as he bought it at the sale of the estate of the deceased Andre Escloven. - No other document of title has been adduced. Antoine I'rudhomme, before the Board, the - November, 1811, hath deposed : "That the said lot has been inhabited and cultivated, by one Andre Escloven, and those claiming under him for more than thirty consecutive years." 'The Commissioners are of opinion that this claim ought to be confirmed, for the quantity of land which, from survey, may be found within the boundaries of the lot, as described in the above deeds of sale filed in the claim.

No. 29. The legal representatives of Alexander Norris, claim two and a half arpens of land, lying in the town of New Iberia, on the Bayou Teche, by purchase from John Punche and Solisby Louis Robeau, who sold to William Collins and Kershaw, the latter of whom sold his part to said Collins, from whom the claimant purchased. The deeds of sale above referred to, except that of Punche to Robeau, accompany the notice, all of them except the last having been executed before the Spanish authorities. whose duty, it is believed, required that they should be satisfied of the right of the seller, ought to be regarded as sufficient evidence of title. The claim, therefore, although no evidence of occupancy has been adduced, ought, in the opinion of the Commissioners, to be confirmed.

No. so. Edward C. Nichols, claims seven arpens front, by the depth of forty arpens, on the West side of the Bayou Teche, and seven arpens front on the East side of said Bayou, opposite the above. of which four arpens extend to half the depth of the woods, and the other three to the whole depth of the woods, by virtue of two purchases, one from Francois Cesar Boutte, acting for Philip Boutte, for four arpens front on both sides of the Bayou, with the depth of forty arpens, on the West side, and half the depth of the woods on the East aide of said Bayou. The other from J. N. Kershaw and wife, for three arpens front, by forty in depth on the West, and a like front on the East side, and extending to the depth of the woods. Philip Boutte, purchased from Joseph Carlin, who is said to be the grantee. Ker. 
shaw and wife purchased from Francois Provost, who purchased from the said Carlin. The deeds of sale, establishing the transfers above mentioned, accompany the notice. An affidavit is found among the papers in this claim, without date, but known to be in the hand writing of Mr. Cocke, late a member of the board of Commissioners, subscribed by Edward C. Nichols, the claimant, in the following words : "Edward C. Nichols, being first sworn, in the presence of the Board, says, "that he has good reason to believe. and actually does believe, that the complete title mentioned in his notice, made in favor of Joseph Carline, and upon which his title is founded, is lost, so that it will not be in his power to obtain the said original grant. No evidence of occupancy has been adduced.

The Commissioners are of opinion that the deeds, all of which were executed before the change of Goverument, before the proper Spanish authorities, and duly recorded, except those from Boutte and Kershaw, to Nichols, which were executerl since the change of Government, before L. C. Deblane, Justice of the Peace, ought to be taken as sufficiont evidence of title, and that the claim otght to be confirmed to the legal representative of the deceased claimant, Edward C. Nichols.

No. 31. Emanuel Prudhomme claims a tract of land on the left side of the Red River, descending, containing about six arpens front, depth not mentioned, by virtue of a purchase from Madam Widow St. Denis, in 1788. The notice is accompanied by the deed of sale from the Widow St. Denis, to Emanuel Prudhomme, dated 11th March, 1788, passed before Louis C. de Blanc, Commandant of Natchitoches, "for the land which the said widow has oecupied to this moment;" situate on the other side of the Rirer, bounded below by the Bayou de la Mobile, and above by land of Pierre Badin, such as it is, in exchange for another tract of land describerl in the deed. Antoine Prudhomme, before the Board, on the 20th November, 1811, hath deposed, "That the said land, situate on the left side of Red River, was inhabited in the year 1788, by said St. Denis, and has been by those holding under her without intermission, to the present date." The Commissioners consider the title to the land sufficiently established by the evidence of Antoine Prudhomme, and the deed of sale, but not having been able to ascertain the quantity to which the claimant is entitled, report the claim, as one, which, in their opinion, ought to be confirmed, for so much as may be found, from survey, to be within its proper limits.

No. 32. Joseph Quays claims 400 arpens of land, in the county of Rapide, on the Bayou Rapide, by virtue of a concession from the Spanish Government, bearing date 15th November, 1802, and plat of survey by the late Surveyor General Carlos Trudeau, dated, also, in 1802, which tract is bounded on one side by the claim of Sarah June, and on the other by that of James June. This claim, being in all respects similar to those of Sarah June and James June, reported under Nos. 20 and 21, is likewise reported, as one, which, in the opinion of the Commissioners, ought to be confirmed.

No. SS. Victor Romaine claims ten arpens of land front, by the deptls of forty arpens, on the East side of the Bayou Teche, with a 
right in three acres on the West side of said Bayou, by purchase from Louis Judice, who purchased it from Mr. Danterieve, to whom it was conceded. A plat of survey, dated in 1806, and an acknowledgment by Louis Judice, dated 24th December, 1806, to have sold twelve arpens front on Bayou Teche, by the depth of forty arpens to Victor Romaine, bounded on one side by Forstall, and on the other by the seller, are the only documents filed in the claim. No proof of occupancy having been adduced, and the documents of title not being sufticient to establish the claim, or to shew that it is part of a tract conceded by the Spanish Government, the Commissioners are under the necessity of reporting it as a claim, which, in their opinion, ought not to be confirmed.

No. 34. The heirs of Francois Rambin claim a lot of land in the post of Natchitoches, fronting on the river, and running for depth to the street, bounded above by the land of Andre Rambin, and below by that of Mr. Maes, by virtue of settleuient and cultivation. The notice is unaccompanied by any document of title. Francois Perault, before the board, the 14 th December. 1811, hath deposed, "That the said lot has been inhabited and cultivated for more than forty years, immediately preceding this date." Barthelemy Rachel, on the 24th Jannary, 1812, hath deposed, "That the said lot has been inhabited and cultivated for more than thirty consecutive years, immediately preceding this date. The witnesses have not stated by whom the lot was occupied. The Commissioners take it for granted, it must have been the deceased Francois Rambin, or his representative, or some person for their use. The validity of the title being therefore established by the evidence, the commissioners are of opinion the claim ought to be confirmed for the quantity which may be found within the known limits of the lot by survey.

No. 35. Heirs of Francois Rouquier claim 109 acres of land on the right bank of Red River, in a triangular form, bounded on the upper side by land claimed by Antoine Vascoen, and on the lower side by land of the claimant's. His claim being unsupported by any evidence of title, is reported as one which in the opinion of the commissioner's ought not to be confirmed.

No. 36. George T. Ross claims three thousand acres of land in the county of Washita, by virtue of a purchase from Nicholas Meriwether, attorney for Charles Lynch, who claimed under a concession of twelve leagues square of land, from the King of Spain to the Baron de Bastrop. The notice of this claim is accompanied by an informal plat of survey, without date, shewing the quantity of the claim, and its situation on the left bank of the Bayou Bartelemy. The deed of sale from said Meriwether, as the attoiney of Clarles Lynch, of the State of Kentucky, is written on the same paper containing the plat of survey, and bears date 19th July, 1805 . No other document of title, and no proof of occupancy, has been adduced in support of the claim ; it is therefore reported as one which in the opinion of the Com missioners ought not to be confirmed. 
No. 37. James Robertson claims 640 acres of land on the Mississippi river, in the County of Concordia, by virtue of settlement and cultivation, and by deed of conveyance from Philip Love, dated 29th January, 1806. The deed of sale above mentioned, is the only document of title accompanying the notice of the claim. John Maylone, 1st March, 1806, hath deposed, "That, in the spring of the year 1804, he was on the land claimed, for the first time; that he knows that, in the month of September, 1803, Philip Love, with several negroes, were making an improvement on said land; that, in the spring following, they had built a small cabin, and cleared about two acres of land, which was planted in corn and pumpkins, but not cultivated during that season, and the land has remained uninhabited ever since." Isaac Burley, before Richard Cocke, Esq. late Land ComEx missioner, 7 th March, 1809, Concordia, hath deposed, "That, on the 20th December, 1803. Philip Love, under whom the present claimant claims, was over 21 year's of age. But his place of residence at that time, is unknown to the deponent." George Ritchie, on the 5th October, 1810, hath deposed, "that, in the month of September, in the year 1803, he was on the tract of land situate on the right bank of the Mississippi river, about nine miles above the mouth of Cole's Creek, then claimed by Philip Love, and since transferred, as this deponent has understood, to James Robertson; that, at that time, the said Love was residing on the premises in question; had two or more cabins on it, and a small piece of ground cleared, and under cultivation, in cabbage and other vegetables, and that he, the said Love, did continue to inhabit and cultivate said land, to the end of the year 180s, and for some years afterwards, and that he does not know or believe, that the said Love did hold or claim any other land in the Territory." Elijah Cushing, hath deposed, "that, in the month of November or December, 1803, this deponent was on the land claimed, where he found Philip Love superintending several negroes, who were employel in cutting timber for market, for the benefit of Major Benjamin Kitchen, at that time an inhabitant of the Mississippi Territory, and that he does not believe that the said Love had at that time any intention of cultivating or claiming the land." The evidence of Elijah Cushing makes it appear, that Philip Love, from whom James Robertson derives his claim, was on the land only as the agent of Benjamin Kitchen, and that Love bad no intention of cultivating or claiming the land at the time he was on it in November or December, 1803; and no evidence having been adduced to establish that Love had any permission from the proper authority, to occupy the land, the Commissioners are of opinion, the claim ought not to be confirmed, and veport it accordingly. It is nnderstood, that the claim of Benjamin Kitchen, derived from Wm. Turner, and confirmed by the Commissioners certificate B, No. $155 \mathrm{~s}$, is for the same, or part of the same land.

No. 38. John Bte. Senet, as natural guardian for his son, Joseph Senet, claims 640 acres of land on the waters of Bayou Teche, County of Attakapas, by virtue of settlement made previous to the yeat

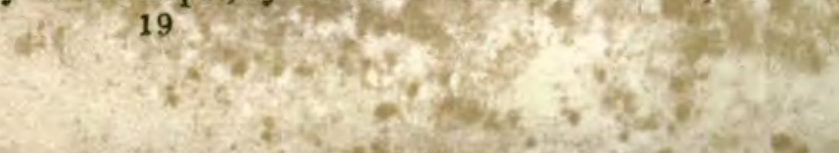


1805. The notice of this claim is unaccompanied by any document of title. Charles McDaniel, before John Thompson Esq. late Register, 25th January, 1809, hath deposed, * that, for ten years past, the claimant, John Bte. Senet, hath cultivated the land claimed, but this deponent doth not know that any person except Indians hath ever resided on the same." Jacob Garrard, before Richard Cocke, Esq. late one of the members of the board, on the 22d January, 1809, hath deposed, " that, about 8 or 9 years ago, the claimant settled upon a tract of land opposite to the land claimed, where he has resided ever since, and cultivated every year as well the tract claimed, as the one on which he resided ; that, about 6 or 7 years ago, the claimant had a cabin on the land claimed, in which the negroes of the claimant then resided, but how long they had resided there, the deponent cannot say." This claim does not come within the intendment of the act of Congress, granting donations from the right of settlement, and, in the opinion of the Board, ought not to be confirmed.

No. 39. Maria Simien, a free negress, claims two arpens of land in front, with the depth of forty arpens in the Big Woods, by virtue of inheritance from her son, who purchased it from the widow Rideau. The notice of this claim is accompanied by a deed of sale from the widow Rideau, to Antoine Simien, dated in 1801, and a plat of survey of the land, by Luke Collins, deputy surveyor under the Spanish Grovernment, dated 31 st December, 1800, the said surveyor setting forth in his process verbal, that it is part of a tract of twelve arpens front, by the depth of forty arpens, granted to Michel Brignal, the 5 th of March. 1778. The title of Brignal has been confirmed by the Beard, by certificate A, No. 1918, of which this claim is believed to be a part, and, therefore, needs no further confirmation.

No. 40. Francois Saubadon. claims forty arpens front of land, by the depth of forty arpens on the right bank of the Mississippi river, between Red River and the Chafalia, by virtue of his petition, and the consequent decree of Governor Miro. The claimant having filed with the notice of his claim the order of survey by Governor Niro, dated 17 th February, 1785 , on which the claim is founded, and which being for the quantity of 12 arpens front, by the depth of forty arpens only, the claim for that quantity has been contirmed by the certificate of the Commissioners, marked B. No. 1037. The residue of the claim is therefore reported as one which, in the opinion of the Commissioners, ought not to be confirmed.

Nn. 41. John Sibley claims, under Paul Boit Laffitte, a tract of land containing about six and an half arpens more or less, fronting Red River with the usual depth of forty arpens back; , bounded southerly, or down the river, by Louis St. Prie or Pierre Benoist, and northerly, or up the river, by the mouth of a large Bayou called Coochenahaw.

The notice of this claim is accompanied by a certified copy of a deed of sale from Paul Boit Laffitte to John Sibley, dated 12th March, 1807 , of which the following is a translation : "Before Marcell Soto commandant civil and military at Bayou Pierre, in the province of Texas, on the 12th March 1807, Boit Laffitte, inhabitant of Bayou 
Pierre, declares to have sold to John Sibley a tract of land in the vicinity of Grand Ecor; bounded above by the river and Benoist Montanery until it strikes the Bayou Conchana." John Ris, aged about 53 years, before the Board, 18th February, 1813, hath deposed, "That the land has been inhabited and cultivated for more than thirty consecutive years preceding this date ;" no other evidence of title has been adduced in support to the claim. The second section of the act of Congress of the 3d of March, 1807, on which this claim is founded, restricts the benefit granted by that section to the person in possession or the legal Representative of the person in possession of the land on the 20th day of December, 1808. It does not appear from the evidence adduced, that Paul Boit Laffitte, was in possession of the land on the 20th December, 1803, and the board is disposed to believe he was not so in possession, because it has been suggested by Major E. Lamcorandier, who is acquainted with Laffitte, that he has been many years an inhabitant of the Bayou Pierre settlement, where he was residing at the time of executing the sale; and because no document of title has been adduced to establish such possession. Even if it had been ascertained that he was the person in possession of the land aforesaid, the Commissioners would not be inclined to recognize as legal and valid, a deed of sale executed before a person subscribing himself " Commandant for the District of Bayou Pierre in the Province of Texas," in the year 1807 . First, because they have no means of knowing that he ever held such an office, and secondly, because it is contended that that settlement is within the proper limits of Louisiana, as cerled by the French Republic to the United States. The present claimant cannot therefore be considered the legal Representative of Laftitte. For these reasons, the Commissioners are of opinion the claim ought not to be confirmed. No. 42. John Sibley claims under John Horn, $195 \frac{35}{100}$ acres of land in the county of Natchitoches, on the west side of Red River, about one mile below the town of Natchitoches-bounded East by that part of the River called False River, North and South by land supposed to be vacant, and West by Lake Terre Blanc as it is called. The notice of this claim is accompanied by a plat of survey by a deputy surveyor, dated the 7 th February, 1806, and a certified copy of a deed of sale from John Horn to John Sibley, dated 31st May, 1806; neither of which documents were presented to be filed with the notice of the claim until the 7 th April, 1814. The course of the upper and lower lines of the plat, extending from the river to the lake, appear to have been altered, the one from S. $43^{\circ}$ E. to S. $83^{\circ}$ E. and the other from N. $43^{\circ} \mathrm{W}$. to $\mathrm{N} .83^{\circ} \mathrm{W}$. the last mentioned courses agreeing with those inserted in the deed of sale. A duplicate of the plat being filed in the office of the principal Deputy Surveyor by the said Deputy, is found to correspond with what appears to have been the courses originally set on the lines of the plat filed in the claim, viz. the upper and lower side extending from the River to the Lake are S. $43^{\circ} \mathrm{E}$. and N. $43^{\circ} \mathrm{W}$. Pierre Elie before the Board, the 16 th June, 1812, hath deposed, that the land has been inbabited and cultivated for more than 20 consecutive years. First by Madam Sans Regret and others, claiming un- 
der her to this day : no other evidence has been offered in support of the claim. The evidence of Pierre Elie making it appear that Madam Sans Regret was the original claimant, and there being no document adduced to shew that she had transferred her claim, or by which the nature and extent of the claim as originally held might be ascertained, and the other documents being unsatisfactory, together with the circumstances of there being one claim under an order of survey to John Horn, confirmed, as may appear by Commissioners certificate B. No. 1955; this claim, in the opinion of the Commissioners, ought not to be confirmed, and they report it accordingly.

No. 43. John Sibley claims a lot of land in the Town of Natchitoches, on which he resides, bounded on the South by the river and by the lot on which the church stands, West by a public road or street, and extending back 200 poles. The notice of this claim is accompanied by a certified copy of a deed of sale from Jno. Bte. Ailhand St. Ann to Augustin Le Clerk, dated in 1801, for a lot of ground in the village of Natchitoches, containing half an arpen front on the river. Bounded below by the church lot, above by the large road and in the depth by the gully bordering the hill, which _ represented to have been — of the said St. Ann by purchase from John Lambre, as per deed in the Records of the Post of Natchitoches. $\mathbf{A}$ deed of sale from Louis Beltremeaux, as testamentary executor of the estate of Le Clerk, to John Sibley and Timothy Terrel, dated 8th March, 180S, for said lot with the house on it, and a receipt for the payment, dated 20 th $\mathrm{Fe}$ bruary, 1804; also the release of said Terrel to Sibley in the same year, for all his right and title in said lot and a plat of survey by a Deputy Surveyor, dated in February, 1806, which last document was filed in the claim in April, 1814. Barthelemy Rachel, before the board, the 2sd January, 1812, hath deposed ". That the land claimed has been inhabited and cultivated by the claimant and those uncer whom fie claims, for more than thirty consecutive years immeriately preceding this date." John Ris, on the 18th February, 1813, hath deposed "That the said lot has been inhabited and cultivated for a garden, for more than thirty years immediately preceding this date." The plat of survey filed in the claim not appearing to have marked the gully as a boundary on the back of the lot, conformably to the deed of sale from Ailhand St. Ann, the Commissioners have required a re-survey of this with other lots in the Viliage of Natchitoches; but not having been able to obtain it, on accotint (as the Deputy Surveyor of the district has asserted,) of contentions between adjoining proprietors, this claim is reported as one which, in the opinion of the Commissioners, ought to be confirmed for the quantity which, from a satisfactory survey, shall be found within the proper limits of the lot.

No. 44. John Sibley claims under Francois Mercier and wife, 15 arpens front on the North and 10 arpens front on the opposite side of Red River, with the depth of 40 arpens on each side, say one thousand superficial arpens. The notice of this claim is accompanied by a deed of sale from Louis Mercier and wife to John Sibley, dated 25th day of January, $1800^{\circ}$, for all their right and pretentions to a tract of land 
on which the said Mercier and wife then resided, and on which they had lived for three years then last past, the situation and extent of which tract of land is not set forth in the deed of sale, but reference is had to the certificate of Felix Trudeau of the same date, with the deed, 25th January, 1806, written on the back of the paper containing the deed of sale, and of which certificate the following is a translation in substance. Felix Trudeal, captain of Infantry, heretofore Commandant of Natchitoches for his Majesty, certifies that, in the year 1802, he gave permission to Louis Mercier and his family to settle on a tract of land about the Lake Pauledeau and on the river, bounded above by land of Antoine Poisot, and below by the Bayou and ten arpens on the opposite side." The quantity of land to which Louis Mercier and wife might have set up a claim under the permission of Mr. Trudeau, as above stated, is uncertain, and undetermined, and the evidence of permission is, from having been given since the change of Government, and not under the solemnity of an oath insuficient. No proof to establish occupancy has been adduced, and the claim is therefore reported as one, which, in the opinion of the Commissioners, ought not to be confirmed. The notice is supposed to be erroneous, in claiming under Francois instead of Louis Mercier, whose deed is filed.

No. 45. Nicholas Thibedeau claims six arpens front, by the depth of forty arpens on the east side of the Bayou Teche, county of Attakapas, and twelve arpens superficial on the opposite side of said Bayou, at the prairie Grocherviel, by virtue of a sale from Don Louis de Clouet. The notice is accompanied by deed of sale, from said De Clouet to the claimant, dated $2 \mathrm{~d}$ May, 1796, for a tract of land situate on both sides of the River Teche, at a place called Grand Point, to wit: six arpens front, by the depth of forty arpens on the left or east bank, and twelve superficial arpens, (four arpens front by the depth of three arpens, ) on the right or west bank of the said river; bounded on one side by the land of Jesse E. Lacy, and on the other side by the land of the seller. No proof has been offered to establish occupancy or possession. The commissioners are of opinion, that the deed passed before the commandant, and, duly enregistered, ought to be taken as evidence of the title, and that the claim ought to be confirmed.

No. 46, Widow Oliver Thibedeau, claims ten arpens front by the depth of forty arpens, on the east side of the river Teche, at a place called prairie Grocheveriel, and twenty-one superficial arpens on the west side of said river, county of Attakapas, by virtue of a purchase from Jesse E. Lacy by her deceased husband. The notice of the claim is accompanied by the deed of sale from Chevalier De Slouet, acting for his brother, Louis De Clouet, to Jesse E. Lacy, dated 2d May, 1796 , for ten arpens front by the depth of forty arpens, at a place called Grand Point, on the east bank of the Bayon Teche, adjoining land sold by the same to Pierre Guidry, on one side, and on the other side by land of the seller, and seven arpens front by the depth of three arpens, on the west side of the Teche, descending from a place opposite the boundary of Pierre Guidry. The claimant has produced no evidence of occupancy, nor. does it appear how De Clouet became the 
proprietor of the land. The commissioners are of opinion, however, that the sale executed before the commandant, as early as 1796 , should be taken as evidence that De Clouet had a valid title in the land at that time. This deed being in the possession of, and produced by the claimant, is, at least, strong presumptive evidence of Lacy's having transferred his title, as stated in the notice. The claim is, therefore, reported as one which, in the opinion of the commissioners, ought to be confirmed to the present claimant, conformably to the sale from De Clouet to Lacy.

No, 47. Widow Oliver Thibedeau claims four arpens front by the depth of forty arpens, on the east side of the Bayou Teche, at the prairie Grocherveriel, by virtue of sale from Pierre Broussard, to her deceased husband. Although no original documents of title, nor proof of occupancy has been adduced in this claim, the introduction of an authentic deed of sale, from Pierre Broussard to the deceased husband of the claimant, passed before the proper authority, under the Spanish government, is such evidence of title, as to induce the commissioners to report the claim, as ono which in their opinion ought to be confirmed.

No. 48. Julien Thomas, (widow) claims a tract of land, of seven arpens front by the depth of forty arpens, say 280 superficial arpens, in the prairie of the Hill, county of Opelousas, by virtue of two complete titles, one to Pedro Bourdelon, and the other to and by occupancy and regular conveyance. The notice of this claim is accompanied by a plat of survey, made for Pedro Bourdelon, by the late surveyor, General Carlos Trudeau, for six arpens front by the depth of forty arpens, dated in 1791, and by no other document or evidence of title. Although the claim is unsupported by any evidence of occupancy, and no grant is found in the name of Pedro Bourdelon, on the abstract of complete titles furnished the board, yet, the plat of survey by the surveyor general, under the Spanish government, so early as the year 1791, ought, in the opinion of the commissioners, to be taken as sufficient evidence of title, and the claim confirmed for the land included in the survey. The residue of the claim, to wit : one arpen front by the depth of forty arpens, being unsupported by any evidence of title, cannot be recommended for confirmation.

No. 49. Louis Veillon claims twelve arpens of land front by the depth of forty arpens, in the prairie Grocheveriel, county of Attakapas, by virtue of a purchase from Martin Sondrique. Andre Martin, before the board, the 11th May, 1813, hath deposed, "That the land claimed, is part of Louise and Carline De Clouet's concession, and sold to Martin Sondrique, who inhabited and cultivated the same constantly for twenty years past, aud until he sold the same to Louis Veillon, who continued to have the land inhabited and cultivated to this day." The claimant in his notice, refers to a plat of survey, which is believed to be the same filed in the claim of Pierre Broussard, which appear's to have been made for Martin Sondrique, and for the quantity of land claimed by Viellon. The claim, in the opinion of the commissioners, ought to be confirmed for the land claimed, if found with- 
in the tract conceded to Louise and Carline De Clonet, and on the claimant's producing the transfers necessary to establish his right.

No. 50. Charles Veger claims seven arpens and a-half front, with the depth to the gully, which divides his land from that of Noel Vasseur, and his front line, six arpens and a-half of which front, is part of a survey of fourteen arpens front, made by the late surveyor general, Carlos Trudeau, on a deed of sale, from Chevalier Villier to Francois Fontenot, who sold it to Jn. B'te. Demarais, who sold to the claimant. The residue, to wit: one arpen front, is claimed as part of a tract, granted to Jn. B'te. Figurant. The notice of this claim is accompanied by a plat of survey, by Carlos Trudeau, late surveyor general of the Spanish government, dated in 1794, embracing four arpens front, by the depth of forty, for B'pt. Demarais ; the said surveyor setting forth in his process verbal, that a contestation between Baptiste Demarais and Joseph Andrepont, each baving a concession for the same land, had been settled, by establishing Demarais on four arpens front, and Joseph Andrepont on the residue of the tract. $\boldsymbol{\Lambda}$ deed of conveyance, from Francois Fontenot to Jn. B'te. Demarais, for six and a-half arpens front, with the depth from the gully, which is the limit of the land of Victor Forest, and running _ prairie, called Joseph Forest, _ December, 1801; and also a deed of sale, from Jn. B'te. Demarais to the claimant, for seven and a-half arpens front, dated 4 th January, 1804. No proof to establish occupancy has been taken in the claim. The commissioners are of opinion, that the plat of survey by the surveyor general, filed in the claim, and the deed of transfer from Fontenot to Demarais, which has been regularly passed before the commandant, in the year 1801 , should be taken as sufticient evidence of title, and, therefore, report the claim as one which, in their npinion, ought to be confirmed for the quantity claimed, not exceeding three hundred arpens, equal to seven and a-half arpens front, by the depth of forty arpens, to be ascertained by the survey.

No. 51. Michel Le Villain La Chapelle claims 360 arpens of land on the Bayou Siard, 160 arpens of which he claims under an order of survey to William Dawson, and the remaining 200 arpens by right of settlement. A plat of survey by James McLaughlin, a deputy surveyor under the Spanish Government, dated 26th February, 1801, embracing four arpens and a half front, by the depth of forty arpens on both sides of said Bayou Siard, is filed in the claim, together with the order of survey and deeds of sale to the claimant. By the testimony of James McLaughlin, taken in the claim, it is established that on one side of the Bayou which is prairie land, and held under the order of survey, has been settled and cultivated from the year 1795 , and that the tract on the opposite side of the Bayou is wood land unfit for culture. The claim to 160 arpens, held under the order of survey, has been confirmed by Commissioners' certificate B, No. 416 , leaving the residue, 200 arpens of wood land, the claim to which being unsupported by any document of title, except the plat of survey, and no proof of occupancy, is reported as a claim which, in the opinion of the Commissioners, ought not to be confirmed. 
Signed duplicates, one whereof transmitted to the Commissioner of the General Land Office, in the Treasury Department, the other deposited in the office of the Register of the Land Office at Opelousas.

\section{WM. GARRARD ? \\ LEVIN WAILES, Commissioners. GIDEON FITZ,}

By order of the Board,

Lloyd Posex, Clerk. 